CIVIL ENGINEERING STUDIES

Illinois Center for Transportation Series No. 19-001

UILU-ENG-2019-2001

ISSN: 0197-9191

\title{
SAFETY ANALYSIS AND CRASH MODIFICATION FACTORS OF AN ADAPTIVE SIGNAL CONTROL TECHNOLOGY ALONG A CORRIDOR
}

\author{
Prepared By \\ Jesus Osorio \\ Rahim Benekohal \\ University of Illinois at Urbana-Champaign
}

Research Report No. FHWA-ICT-19-001

A report of the findings of

ICT PROJECT R27-127

Safety and Efficiency Benefits of Implementing Adaptive Signal Control Technology in Illinois

https://doi.org/10.36501/0197-9191/19-001

\section{Illinois Center for Transportation}

January 2019 

TECHNICAL REPORT DOCUMENTATION PAGE

\begin{tabular}{|c|c|c|c|c|c|}
\hline $\begin{array}{l}\text { 1. Report No. } \\
\text { FHWA-ICT-19-001 }\end{array}$ & \multicolumn{2}{|c|}{$\begin{array}{l}\text { 2. Government Accession No. } \\
\text { N/A }\end{array}$} & \multicolumn{3}{|c|}{$\begin{array}{l}\text { 3. Recipient's Catalog No. } \\
\text { N/A }\end{array}$} \\
\hline \multirow{2}{*}{\multicolumn{3}{|c|}{$\begin{array}{l}\text { 4. Title and Subtitle } \\
\text { Safety Analysis and Crash Modification Factors of an Adaptive Signal Control } \\
\text { Technology along a Corridor }\end{array}$}} & \multicolumn{3}{|c|}{$\begin{array}{l}\text { 5. Report Date } \\
\text { January } 2019\end{array}$} \\
\hline & & & \multicolumn{3}{|c|}{$\begin{array}{l}\text { 6. Performing Organization Code } \\
\text { N/A }\end{array}$} \\
\hline \multicolumn{3}{|c|}{$\begin{array}{l}\text { 7. Author(s) } \\
\text { Jesus J. Osorio and Rahim (Ray) F. Benekohal }\end{array}$} & \multicolumn{3}{|c|}{$\begin{array}{l}\text { 8. Performing Organization Report No. } \\
\text { ICT-19-001 } \\
\text { UILU-ENG-2019-2001 }\end{array}$} \\
\hline \multicolumn{3}{|c|}{ 9. Performing Organization Name and Address } & \multicolumn{3}{|c|}{$\begin{array}{l}\text { 10. Work Unit No. } \\
\text { N/A }\end{array}$} \\
\hline $\begin{array}{l}\text { Department of Civil and Environmen } \\
\text { University of Illinois at Urbana-Cham } \\
205 \text { North Mathews Avenue, MC-25 } \\
\text { Urbana, IL } 61801\end{array}$ & eering & & $\begin{array}{l}11 . \\
\mathrm{R} 2\end{array}$ & $\begin{array}{l}\text { Contract or Grant I } \\
127\end{array}$ & \\
\hline \multirow{2}{*}{\multicolumn{3}{|c|}{$\begin{array}{l}\text { 12. Sponsoring Agency Name and } \\
\text { Illinois Department of Transportati } \\
\text { Bureau of Research } \\
126 \text { East Ash Street } \\
\text { Springfield, IL } 62704\end{array}$}} & \multicolumn{3}{|c|}{$\begin{array}{l}\text { 13. Type of Report and Period Covered } \\
\text { Safety Report } \\
1 / 1 / 13-12 / 1 / 18\end{array}$} \\
\hline & & & \multicolumn{3}{|c|}{ 14. Sponsoring Agency Code } \\
\hline \multicolumn{6}{|c|}{$\begin{array}{l}\text { 15. Supplementary Notes } \\
\text { Conducted in cooperation with the U.S. Department of Transportation, Federal Highway Administration. } \\
\text { https://doi.org/10.36501/0197-9191/19-001 }\end{array}$} \\
\hline \multicolumn{6}{|c|}{$\begin{array}{l}\text { 16. Abstract } \\
\text { The main objective of this study is to determine the safety effectiveness of the adaptive signal control technology (ASCT) } \\
\text { SynchroGreen using an observational before and after study applying the Empirical Bayes (EB) method. Both national (HSM) and } \\
\text { state specific (Illinois) safety performance functions (SPF) were selected and calibrated for the local conditions. A total of } 14 \text { SPFs } \\
\text { from the HSM and } 3 \text { additional from Illinois were calibrated and crash modification factors (CMF) were developed. For multiple- } \\
\text { vehicle fatal and injury (FI) crashes at all intersections (four-legged and three-legged combined), the CMF was } 0.67 \text {, which was } \\
\text { not statistically significant at } 95 \text { percent confidence level (it was significant at } 87 \text { percent). For four-legged-only intersections the } \\
\text { CMF was } 0.67 \text { as well, which was not significant with } 95 \text { percent confidence (it was significant at } 85 \text { percent). The } 87 \text { and } 85 \\
\text { percent are not confidence levels used in practice, however they clearly indicate a decreasing trend in FI crashes due to the } \\
\text { implementation of ASCT. For PDO and total crashes, all CMF computed were very close to one indicating no crash reduction due } \\
\text { to the implementation of ASCT. The CMF for Illinois KAB crashes (fatal, type A injury, and type B injury crashes combined) was } \\
\text { found to be } 0.68, \text { which was not significant at } 95 \text { percent confidence level (it was significant at } 71 \text { percent indicating a decreasing } \\
\text { trend in these types of crashes). Paired t-test results showed no reduction in sideswipe same direction, turning, and type B injury } \\
\text { crashes. However, angle, rear end, type A and type C injury crashes showed slight decreases that were not significant. }\end{array}$} \\
\hline \multicolumn{2}{|c|}{$\begin{array}{l}\text { 17. Key Words } \\
\text { Crash Modification Factor, Safety Performance Functions, Highway } \\
\text { Safety Manual, Adaptive Signal Control Technology, SynchroGreen }\end{array}$} & \multicolumn{4}{|c|}{$\begin{array}{l}\text { 18. Distribution Statement } \\
\text { No restrictions. This document is available through the } \\
\text { National Technical Information Service, Springfield, VA } \\
22161 .\end{array}$} \\
\hline $\begin{array}{l}\text { 19. Security Classif. (of this report) } \\
\text { Unclassified }\end{array}$ & \multicolumn{3}{|c|}{$\begin{array}{l}\text { 20. Security Classif. (of this page) } \\
\text { Unclassified }\end{array}$} & $\begin{array}{l}\text { 21. No. of Pages } \\
38+\text { appendices }\end{array}$ & $\begin{array}{l}\text { 22. Price } \\
\text { N/A }\end{array}$ \\
\hline
\end{tabular}

Form DOT F 1700.7 (8-72)

Reproduction of completed page authorized 



\section{ACKNOWLEDGMENT, DISCLAIMER, MANUFACTURERS' NAMES}

This publication is based on the results of ICT-R27-127, Safety and Efficiency Benefits of Implementing Adaptive Signal Control Technology in Illinois. ICT-R27-127 was conducted in cooperation with the Illinois Center for Transportation; the Illinois Department of Transportation; and the U.S. Department of Transportation, Federal Highway Administration.

Members of the Technical Review panel were the following:

- Kyle Armstrong, TRP Chair - IDOT Bureau of Operations

- Gary Sims - IDOT District 5

- $\quad$ Dave Burkybile - IDOT District 5

- $\quad$ Eric Howald - IDOT District 4

- Mike Irwin - IDOT District 6

- $\quad$ Kristen Micheff - IDOT District 1

- Jon Nelson - Lake County Division of Transportation

- Dean Mentjes - FHWA IL Division

- Jon McCormick - IDOT Bureau of Safety Programs and Engineering

- Tim Peters - IDOT Bureau of Local Roads and Streets

The contents of this report reflect the view of the author(s), who is (are) responsible for the facts and the accuracy of the data presented herein. The contents do not necessarily reflect the official views or policies of the Illinois Center for Transportation, the Illinois Department of Transportation, or the Federal Highway Administration. This report does not constitute a standard, specification, or regulation.

Trademark or manufacturers' names appear in this report only because they are considered essential to the object of this document and do not constitute an endorsement of product by the Federal Highway Administration, the Illinois Department of Transportation, or the Illinois Center for Transportation. 


\section{EXECUTIVE SUMMARY}

The main objective of this study was to determine the safety effectiveness of the adaptive signal control technology (ASCT) SynchroGreen using an observational before and after study applying the Empirical Bayes (EB) method. SynchroGreen was installed at six intersections along the Neil Street corridor in Champaign, IL. Five of the intersections were four-legged intersections and one was a three-legged intersection. Both national (Highway Safety Manual) and state specific (Illinois) Safety performance functions (SPFs) were selected and calibrated for the local conditions for the study period 2012-2016. Crash data for 2012-2014 was used for the "before" conditions, and the data for May 2015-Oct 2016 was used for the "after" conditions. A total of 14 SPFs from the Highway Safety Manual (HSM) and 3 additional from Illinois were calibrated and crash modification factors (CMF) were developed. CMFs were developed for each crash severity and type.

For multiple-vehicle FI crashes at all intersections (four-legged and three-legged combined), the CMF was 0.67 , which was not statistically significant at 95 percent confidence level (it was significant at 87 percent). For four-legged-only intersections the CMF was 0.67 as well, which was not significant at 95 percent confidence level (it was significant at 87 percent). The 87 and 85 percent are not confidence levels used in practice, however they clearly indicate a decreasing trend in FI crashes due to the implementation of ASCT. However, for the three-legged intersection, there was not adequate data to develop CMFs. For PDO and total crashes, all CMFs computed were close to one indicating no crash reduction due to the implementation of ASCT. The above findings are based on SPFs from HSM which were chosen over previously developed SPFs for Illinois. Nonetheless, the CMF for Illinois KAB (fatal, type $A$ injury, and type $B$ injury crashes combined) crashes was computed and found to be 0.68 , which was not significant at 95 percent confidence level (it was at 71 percent indicating a decreasing trend in these types of crashes).

Wilcoxon Signed Ranked tests were performed. However, due to a small sample size, they were not relied on for assessing if there was a shift in the location of crashes. For this reason, paired t-tests were performed to further explore which crashes were most affected by the reduction due to the ASCT implementation.

The results from the paired tests show decreasing trends in crash type and severity as well as no change on two crash types and no change in severity of type B crashes. For the angle and rear end crashes it showed reductions, but they were not found to be statistically significant. For sideswipe same direction and turning crashes it showed no change. From the crash severities, Type A injury and Type $C$ injury crashes showed a reduction but was not found to be statistically significant.

The assumption of medium level pedestrian volume for mid-sized cities was supported using local data (727 pedestrians per day using local data is very close to the medium level of 700 pedestrians per day in HSM).

It was recommended to further study the ASCT's long-term (multi-year) safety effects. Also, to study the effects of ASCT on three-legged intersections additional field data is needed. 


\section{CONTENTS}

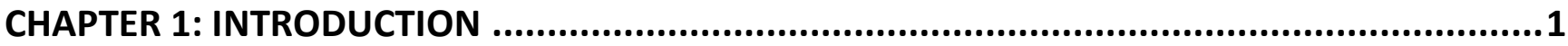

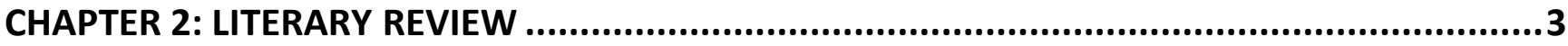

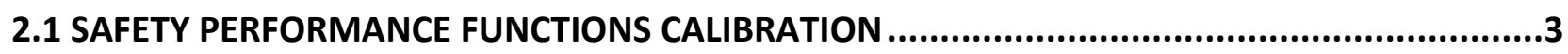

2.2 CRASH MODIFICATION FACTOR FOR ADAPTIVE SIGNAL CONTROL TECHNOLOGY..................4

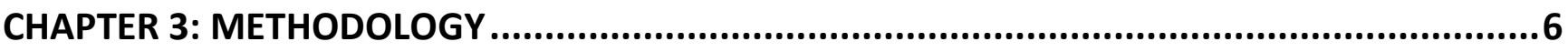

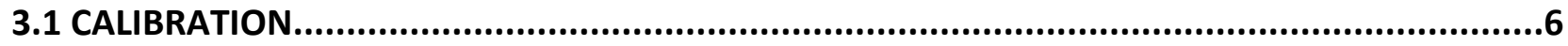

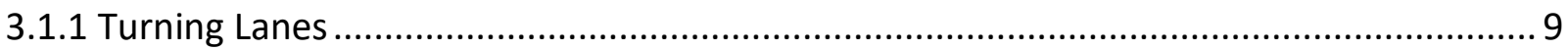

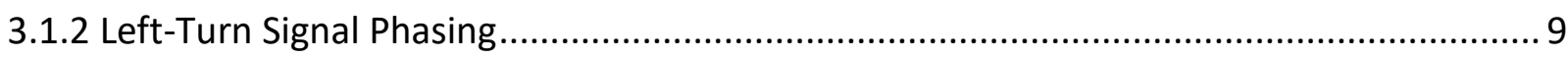

3.1.3 Right Turn on Red ............................................................................................. 10

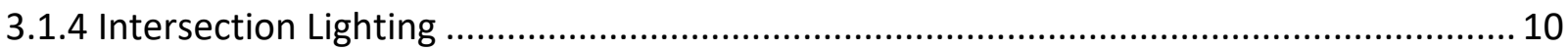

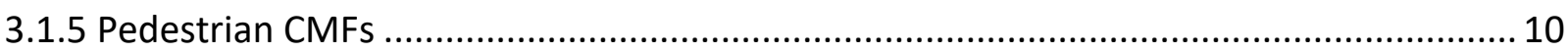

3.1.6 Goodness of Fit ......................................................................................................... 10

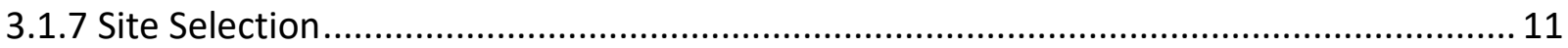

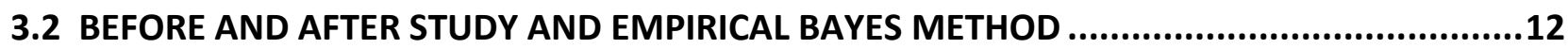

3.3 Shift in Proportions …………………............................................................................ 13

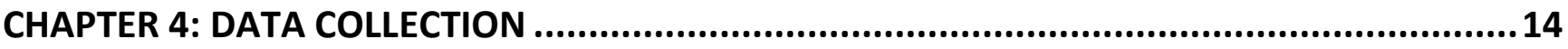

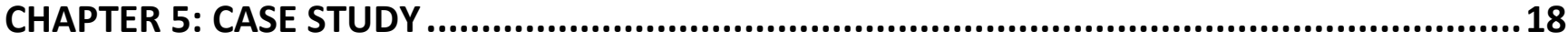

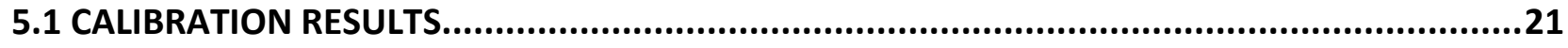

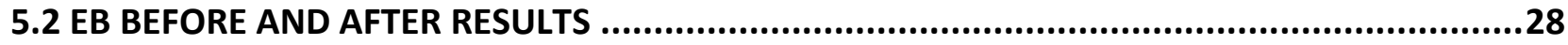

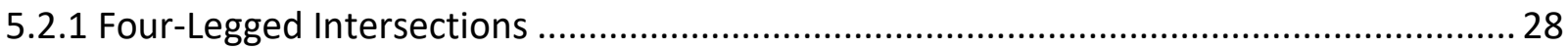

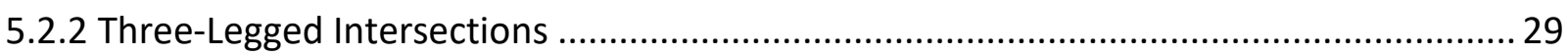

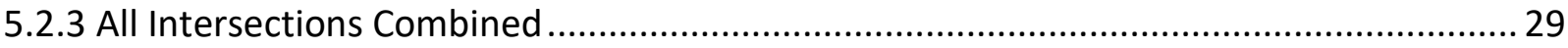

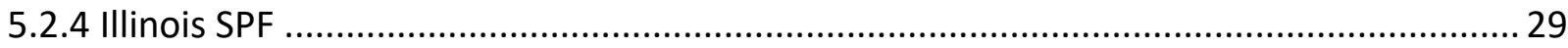

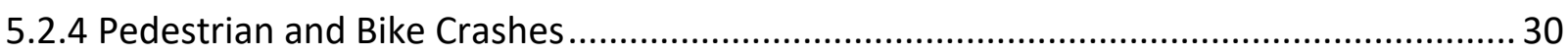

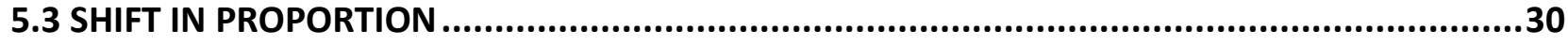

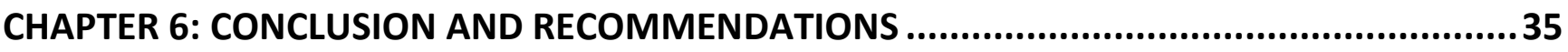

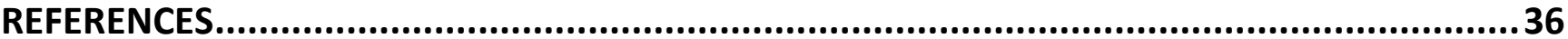




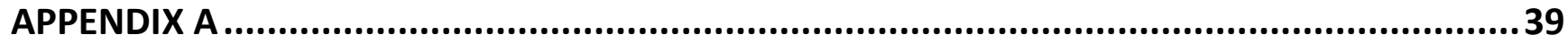

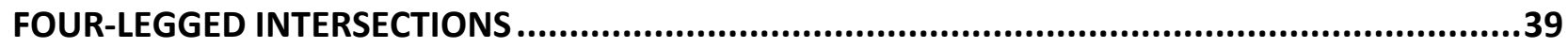

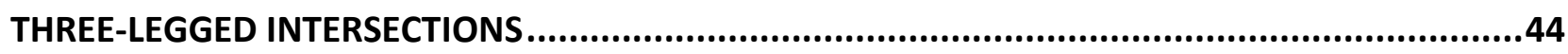

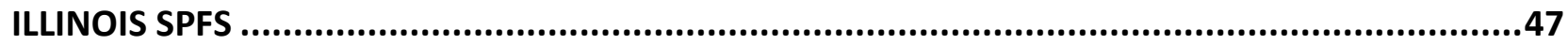

APPENDIX B

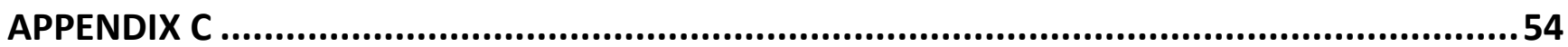

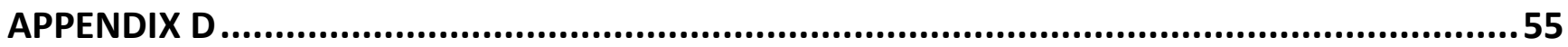




\section{CHAPTER 1: INTRODUCTION}

Adaptive Signal Control Technologies (ASCT) continuously adjusts traffic signal timings to accommodate real-time changes in traffic demand to improve traffic operation efficiency and safety. Although many studies have been performed to evaluate the efficiency benefits of ASCT (Benekohal et al. 2018; Rawoof et al. 2017; Cheek et al. 2012; So et al. 2014; Trafficware 2012; Trafficware Baytown; Trafficware Galveston; Trafficware Brevard), few (Funk et al. 2016; Khattak et al. 2018; Ma et al. 2016; Stevanovic et al. 2011) have primarily focused on quantifying the safety effects of this technology. The Illinois Department of Transportation (IDOT) is interested in the operational efficiency and safety evaluation of the ASCT. There are a variety of ASCT systems, but the one that was selected through a competitive bidding process was SynchroGreen, which is an ASCT system from Trafficware Inc. (Trafficware 2012).

This study fills the gap by developing CMFs with data collected by deploying SynchroGreen. Studies in the past have evaluated the operational efficiency of SynchroGreen, but there is a lack of safety analysis of this system in the literature. This study also applies the EB method with two different sets of Safety Performance Functions (SPF): The Highway Safety Manual (HSM) and the state specific SPFs and compares the results accordingly. Additionally, local pedestrian volumes are considered when calibrating the pedestrian SPFs from the HSM.

The main objective of this report is to determine the safety effectiveness of the ASCT system using an observational before and after study applying the Empirical Bayes (EB) method. SynchroGreen was installed along the Neil Street corridor in Champaign, IL. Both national (Highway Safety Manual) and state specific (Illinois) SPFs were selected and calibrated for the local conditions. A total of 14 SPFs from the HSM and 3 additional from Illinois were calibrated and crash modification factors (CMF) were developed. The HSM SPFs are divided into single and multiple-vehicle crashes, which in turn are divided into total, fatal and injury (FI) and property damage only (PDO) crashes. The HSM SPFs also include pedestrian models for three and four-legged intersections. On the other hand, the Illinois SPFs are divided into type $A$ injury crashes, type $B$ injury crashes, and KAB (fatal, type $A$, and type $B$ combined) crashes. The Illinois models do not differentiate among three and four-legged intersections or single and multiple-vehicle crashes.

The study also examined the shift in crash proportion. A Wilcoxon Signed-Rank test was performed to determine if there existed a statistically significant shift in the crash severity (type A injury, type $B$ injury, type $C$ injury crashes) and crash type (angle, rear end, sideswipe same direction, and turning crashes). A paired t-test was also performed to evaluate the change in crash frequencies for the same types and severities.

The document is structured in the following way: Chapter 2 gives background of past studies which deal with SPF calibration and studies that have studied the safety of ASCT. Chapter 3 provides the methodology for the calibration of SPF and CMF computations. Chapter 4 describes the data collection procedures applied in this project. Chapter 5 describes the specific project site studied and 
the results from the analysis. Chapter 6 provides the conclusion and the appendices contain raw data and plots utilized throughout the study. 


\section{CHAPTER 2: LITERARY REVIEW}

\subsection{SAFETY PERFORMANCE FUNCTIONS CALIBRATION}

Since the publication of the first edition of the HSM (AASHTO 2010), many efforts have been made to calibrate SPF for local conditions. This allows agencies to perform safety analysis more accurately since instead of using nationwide values, they apply values to their specific state or condition of interest. Many states (listed below) have performed local calibrations for all SPF and have also developed their own local SPFs: Florida (Srinivasan et al. 2011) which calibrated the SPF for all facility types for the period of 2005-2008; Oregon (Xie et al. 2011) also made a statewide calibration for all facilities from 2004 to 2006; The state of Maryland (Shin, 2014) calibrated the HSM models for the years of 2008 to 2010, and also targeted all roadway segments and intersection types; Missouri (Sin et al., 2013) calibrated both rural and urban intersections as well as freeway segments and highway segments SPFs for the years of 2009 to 2011. Other states have also performed calibration to specific models such as Massachusetts (Xie and Chen 2016), which focused their calibration on urban and suburban intersections. Further information on calibration efforts can be found in the Summary of State SPF Calibration and Development Effort document on the Crash Modification Factor Clearinghouse website (FHWA 2016).

Regarding the SPF calibration procedures, the User's Guide to Develop Highway Safety Manual Safety Performance Function Calibration Factors (Bahar 2014) focuses on Part C predictive method of the HSM (Predictive Method for rural two-lane, two-way roads; rural multilane highways; and urban and suburban arterials). Part C of the HSM is used to estimate expected average crash frequencies on specific sites or a combination of sites. The predictive method combines predicted crash frequencies with observed crash frequencies to improve the overall prediction of expected crashes on a given project. This report fills the gaps by approaching many questions regarding the calibration process which are not explained in depth in the HSM (AASHTO 2010). In addition to clearly outlining the calibration protocols, Bahar provides guidelines to answer common questions within engineering practice such as the level of accuracy desired in the prediction, or the number of sites required for a desired accuracy in the prediction. Bahar also provides guidelines on when to develop separate calibration factors for specific conditions (e.g. mountainous areas vs plain areas).

In 2015, Hauer published The Art of Regression Modeling in Road Safety in which he outlines procedures to develop multivariate statistical models, and to assess the accuracy of predictions made by such models. He highlighted the idea of applying cumulative residual (CURE) plots to assess the existence of a possible bias and overall accuracy in the predictions. This method of assessing the accuracy of estimation provides a more comprehensive assessment of the SPF performance than the usual single-number measure such as chi-squared coefficients or $\mathrm{R}^{2}$. CURE plots help to assess the performance of the SPF by giving the modeler clues of how well the model performs and are now widely used for calibration assessments.

More recently, the tool The Calibrator (Lyon et al. 2016) was released. This analytical tool helps researchers in the calibration process by taking care of all the computational steps required for 
calibration once the safety data has been extracted and formatted. The tool helps researchers develop CURE plots and is loaded with all the SPFs in the HSM for analysis of all facility types. The report includes several ways to assess the quality of calibration such as mean absolute deviation, modified r-squared, dispersion parameters coefficient of variation, and the aforementioned CURE plots.

\subsection{CRASH MODIFICATION FACTOR FOR ADAPTIVE SIGNAL CONTROL TECHNOLOGY}

There exists limited literature in quantifying the safety effects of ASCT through the development of CMFs or through other statistical analyses. Studies in the past have mainly focused on evaluating the operational performance of ASCT and have speculated the safety effects. Nonetheless, in recent years, more focus has been directed towards the quantification of safety after the HSM (AASHTO 2010) provided guidelines and analytical tools on how to study the safety data available.

In the past, Hicks and Carter claimed that "A reduction in number of stops leads to reduced chance of rear-end collisions" (2000). They studied the delay reduction for Sydney Coordinated Adaptive Traffic Systems (SCATS) and reported from system deployments in Florida, Michigan, and California that the SCATS system reduced the stops from 28 percent to 41 percent compared to fully the optimized fixed-time systems.

Dutta et al. (2010) studied the safety effects of SCATS by deploying the system to 9 intersections and performing a before and after analysis by statistically comparing the before period of 1999-2001 to the after period of years 2003-2008 applying the t-test. Researchers did not observe a statistically different quantity of total crashes at 95 percent confidence level, but they observed a shift in crash severity from types $A$ and $B$ to $C$.

Lodes and Benekohal (2013) studied the safety benefits of ASCT with very limited data from a survey sent to 62 agencies. They evaluated three intersections with one year of before and after conditions, and only considered the total number of crashes. Their data shows that there is a potential safety benefit from deploying ASCT, but the data was not enough to conduct a statistically significant analysis.

Ma et al. (2016) performed a before and after study with the Empirical Bayes (EB) approach in the state of Virginia. Researchers studied 10 corridors containing a total of 9 three-legged and 38 fourlegged intersections and determined crash modification factors (CMFs) for both intersection types. The study compared five years of before data to one year of after data. Ma et al. determined that the only CMF statistically significant at 95 percent confidence level was equal to 0.79 for total four-leg intersection crashes. It is worth mentioning that the system they deployed was InSync, and they claimed these results might not be transferrable to other systems but could still provide insights on the safety performance of ASCT overall.

Fink et al. (2016) performed a cross sectional study with 498 intersections with SCATS-based systems in Oakland County, MI. The study found that the system is likely to reduce angle crashes by 19.3 percent and increase the non-serious injury crashes by developing and applying negative binomial 
and multinomial logit models. The study also found a statistically significant increase in type B injuries and no significant reduction in $\mathrm{K}$ and $\mathrm{A}$ injuries.

Other studies have used surrogate methods to study the safety of ASCT. Stevanovic et al. (2013) studied the safety performance of adaptive signals by means of microsimulation environments. Researchers built a microsimulation model with VISSIM software based on extensive field data, then it was calibrated and validated based a $11.8 \mathrm{~km}$-long corridor along the route located in Park City, Utah. It was found that SCATS reduced the total number of conflicts by more than 11 percent compared to traditional time of the day (TOD) signals. Additionally, during the study period, an increase of field crashes was observed, but researchers claimed that this might be due to the construction activities happening around the corridor during the study period (2007-2008) and not merely because of the ASCT performance.

More recently, Khattak et al. (2018) computed CMFs for ASCT by applying the before and after EB method to 41 intersections in Pennsylvania. The 41 intersections were split into 9 in which InSync was deployed and 32 in which Scalable Urban Traffic Control (SURTRAC) was deployed. The study found statistically significant CMFs at a 95 percent confidence level over all intersections and systems of 0.87 for total crashes and 0.64 for fatal and injury (FI) crashes. Furthermore, the CMFs for InSync alone were 0.86 and 0.66 , while the CMFs computed for intersections with SURTRAC were 0.89 and 0.60 for total and $\mathrm{FI}$ crashes respectively. These results follow the same trend as the ones found by Ma et al. (2016) who found a CMF of for total four-legged intersection crashes of 0.79 . 


\section{CHAPTER 3: METHODOLOGY}

To apply a before and after EB method, the study requires the selection and calibration of SPFs to compute the CMFs for the project. Two sets of SPFs were considered, the ones provided by AASHTO in the first edition of the HSM (2010), and the ones developed for Illinois (Tegge et al. 2010). Since this study is about intersections in which ASCT was installed, the SPFs compared and evaluated were those related to urban signalized intersections.

Tegge et al. (2010) developed four different SPFs for urban signalized intersections: SPF for fatal crashes (i.e. type K), type A injury crashes, type B injury crashes, and FI crashes together excluding type $\mathrm{C}$ crashes (For now on, the Illinois FI crashes will be referred as KAB SPF). These models were developed using 5 years of data from Illinois, and they estimate crash frequency for 5 -year period. One of the limitations of their datasets was "the inability to recognize the number of legs at intersections" (Tegge et al. 2010). Thus, their models do not differentiate between three and fourlegged intersections or single and multiple-vehicle crashes. Another limitation is that they do not estimate the property-damage-only (PDO) crashes, which usually represent a significant proportion of the total crashes. Additionally, the base conditions for the intersections for which the Illinois SPF were developed are unclear as for instance the number of lanes or the type of left-turn signal phasing.

On the other hand, the models provided by the HSM are more specific models that divide the number of vehicles involved in the crash to multiple and single-vehicle crashes, categorizes the crash severity into $\mathrm{Fl}$, and PDO crashes, and then distinguishes the models for three-legged from the four-legged signalized intersections models. Thus, there is a total of 12 models for vehicular traffic plus two models to estimate pedestrian crash frequencies. Each of the 14 models provides single-year estimates. The models also clearly outline the base condition of intersections, and provide CMFs to adjust the models in case intersections differ from the SPF's base condition. Details about the base conditions and CMF applied in the calibration can be found In Section 3.1.7.

The calibration was performed for all 14 models from the HSM and results are discussed in section 5.1. The Illinois SPFs were also calibrated for comparison purposes, but since Tegge et al. (2010) did not develop specific SPFs for three and four-legged intersections, the datasets for three and fourlegged intersections were combined to make a corresponding calibration.

\subsection{CALIBRATION}

To calibrate the urban intersection SPF, the HSM recommends that for determining the local calibration factors a minimum of 30 to 50 sites of each facility type containing 100 or more crashes per year be used. Nonetheless, studies have pointed out that this one-size-fits-all recommendation may not be enough for calibrations because it was not based on statistical evidence (Bahar 2014; Shirazi et al. 2016; Alluri et al. 2016). In this study it was decided that larger sample sizes were needed to obtain more reliable results. Thus, a total of 199 total sites (intersections) from four different cities in Illinois (champaign-Urbana, Bloominton-Normal, Springfield, and Peoria) were used in the calibration. Details on the site selection can be found in section 3.1.7. 
To compute the calibration factor, the ratio of the total number of crashes observed in the study period to the total number of crashes predicted by the models in the same time period is calculated, as shown in Equation 1. The number of predicted crashes was determined by the general Equations 2 and 3 shown below for each crash severity, type and facility. Table 1 shows the specific SPF utilized from the HSM and Table 2 presents the Illinois specific SPFs.

$$
\begin{gathered}
\mathrm{C}=\frac{\sum N_{\text {observed }}}{\sum N_{\text {predicted }}} \\
\mathrm{N}_{\text {predicted }}=\mathrm{N}_{\mathrm{spf}} *\left(\mathrm{CMF}_{1} * \mathrm{CMF}_{2} * \ldots \mathrm{CMF}_{6}\right) * C \\
\mathrm{~N}_{s p f}=\exp \left(a+b * \ln \left(A A D T_{\text {maj }}\right)+c * \ln \left(A A D T_{\text {min }}\right)\right)
\end{gathered}
$$

Where,

$\mathrm{N}_{\mathrm{spf}}=$ number of crashes predicted by the uncalibrated model for the intersection base conditions; $A A D T_{\text {maj }}=$ Annual Average Daily Traffic $(A A D T)$ of the intersection major road; $A A D T_{\text {min }}=A A D T$ of the intersection minor road; $a, b$, and $c=$ regression coefficients; $\mathrm{CMF}_{\mathrm{i}}=$ crash modification factor for condition $\mathrm{i} ; \mathrm{C}=$ local calibration factor; $\mathrm{N}_{\text {observed }}=$ number of crashes observed on the field; and $\mathrm{N}$. predicted $=$ number of crashes predicted by the calibrated model.

Table 1. HSM's SPFs for Each Facility Type, Crash Type, and Severity

\begin{tabular}{|c|c|c|c|c|c|c|}
\hline $\begin{array}{c}\text { Intersection } \\
\text { type }\end{array}$ & Crash type & Crash severity & $\begin{array}{c}\text { Intercept } \\
(\mathbf{a})\end{array}$ & $\begin{array}{c}\text { AADT }_{\text {maj }} \\
(\mathbf{b})\end{array}$ & $\begin{array}{c}\text { AADT }_{\text {min }} \\
\text { (c) }\end{array}$ & $\begin{array}{c}\text { Overdispersion } \\
\text { Parameter (k) }\end{array}$ \\
\hline \multirow{5}{*}{$45 G$} & Multiple-Vehicle & Total & -10.99 & -1.07 & 0.23 & 0.39 \\
\cline { 2 - 7 } & Multiple-Vehicle & FI & -13.14 & 1.18 & 0.22 & 0.33 \\
\cline { 2 - 7 } & Multiple-Vehicle & PDO & -11.02 & 1.02 & 0.24 & 0.44 \\
\cline { 2 - 7 } & Single-Vehicle & Total & -10.21 & 0.68 & 0.27 & 0.36 \\
\cline { 2 - 7 } & Single-Vehicle & FI & -9.25 & 0.43 & 0.29 & 0.09 \\
\cline { 2 - 7 } & Single-Vehicle & PDO & -11.34 & 0.78 & 0.25 & 0.44 \\
\hline \multirow{4}{*}{$3 S G$} & Multiple-Vehicle & Total & -12.13 & 1.11 & 0.26 & 0.33 \\
\cline { 2 - 7 } & Multiple-Vehicle & FI & -11.58 & 1.02 & 0.17 & 0.30 \\
\cline { 2 - 7 } & Multiple-Vehicle & PDO & -13.24 & 1.14 & 0.3 & 0.36 \\
\cline { 2 - 7 } & Single-Vehicle & Total & -9.02 & 0.42 & 0.4 & 0.36 \\
\cline { 2 - 7 } & Single-Vehicle & FI & -9.75 & 0.27 & 0.51 & 0.24 \\
\cline { 2 - 7 } & Single-Vehicle & PDO & -9.08 & 0.45 & 0.33 & 0.53 \\
\hline
\end{tabular}


Table 2. Illinois Specific SPFs for Urban Signalized Intersections (Tegge et al. 2010)

\begin{tabular}{|c|c|c|c|c|}
\hline Crash severity & $\begin{array}{c}\text { Intercept } \\
\text { (a) }\end{array}$ & $\begin{array}{c}\mathbf{A A D T}_{\text {maj }} \\
\text { (b) }\end{array}$ & $\begin{array}{c}\text { AADT }_{\text {min }} \\
\text { (c) }\end{array}$ & $\begin{array}{c}\text { Overdispersion } \\
\text { Parameter (k) }\end{array}$ \\
\hline KAB & -8.248 & 0.793 & 0.252 & 0.664 \\
\hline Type A Injury & -9.384 & 0.765 & 0.259 & 0.695 \\
\hline Type B Injury & -8.661 & 0.801 & 0.254 & 0.649 \\
\hline Fatal & -13.380 & 0.890 & 0.213 & 1.000 \\
\hline
\end{tabular}

For pedestrian Crashes the SPF was provided in the form of Equation 4 below, and Table 3 presents the coefficient values utilized taken from the HSM (2010).

$$
N_{\text {ped }}=\exp \left(a+b * \ln \left(A A D T_{\text {total }}\right)+c * \ln \left(\frac{A A D T_{\min }}{A A D T_{\text {maj }}}\right)+d * \ln (\text { PedVol })+e * n_{\text {lanesx }}\right)
$$

Where,

$A A D T_{\text {total }}=$ The sum of the AADT volumes for both major and minor roads; PedVol = sum of daily pedestrian volumes (pedestrian/day) crossing all intersection legs; $n_{\text {lanesx }}=$ maximum number of traffic lanes crossed by a pedestrian in any crossing maneuver at the intersection; and a, b, $c$, and d= regression coefficients.

Table 3. Pedestrian SPFs for Signalized Intersections

\begin{tabular}{|c|c|c|c|c|c|c|}
\hline $\begin{array}{c}\text { Intersection } \\
\text { type }\end{array}$ & $\begin{array}{c}\text { Intercept } \\
\text { (a) }\end{array}$ & $\begin{array}{c}\text { AADT }_{\text {total }} \\
\text { (b) }\end{array}$ & $\begin{array}{c}\text { AADT }_{\text {min }} / \text { AADT }_{\text {maj }} \\
\text { (c) }\end{array}$ & $\begin{array}{c}\text { PedVol } \\
\text { (d) }\end{array}$ & $\begin{array}{c}\mathbf{n}_{\text {lanesx }} \\
\text { (e) }\end{array}$ & $\begin{array}{c}\text { Overdispersion } \\
\text { Parameter (k) }\end{array}$ \\
\hline 3SG & -6.60 & 0.05 & 0.24 & 0.41 & 0.09 & 0.52 \\
\hline 4SG & -9.53 & 0.40 & 0.26 & 0.45 & 0.04 & 0.24 \\
\hline
\end{tabular}

Lastly, for bike crashes the HSM recommends to develop a local factor, $f_{\text {bike }}$ which represents the proportion of bike crashes to the total number of crashes and multiply it by SPF for total crashes. The number of vehicle bicycle collisions per year for an intersection is estimated with Equation 5.

$$
N_{\text {bike }}=N_{\text {total }} * f_{\text {bike }}
$$

Where $\mathrm{N}_{\text {total }}$ is the predicted number of total crashes per year excluding pedestrian and bicycle crashes applying values in Table 1 , and $f_{\text {bike }}$ is the computed ratio of bicycle crashes to total crashes.

Equation 2 shows the application of CMFs to calculate the number of predicted crashes. These CMFs are applied to modify the prediction of crashes for intersections which do not share the base conditions with the original intersections for which the model was created. In this study, the CMFs were only applied to the HSM models. The base condition for three and four-leggged signalized intersections used in developing the HSM models are the following:

- Absence of left-turn lanes 
- Permissive left-turn signal phasing

- Absence of right-turn lanes

- Right turn on red is permitted

- Absence of lighting at intersection

- Absence of red-light cameras

- Absence of bus stops within $1000 \mathrm{ft}$ of the intersection

- Absence of schools within $1000 \mathrm{ft}$ of the intersection

- Absence of alcohol sales establishment within $1000 \mathrm{ft}$ of the intersection

In the calibration process, each characteristic is assigned a CMF which represents such condition. For instance, if the intersection does not have left-turn lanes, then the CMF would be equal to 1 because it agrees with the base condition. On the other hand, if the intersection has left-turn lanes, the CMF is different according to the expected effect of left-turn lanes on crash frequencies. If the CMF is greater than one, then the intersection with the characteristic associated with that CMF is expected to experience more crashes relative to the base condition. Similarly, if the CMF is less than one, the intersection with the characteristic associated with that CMF is expected to experience less crashes relative to the base condition. The CMFs applied in this study are described below.

\subsubsection{Turning Lanes}

The HSM provides two tables for the values of the CMF in the presence of right and left-turn lanes. The specific CMF values are presented in Table 4. Each CMF has to be raised to the power of $n$, where $\mathrm{n}$ is the number of approaches containing the type of lane represented by the CMF.

Table 4. CMF for Left and Right Turning Lanes

\begin{tabular}{|c|c|c|}
\hline Number of Legs & Lane & Value \\
\hline Three & Right turn & $0.96^{n}$ \\
\hline Three & Left turn & $0.93^{n}$ \\
\hline Four & Right turn & $0.96^{n}$ \\
\hline Four & Left turn & $0.90^{n}$ \\
\hline
\end{tabular}

\subsubsection{Left-Turn Signal Phasing}

The HSM also provides tables for type of signal phasing. Similar to the turn lanes, the CMF is a function of the number of approaches with a particular type of signal phasing. The different values for protected only and permissive/protected signal phasing are the following:

- $\quad$ Protected only $\mathrm{CMF}=0.94^{\mathrm{n}}$

- Permissive/protected $\mathrm{CMF}=0.99^{\mathrm{n}}$ 


\subsubsection{Right Turn on Red}

If the intersection contains a right-turn-on-red-prohibited sign, the value of the CMF is equal to $0.98^{n}$ where $\mathrm{n}$ is the number of approaches where the sign is present.

\subsubsection{Intersection Lighting}

For the SPFs found in the HSM, the base condition does not include lighting at intersections. The formula for determining the $\mathrm{CMF}$ is the following:

$$
\mathrm{CMF}=1-0.38 *\left(p_{n i}\right)
$$

Where $p_{n i}$ is the proportion of total crashes for unlighted intersections that occur at night.

Unfortunately, the data utilized in this project did not include unlighted intersections, so the $\mathrm{p}_{\mathrm{ni}}$ could not be updated for local conditions. Therefore, the tabulated value of 0.235 provided by the HSM was assumed for all intersections (AASHTO 2010)

Finally, red-light cameras CMF was not taken into account because none of the intersections in the before and after study, or the calibration process contained red-light cameras.

\subsubsection{Pedestrian CMFs}

The three CMFs applied for the pedestrian models are very similar. They depend on whether or not schools, bus stops, or alcohol sales establishments are within $1000 \mathrm{ft}$ of the intersection. Depending on the amount of each type of building in that 1000 - $\mathrm{ft}$ radius, the CMFs take different values as shown in Table 5 below.

Table 5. Pedestrian CMF According to Facilities Within $1000 \mathrm{ft}$ of Intersection

\begin{tabular}{|c|c|c|}
\hline Facility & Number & CMF \\
\hline \multirow{4}{*}{ Bus Stop } & 0 & 1 \\
\cline { 2 - 3 } & 1 & 2.78 \\
\cline { 2 - 3 } & 2 & 2.78 \\
\cline { 2 - 3 } & $>2$ & 4.15 \\
\hline \multirow{2}{*}{ School } & 0 & 1 \\
\cline { 2 - 3 } & $>1$ & 1.35 \\
\hline \multirow{2}{*}{$\begin{array}{c}\text { Alcohol Sales } \\
\text { Establishment }\end{array}$} & 0 & 1 \\
\cline { 2 - 3 } & 1 to 8 & 1.12 \\
\cline { 2 - 3 } & $>8$ & 1.56 \\
\hline
\end{tabular}

\subsubsection{Goodness of Fit}

For assessing the goodness of fit, the coefficient of variance (CV) of the calibration factor and cumulative residual (CURE) plots will be utilized. The CURE plots help to determine bias of fit and to identify potential concerns such as long trends in the data, percent of the data exceeding the confidence limits, and vertical changes which could signify the presence of outliers (Lyon et al. 2016). Equations 6 and 7 show the calculation for CV and the variance of the calibration factor $\mathrm{C}$, 
respectively. Further instructions on how to develop the CURE plots can be found in The Calibrator (Lyon et al. 2016) and The Art of Regression Modeling in Road Safety (Hauer 2015).

$$
\begin{gathered}
\mathrm{CV}=\frac{\sqrt{V(C)}}{C} \\
\mathrm{~V}(\mathrm{C})=\frac{\sum_{\text {all sites }}\left(y_{i}+k * y_{i}{ }^{2}\right)}{\left(\sum \text { all sites } \hat{y}_{i}\right)^{2}}
\end{gathered}
$$

Where,

$\mathrm{CV}=$ coeffiecient of variation; $\mathrm{V}(\mathrm{C})=$ variance of calibration factor; $\mathrm{C}=$ estimate of calibration factor; $\mathrm{y}_{\mathrm{i}}=$ observed counts; $\hat{y}_{i}=$ uncalibrated predicted values from SPF; and $\mathrm{k}=$ dispersion parameter (calibrated).

In User's Guide to Develop Highway Safety Manual Safety Performance Function Calibration Factors (Bahar 2014) and the Calibrator (Lyon et al. 2016) it is recommended that the calibrated SPF is acceptable if either:

- Five percent or less of CURE plot ordinates for fitted values (after applying the calibration factor) exceed the $2 \sigma$ limits, or

- $\quad$ The CV of the calibration factor is less than 0.15 .

\subsubsection{Site Selection}

The sites selected for calibration were taken from the cities of Bloomington-Normal, Peoria, Springfield, and Champaign-Urbana. In 2014, IDOT calibrated the HSM SPFs with statewide data from 2006 to 2011 and found that the city of Chicago has significantly different trends of crashes and thus different calibration factor values than for the rest of the state (AASHTO 2014), so intersections located in Chicago were avoided. Instead, the intersections were selected from the aforementioned cities which all have similar populations. As recommended by the HSM, the sites were selected randomly without intentionally considering their crash frequencies. Because the purpose of this study was to predict the crash frequency of the project intersections located in Champaign IL, data from these four communities were used instead of utilizing statewide data. The selection of intersections was mainly focused on those with relatively similar characteristics. For instance, the four-legged intersections were chosen from sites which had a major road AADT within 15000 vehicles per day from the project's main corridor, and intersections located on main corridors within each city were also selected to best represent the project site. On the other hand, because of three-legged signalized intersections were not as common as four-legged signalized intersections, the selection criteria were less strict due to the low number found in these cities. The total four-leg intersections utilized in the calibration were 168, while the total number of 3-legged signalized intersections were 31. 


\subsection{BEFORE AND AFTER STUDY AND EMPIRICAL BAYES METHOD}

The HSM provides computational directions for applying the EB method for performing a before and after analysis. The EB method combines the observed crashes with predicted crashes to eliminate the regression to the mean bias (AASHTO 2010). The specific computational steps are summarized next.

The goal of the EB method is to calculate the number of expected crashes, $\mathrm{N}_{\text {expected, }}$ by combining both the results from the SPF and the data observed on the field with Equation 8.

$$
\mathrm{N}_{\text {expected, } \mathrm{B}}=w_{i, B} * N_{\text {predicted }}+\left(1-w_{i, \mathrm{~B}}\right) * N_{\text {observed }}
$$

Where, $\mathrm{N}_{\text {expected, } \mathrm{B}}$ is the expected number of crashes for the before period and $\mathrm{w}_{\mathrm{i}, \mathrm{B}}$ is computed with Equation 9 as:

$$
\mathrm{W}_{\mathrm{i}, \mathrm{B}}=\frac{1}{1+k * \sum \text { before year } N_{\text {predicted }}}
$$

Where, $\mathrm{N}_{\text {predicted }}$ is calculated from Equation 2 for a given site $\mathrm{i}$, and $\mathrm{k}$ is the Overdispersion parameter of the SPF.

Then, the expected number of crashes in the after period, $N_{\text {expected,A }}$ is estimated with Equation 11. $\mathrm{N}_{\text {expected,A }}$ represents the average number of crashes expected for a similar facility if no treatment was applied to the intersection(s). This is then compared to the number of observed crashes in the after period to calculate the Odds Ratio (OR) for site $i$ as shown in Equation 12. Then, all sites are combined to generate a CMF with Equation 13 below, and the standard deviation for the CMF is given by Equation 14.

$$
\begin{aligned}
& \mathrm{r}_{\mathrm{i}}=\frac{\sum_{\text {after year }} N_{\text {predicted }, A}}{\sum_{\text {before year }} N_{\text {predicted }, B}} \\
& \mathrm{~N}_{\text {expected,A }}=\mathrm{N}_{\text {expected, } \mathrm{B}} * \mathrm{r}_{\mathrm{i}} \\
& O R_{i}=\frac{N_{\text {observed }, A}}{N_{\text {expected }, A}} \\
& \mathrm{CM} F=\frac{\sum_{\text {all sites }} N_{\text {observed }, A} / \sum_{\text {all sites }} N_{\text {expected }, A}}{1+\sum_{\text {all sites }}\left[\left(r_{i}\right)^{2} * N_{\text {expected }, B} *\left(1-w_{i, B}\right)\right] /\left(\sum_{\text {all sites }} N_{\text {expected }, A}\right)^{2}}
\end{aligned}
$$

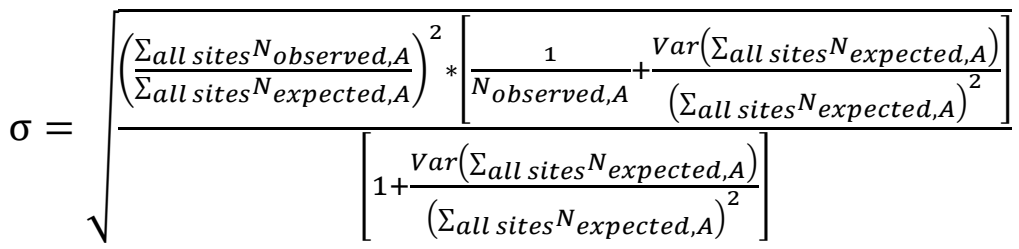

$$
\begin{aligned}
& \operatorname{Var}\left(\sum_{\text {all sites }} N_{\text {expected }, A}\right)=\sum_{\text {all sites }}{r_{i}}^{2} * N_{\text {expected }} *\left(1-w_{i}\right)
\end{aligned}
$$


The HSM also has the following set of guidelines for testing the statistical significance of the CMF relative to the ratio of $\sigma$ to the CMF computed.

- If the absolute value of the ratio $<1.7$, then the conclusion is that the treatment effect is not significant at approximately 90 percent confidence level.

- If the absolute value of the ratio $\geq 1.7$, then the conclusion is that the treatment effect is significant at approximately 90 percent confidence level.

- If the absolute value of the ratio $\geq 2.0$, the conclusion is that the treatment effect is significant at approximately 95 percent confidence level.

\subsection{Shift in Proportions}

As advised by the HSM (AASHTO 2010), in order to gain more insights on the implementation of ASCT technology on this project, a wilcoxon signed rank test was performed to determine if there exist an average shift in the proportions of each crash severity and type. For more details in how to perform this statistical test see Hollander and Wolfe (2014). 


\section{CHAPTER 4: DATA COLLECTION}

The calibration of the HSM SPF for urban signalized intersections requires the acquisition of the crash history, traffic volume data, and geometric characteristics of all intersections included in the calibration. Table 6 presents the specific data requirements for the calibration of the HSM three-leg and four-leg urban signalized intersections utilized in this project. The different characteristics are classified as required or desirable according to the first edition of the HSM (AASHTO 2010).

Table 6. Data Requirements for SPF Calibration

\begin{tabular}{|c|c|c|}
\hline & Required & Desirable \\
\hline Observed Crashes & $\mathrm{x}$ & \\
\hline AADT of major road & $\mathrm{x}$ & \\
\hline AADT of minor road & $\mathrm{x}$ & \\
\hline Number of approaches with right-turn lanes & $\mathrm{x}$ & \\
\hline Number of approaches with left-turn lanes & $\mathrm{x}$ & \\
\hline Type of left turn signal phasing & $\mathrm{x}$ & \\
\hline Intersections where RTOR is prohibited & $\mathrm{x}$ & \\
\hline Presence of lighting & $\mathrm{x}$ & \\
\hline Presence of red-light cameras & $\mathrm{x}$ & \\
\hline Maximum number of lanes cross by pedestrian & $\mathrm{x}$ & \\
\hline Pedestrian daily volumes & $\mathrm{x}$ & \\
\hline Number of schools within 1000 ft & & $\mathrm{x}$ \\
\hline Number of alcohol sale establishments within $1000 \mathrm{ft}$ & & $\mathrm{x}$ \\
\hline Number of bus stops within 1000ft & & $\mathrm{x}$ \\
\hline
\end{tabular}

The study period for this project was selected to be 2012-2016 which includes the before and after periods to be utilized when applying the EB method. The ASCT was installed in April of 2015 until December of 2016. Crash data for 2012-2014 was used for the "before" conditions, and the data for May 2015-Oct 2016 was used for the "after" conditions. The crash history for the analysis period was obtained from IDOT. The crash data was provided in the form of spreadsheets which included the geographical coordinates of each crash. IDOT also provided the shapefiles for Illinois Counties found on the IDOT website (Illinois Technology Transfer Center). The crash coordinates were combined with these shapefiles to assign crashes to each intersection. Crashes within $250 \mathrm{ft}$ from an intersection were considered intersection-related crashes in accordance to the definition provided in HSM (AASHTO 2010). The ArcGIS files and crash history included useful specific information about crashes and intersection characteristics including but not limited to geographic coordinates, crash severity, collision type, number of vehicles involved in the crash, AADT, AADT year, speed limits, and number of lanes per intersection approach. When AADTs were not available for a particular year, the following guidelines provided by HSM (2010) were applied:

- If data are available for only a single year, that same value is assumed to apply to other years of calibration. 
- If two or more years of AADT are available, the AADT for intervening years are computed by interpolation.

In the cases where AADT for either a major or minor road was not available in any of the years in the calibration period, the most recent AADT value in the system was assumed for all years of calibration. This only happened on 4 intersections; for the rest, at least one year of AADT within the calibration period was available.

Another requirement as shown in Table 6 was the number of approaches with right-turn lanes and left-turn lanes. Although the shapefiles included the number of lanes per road, it was unclear whether a certain intersection approach had a left-turn lane or right-turn lane. Therefore, District 4 (Peoria) and District 6 (Springfield) provided the lane type data for all requested intersections. These Districts also provided other intersection characteristics for the cities of Peoria and Springfield such as the type of left-turn signal phasing, the presence of right-turn-on-red-prohibited signs, and the presence of intersection lighting. On the other hand, for Bloomington-Normal and Champaign-Urbana urbanized areas, aerial photographs and Google Maps street views were utilized for obtaining the intersection and lane characteristics. The type of left-turn signal phasing (i.e protected only, permissive only, or both) was determined according to the number of signal heads per approach. Figure 1 below presents an example of the most common cases encountered in the data collection.

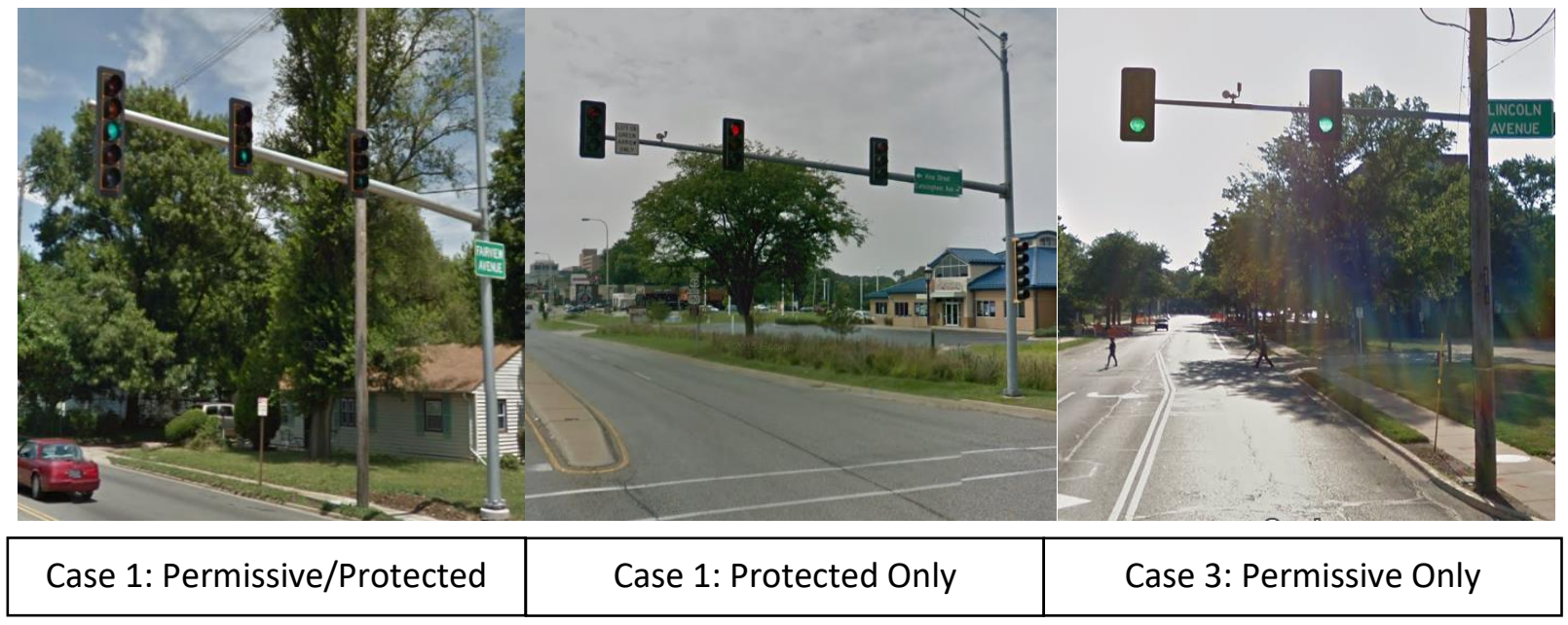

Figure 1. Cases for determining type of left-turn signal phasing.

For the pedestrian SPF calibration, as shown in Table 6, extra data characteristics are required such as pedestrian daily volumes, presence of schools, presence of alcohol sales establishments, and presence of bus stops within $1000 \mathrm{ft}$ from intersections. For this, an online tool was implemented which loads Google Maps data in the background and places a circle of specific radius in any desired location on top of it (Beattie, 2018). Each intersection was individually searched and manually counted as shown in Figure 2 and Figure 3. Google Maps labels the bus stops, schools, and businesses with specific symbols and each business was further researched to determine whether they fell on the alcohol sales establishment category or not. 


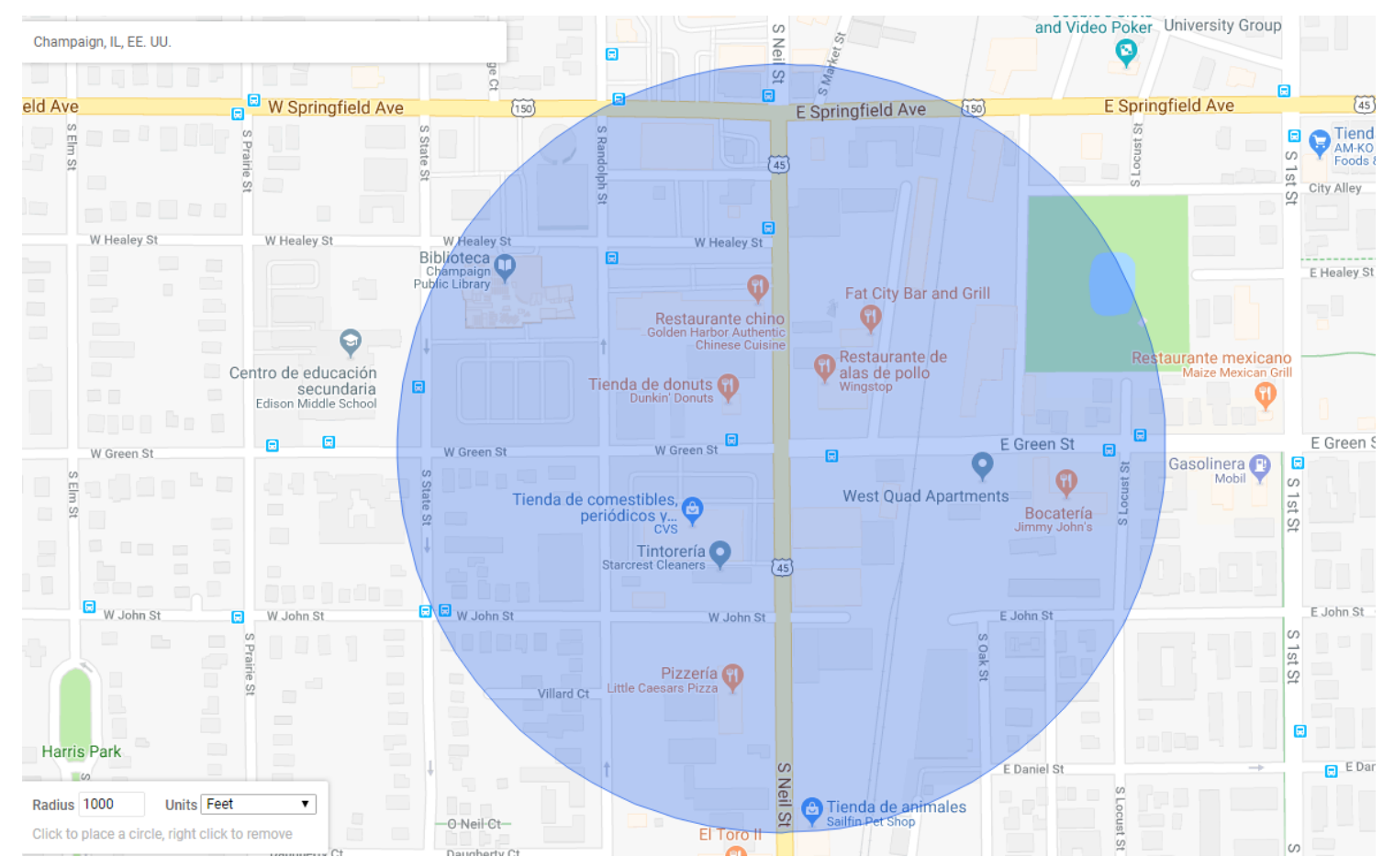

Figure 2. 1000-ft radius circle Placed with github app on top of Google Maps.

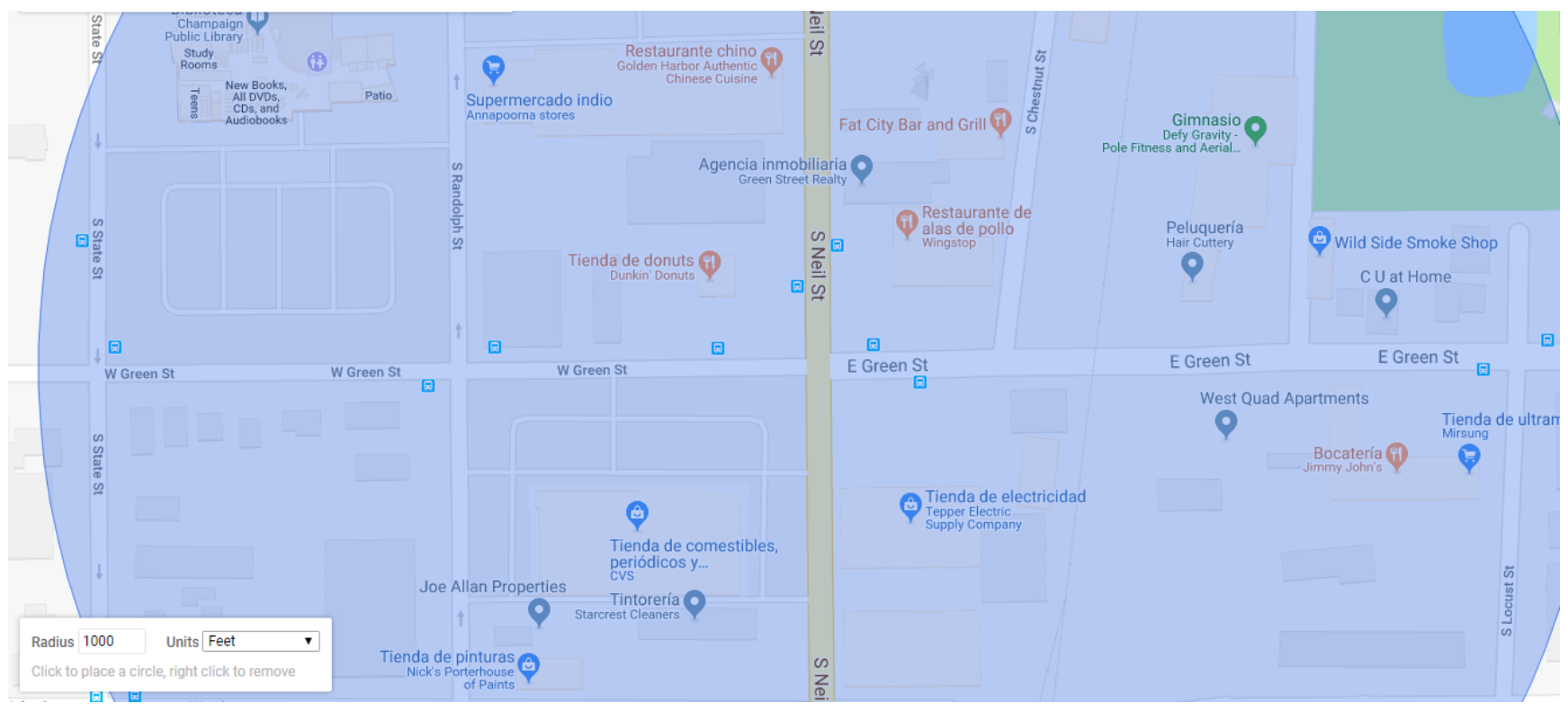

Figure 3. Zoomed in 1000-ft radius circle utilized to locate schools, businesses and bus stops near intersections.

Lastly, daily pedestrian volume counts were required for the calibration process. Other states which have performed statewide calibrations (Xie et al. 2011; Srinivasan et al. 2011; Shin et al. 2014; Sun et 
al. 2014) indicated the challenges in obtaining pedestrian volumes for calibrating the HSM models. These states compensated for the lack of pedestrian data by assuming a Medium level of pedestrian activity from the Estimates of Pedestrian Crossing Volumes Based on General Level of Pedestrian Activity table that is provided by HSM for three-leg and four-leg urban signalized intersections (AASHTO 2010). In this project the research team faced the same challenge regarding the lack of pedestrian data and followed the approach previously taken. So, a medium level of pedestrian volumes was assumed in this project due to the limited availability of pedestrian count data, but the research team verified that the assumption is valid as discussed below.

To estimate the amount pedestrian activity (e.g. low, medium-low, medium, etc.), a limited sample of pedestrian counts was utilized from the Champaign-Urbana Urbanized Area Transportation Study (CUUATS). These pedestrian counts included mostly 2012 morning, noon, and afternoon peak-hour pedestrian counts for 33 intersections in Champaign IL. These 33 intersections were intersections which were a part of the calibration process. Therefore, since the calibration was performed with intersections with similar AADT and geometric characteristic from four cities, the research team assumed that these 33 intersections represented the average amount of pedestrian activity for all intersections in the study. These volumes were utilized to estimate the 24-hour volumes for each intersection by multiplying the sum of the peak hour volumes per intersection by a multiplier. The multiplier of $1 / 0.28$ was obtained by computing the ratio of 3 -hour volume (am, noon, and pm peak hours) to 24-hour volume of the pedestrian counts obtained in (Hocherman et al. 1988). The resulting average was 727 pedestrians/day which was very close to the medium level of pedestrian activity (i.e. 700 pedestrian/day) given by AASHTO. 


\section{CHAPTER 5: CASE STUDY}

The project consists of six intersections along Neil St. located in the city of Champaign, IL. The six intersections were operating as a time-based coordinated system before the ASCT system was installed. Out of the six intersections, five are four-legged intersections and one is three-legged intersection. Figure 4 presents an aerial image of where the intersections are located relative to the Champaign-Urbana urbanized area, and Figure 5 shows a zoomed in aerial view the six intersections.

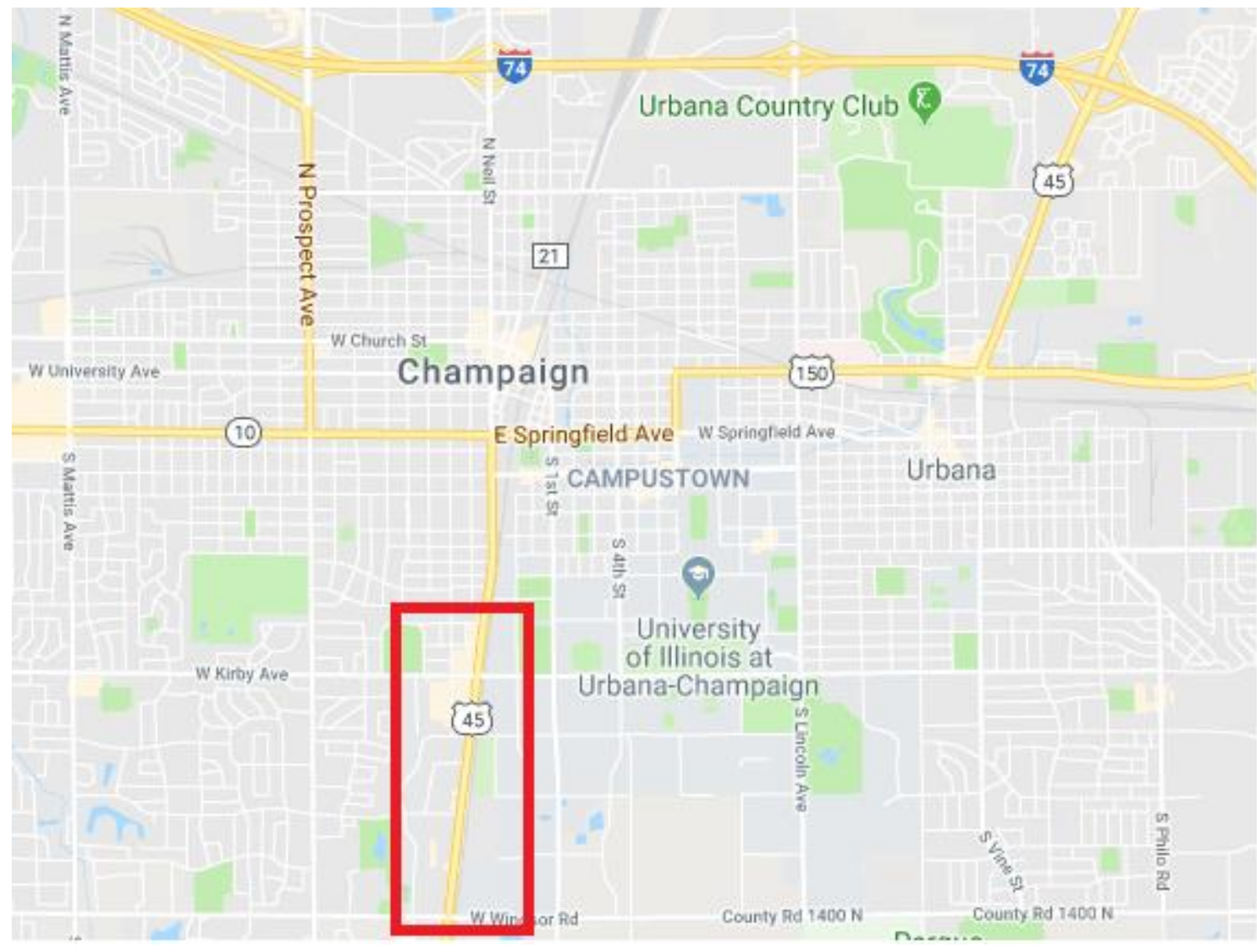

Figure 4. Aerial view of project site. 


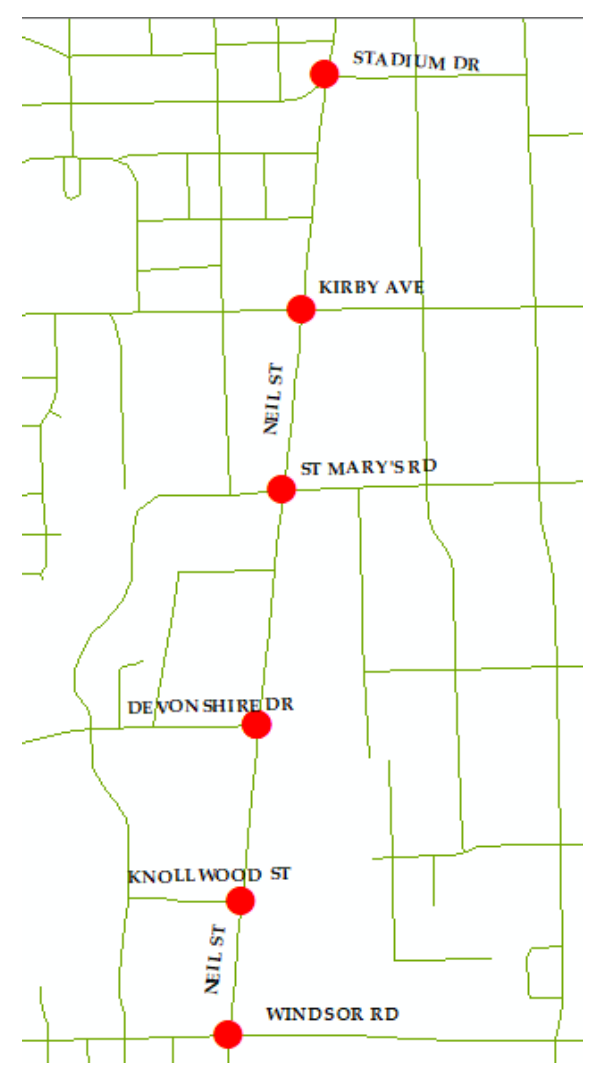

Figure 5. Zoomed-in aerial view of project intersections.

The following Tables present the breakdown of crashes and average AADT for the years in the before and after periods. Table 7 shows the averages taken from the years 2012 to 2016. It is worth mentioning that the project intersections had no pedestrian crashes and only one bicycle crash (2012) in the entire study period. Knollwood St. AADT was not available on the shape files and was estimated with manual counts from video recordings available to the research team. Tables 8 through 10 present the breakdown of crashes per intersection by severity. For a more comprehensive breakdown of crashes in the entire corridor including intersection and segment crashes along the entire corridor, Appendix D presents the breakdown of crashes by severity and type.

Table 7. Average AADT of Project Intersections

\begin{tabular}{|c|c|c|c|}
\hline $\begin{array}{c}\text { Major } \\
\text { Road }\end{array}$ & $\begin{array}{c}\text { Minor } \\
\text { Road }\end{array}$ & $\begin{array}{c}\text { AADT } \\
\text { Major Road }\end{array}$ & $\begin{array}{c}\text { AADT } \\
\text { Minor Road }\end{array}$ \\
\hline Neil St. & Stadium Dr. & 21370 & 3380 \\
\hline Neil St. & Kirby Ave. & 21240 & 15560 \\
\hline Neil St. & St. Mary's Rd. & 19600 & 4240 \\
\hline Neil St. & Devonshire Dr. & 19770 & 3240 \\
\hline Neil St. & Knollwood St. & 19200 & 1300 \\
\hline Neil St. & Windsor Rd. & 19200 & 13850 \\
\hline
\end{tabular}


Table 8. Total Crashes per Year

\begin{tabular}{|c|c|c|c|c|c|c|c|}
\hline \multicolumn{2}{|c|}{} & \multicolumn{3}{|c|}{ Before (36 months) } & \multicolumn{2}{|c|}{ After (18 months) } & \\
\hline Major road & Minor Road & $\mathbf{2 0 1 2}$ & $\mathbf{2 0 1 3}$ & $\mathbf{2 0 1 4}$ & $\begin{array}{c}\text { May2015- } \\
\text { Dec2016 }\end{array}$ & $\begin{array}{c}\text { Jan2016- } \\
\text { Oct2016 }\end{array}$ & Total \\
\hline Neil St. & Stadium Dr. & 6 & 3 & 7 & 3 & 2 & 21 \\
\hline Neil St. & Kirby Ave. & 22 & 17 & 15 & 13 & 14 & 81 \\
\hline Neil St. & St. Mary's Rd. & 3 & 4 & 4 & 6 & 6 & 23 \\
\hline Neil St. & Devonshire Dr. & 5 & 3 & 4 & 5 & 2 & 19 \\
\hline Neil St. & Knollwood St. & 3 & 0 & 5 & 3 & 1 & 12 \\
\hline Neil St. & Windsor Rd. & 9 & 15 & 9 & 6 & 7 & 46 \\
\hline & Sum & 48 & 42 & 44 & 36 & 32 & 202 \\
\hline
\end{tabular}

Table 9. Fatal and Injury Crashes per Year

\begin{tabular}{|c|c|c|c|c|c|c|c|}
\hline \multicolumn{2}{|c|}{} & \multicolumn{3}{|c|}{ Before (36 months) } & \multicolumn{2}{|c|}{ After (18 months) } & \\
\hline Major road & Minor Road & $\mathbf{2 0 1 2}$ & $\mathbf{2 0 1 3}$ & $\mathbf{2 0 1 4}$ & $\begin{array}{c}\text { May2015- } \\
\text { Dec2016 }\end{array}$ & $\begin{array}{c}\text { Jan2016- } \\
\text { Oct2016 }\end{array}$ & Total \\
\hline Neil St. & Stadium Dr. & 1 & 2 & 1 & 0 & 0 & 4 \\
\hline Neil St. & Kirby Ave. & 6 & 4 & 6 & 2 & 1 & 19 \\
\hline Neil St. & St. Mary's Rd. & 1 & 1 & 2 & 4 & 0 & 8 \\
\hline Neil St. & Devonshire Dr. & 1 & 1 & 0 & 1 & 0 & 3 \\
\hline Neil St. & Knollwood St. & 0 & 0 & 2 & 0 & 1 & 3 \\
\hline Neil St. & Windsor Rd. & 4 & 0 & 5 & 1 & 2 & 12 \\
\hline & Sum & 13 & 8 & 16 & 8 & 4 & 49 \\
\hline
\end{tabular}

Table 10. PDO Crashes per Year

\begin{tabular}{|c|c|c|c|c|c|c|c|}
\hline \multicolumn{2}{|c|}{} & \multicolumn{3}{|c|}{ Before (36 months) } & \multicolumn{2}{|c|}{ After (18 months) } & \\
\hline Major road & Minor Road & $\mathbf{2 0 1 2}$ & $\mathbf{2 0 1 3}$ & $\mathbf{2 0 1 4}$ & $\begin{array}{c}\text { May2015- } \\
\text { Dec2016 }\end{array}$ & $\begin{array}{c}\text { Jan2016- } \\
\text { Oct2016 }\end{array}$ & Total \\
\hline Neil St. & Stadium Dr. & 5 & 1 & 6 & 3 & 2 & 17 \\
\hline Neil St. & Kirby Ave. & 16 & 13 & 9 & 11 & 13 & 62 \\
\hline Neil St. & St. Mary's Rd. & 2 & 3 & 2 & 2 & 6 & 15 \\
\hline Neil St. & Devonshire Dr. & 4 & 2 & 4 & 4 & 2 & 16 \\
\hline Neil St. & Knollwood St. & 3 & 0 & 3 & 3 & 0 & 9 \\
\hline Neil St. & Windsor Rd. & 5 & 15 & 4 & 5 & 5 & 34 \\
\hline & Sum & 35 & 34 & 28 & 28 & 28 & 153 \\
\hline
\end{tabular}


Table 8 through Table 10 show that there is a potential for a crash reduction in FI crashes, while there is potential for a crash increase for total and PDO crashes. This can be observed by naively comparing the average crash per year in the before period to the after period. For total crashes, the average in the before period was equal to 67 crashes/18 months and the number of observed crashes in the after period was 68. Similarly, the average crash frequency in the before period for PDO crashes was 48.5 crashes $/ 18$ months and the number of observed crashes in the after period was 56 . On the other hand, for Fl crashes, the average in the before period was equal to 18.5 crashes/18 months, while the observed number of crashes in the after period was equal to 12 . To test these claims statistically, the following sections show the results of the calibration and the EB before and after study.

\subsection{CALIBRATION RESULTS}

The calibration was performed with 168 four-leg intersections and 31 three-leg intersections. As mentioned in the methodology section, some SPF required more than one calibration factors and those were determined with their respective coefficient of variance. Table 11 below presents the number of crashes utilized for calibration across all 199 intersections divided by their respective crash type and severity. Then, Table 12 presents the four-leg calibration results and Table 13 presents the three-leg calibration results.

Table 11. Crashes Utilized for SPF Calibration Over 5 Years

\begin{tabular}{|c|c|c|c|c|c|}
\hline Number of legs & Crash Type & $\begin{array}{c}\text { Crash } \\
\text { Severity }\end{array}$ & $\begin{array}{c}\text { Number of } \\
\text { Crashes }\end{array}$ & Avg/Intersection/year & $\begin{array}{l}\text { Std } \\
\text { Dev. }\end{array}$ \\
\hline \multirow{7}{*}{$\begin{array}{l}\text { Four-legged } \\
\text { intersections }\end{array}$} & \multirow{3}{*}{ Multiple Vehicle } & Total & 7819 & 9.3 & 7.2 \\
\hline & & $\mathrm{FI}$ & 1876 & 2.23 & 5.74 \\
\hline & & PDO & 5943 & 7.1 & 5.7 \\
\hline & Pedestrian & - & 112 & 0.13 & 0.38 \\
\hline & \multirow{3}{*}{ Single Vehicle } & Total & 581 & 0.72 & 0.86 \\
\hline & & $\mathrm{FI}$ & 277 & 0.37 & 0.62 \\
\hline & & PDO & 304 & 0.36 & 0.62 \\
\hline \multirow{7}{*}{$\begin{array}{l}\text { Three-legged } \\
\text { intersections }\end{array}$} & \multirow{3}{*}{ Multiple Vehicle } & Total & 640 & 4.1 & 3.9 \\
\hline & & $\mathrm{FI}$ & 140 & 0.87 & 1.1 \\
\hline & & PDO & 500 & 3.2 & 3.2 \\
\hline & Pedestrian & - & 4 & 0.02 & 0.16 \\
\hline & \multirow{3}{*}{ Single Vehicle } & Total & 65 & 0.42 & 0.68 \\
\hline & & $\mathrm{FI}$ & 25 & 0.16 & 0.4 \\
\hline & & PDO & 40 & 0.26 & 0.56 \\
\hline
\end{tabular}


Table 12. SPF Calibration Results for Four-Leg Intersection Models

\begin{tabular}{|c|c|c|c|c|c|}
\hline Crash Type & $\begin{array}{l}\text { Crash } \\
\text { Severity }\end{array}$ & $\begin{array}{c}\text { Criteria } \\
\left(\text { (AADT }_{\text {minor }}+\text { AADT }_{\text {major }}\right)\end{array}$ & $\begin{array}{l}\text { Calibration } \\
\text { Factor }\end{array}$ & SD & CV \\
\hline \multirow{9}{*}{$\begin{array}{l}\text { Multiple } \\
\text { Vehicle }\end{array}$} & \multirow{3}{*}{ Total } & AADT $\leq 20000$ & 3.39 & 0.305 & 0.090 \\
\hline & & $20000<$ AADT $\leq 30000$ & 2.83 & 0.255 & 0.090 \\
\hline & & AADT $>30000$ & 4.62 & 0.477 & 0.103 \\
\hline & \multirow{3}{*}{$\mathrm{FI}$} & AADT $\leq 20000$ & 2.85 & 0.283 & 0.100 \\
\hline & & $20000<$ AADT $\leq 30000$ & 2.15 & 0.213 & 0.099 \\
\hline & & AADT $>30000$ & 3.42 & 0.339 & 0.099 \\
\hline & \multirow{3}{*}{ PDO } & AADT $\leq 20000$ & 3.82 & 0.360 & 0.094 \\
\hline & & $20000<$ AADT $\leq 30000$ & 3.31 & 0.316 & 0.096 \\
\hline & & AADT $>30000$ & 5.45 & 0.605 & 0.111 \\
\hline Pedestrian & - & - & 0.42 & 0.049 & 0.115 \\
\hline \multirow{4}{*}{$\begin{array}{c}\text { Single } \\
\text { Vehicle }\end{array}$} & Total & - & 3.80 & 0.266 & 0.070 \\
\hline & \multirow{2}{*}{$\mathrm{FI}$} & $A A D T \leq 30000$ & 7.02 & 0.544 & 0.077 \\
\hline & & AADT >30000 & 8.51 & 0.902 & 0.108 \\
\hline & PDO & - & 2.79 & 0.254 & 0.091 \\
\hline
\end{tabular}

For SPFs in which different calibration factors were determined, different criteria were used to identify the different trends of the data. For the multiple-vehicle models it was found that ranges of total AADT (i.e. the sum of AADT of minor and major road) had significantly different trends. For all multiple vehicle models, the total AADT was divided into three ranges: total AADT $\leq 20000,20000<$ total AADT $\leq 30000$, and total AADT $>30000$. If the calibration factor varied by at least 15 percent per range, and the $\mathrm{CV}$ was less than 0.15 , a new calibration factor was determined. This percentage difference was utilized as it was the maximum percentage change found without compromising the accuracy of the calibration factor. As explained in the User's Guide to Develop Highway Safety Manual Safety Performance Function Calibration Factors (Bahar 2014), splitting the data when the calibrations factors vary for less than 10 percent may not be reasonable with the data available for this project, while splitting the data when the calibration factors vary for more than 50 percent could allow too much variability within each factor. Lastly, the only single-vehicle SPF with two calibration factors was the fatal and injury SPF. For this, the AADT total was split only between total AADT $\leq 30000$ and total AADT $>30000$ because the 20000 splits did not show any significant change in the trend of crash frequency.

To determine the AADT ranges to split the calibration factors, the CURE plots trends were examined. Figure 6 shows the total multiple-vehicle crashes for four-legged intersection CURE plot as a function of the total AADT. In this plot, a single calibration factor was applied, and the resulting CURE plot identifies three tends. A trend of slight overprediction when AADT $<20000$, and trend of high overprediction between 20000 and 30000, and an underprediction trend when AADT>30000. Once these trends were identified, the calibration was split, and the resulting CURE plots shown in Figure 7 and Figure 8 were developed as a function of total AADT and number of predicted crashes, 
respectively. These are a sample of how the ranges were determined for the total four-legged intersection model, but the rest of the CURE plots for all SPFs can be found in Appendix A.

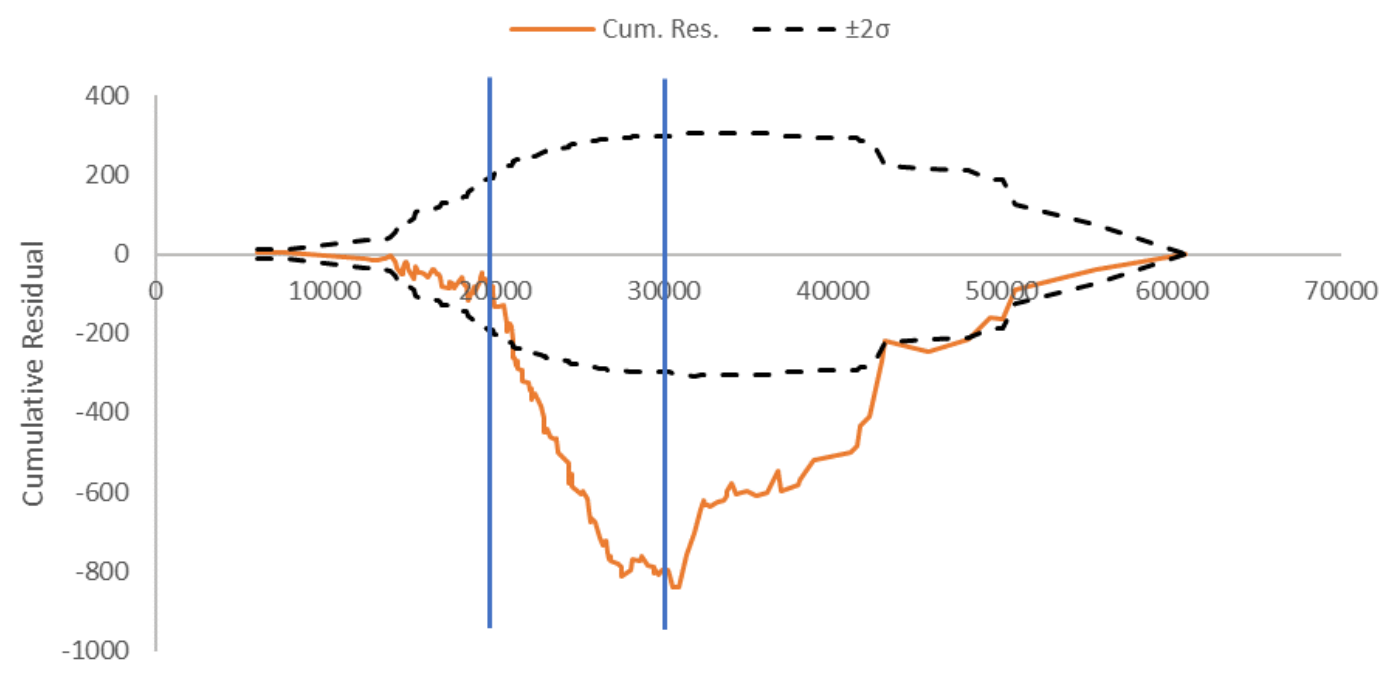

AADT minor + AADT major

Figure 6. CURE plot for total multiple-vehicle crashes for four-legged intersections as a function of total AADT with a single calibration factor.

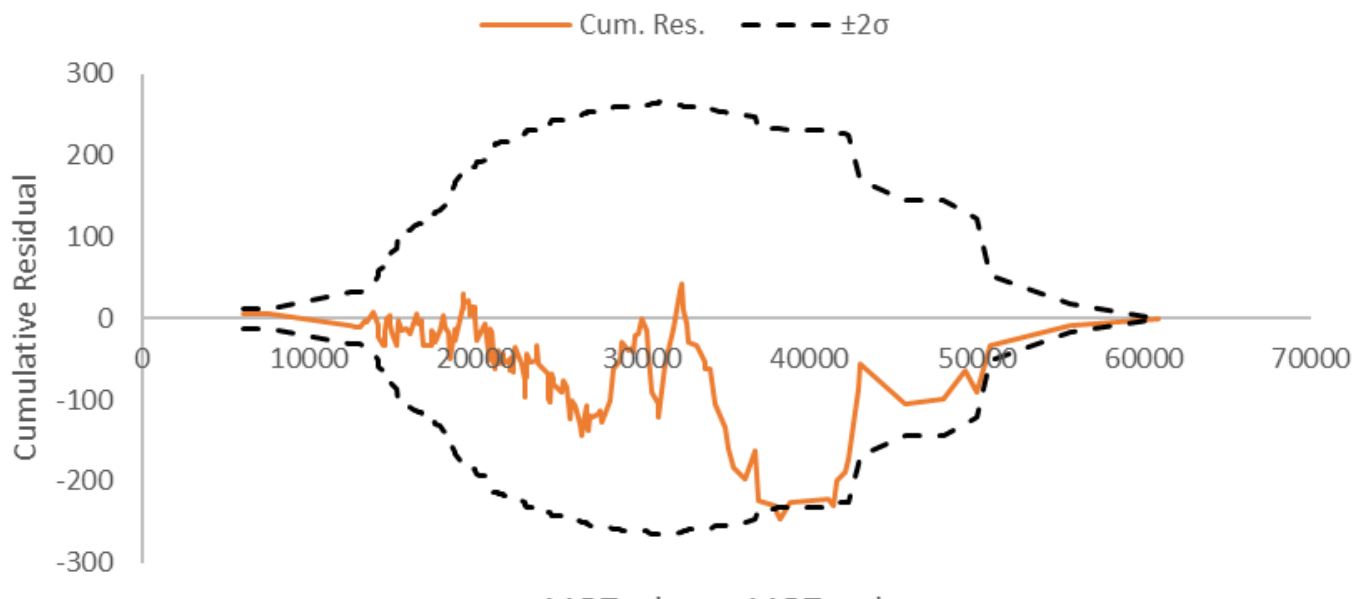

AADT minor + AADT major

Figure 7. CURE plot for total multiple-vehicle crashes for four-legged intersections as a function of total AADT with multiple calibration factors. 


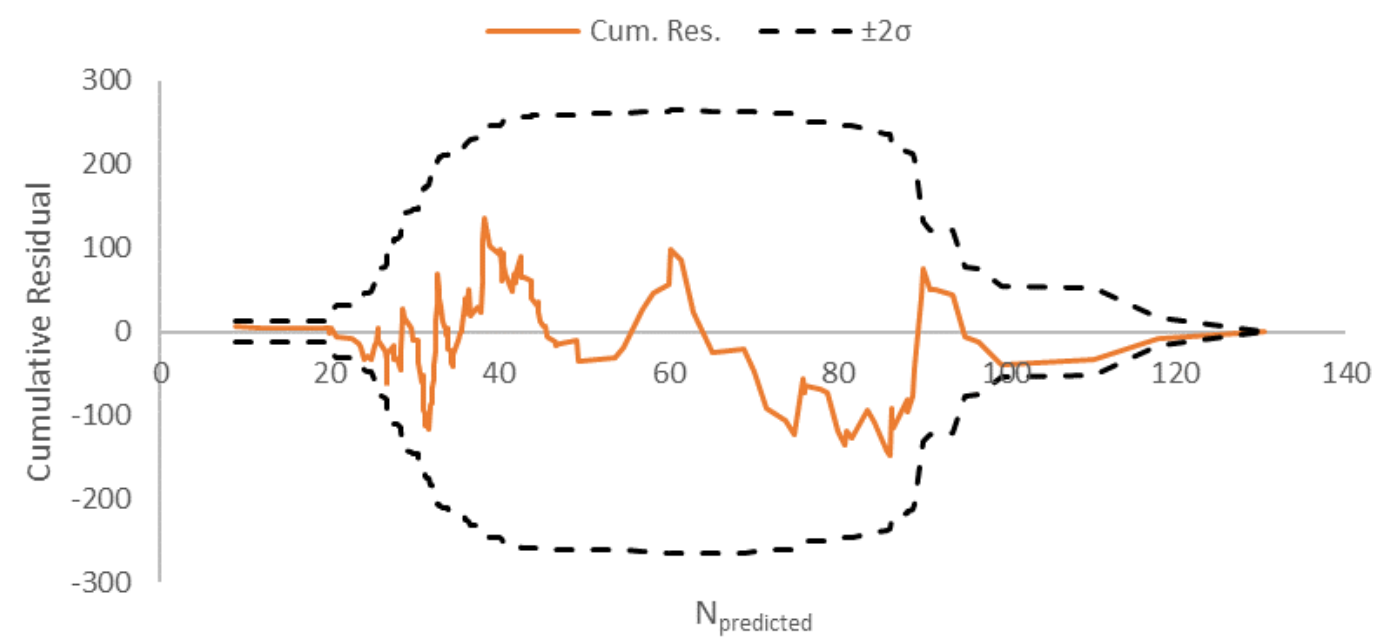

Figure 8. CURE plot for total multiple-vehicle crashes for four-legged intersections as a function of $\mathrm{N}_{\text {predicted }}$ with multiple calibration factors.

Table 13. SPF Calibration Results for Three-Leg Intersection Models

\begin{tabular}{|c|c|c|c|c|}
\hline $\begin{array}{c}\text { Crash } \\
\text { Type }\end{array}$ & $\begin{array}{c}\text { Crash } \\
\text { Severity }\end{array}$ & $\begin{array}{c}\text { Calibration } \\
\text { Factor }\end{array}$ & SD & CV \\
\hline \multirow{2}{*}{$\begin{array}{c}\text { Multiple } \\
\text { Vehicle }\end{array}$} & Total & 2.509 & 0.342 & 0.136 \\
\cline { 2 - 5 } & FI & 1.600 & 0.252 & 0.158 \\
\cline { 2 - 5 } & PDO & 3.130 & 0.452 & 0.144 \\
\hline Pedestrian & - & 0.22 & 0.124 & 0.557 \\
\hline \multirow{2}{*}{$\begin{array}{c}\text { Single } \\
\text { Vehicle }\end{array}$} & Total & 2.688 & 0.498 & 0.185 \\
\cline { 2 - 5 } & FI & 3.474 & 0.820 & 0.236 \\
\cline { 2 - 5 } & PDO & 3.876 & 0.802 & 0.207 \\
\hline
\end{tabular}

As expected, the CV values from the three-leg models are higher than those of the four-leg models. This may be due to the number of three-leg intersections being significantly low compared to those of the four-leg intersections. Although the recommendation of at least 100 crashes per calibration was not met for all the three-leg models, most of the three-leg calibrated models had a CURE plot that fell within the 95 percent confidence interval. Similar to the four-legged intersections case, Figures 9 and 10 show the CURE plots for multiple-vehicle total crashes as a function of total AADT and $\mathrm{N}_{\text {predicted, }}$ and no clear trend trends were identified to make any splits. For this reason, the threeleg models remained with a single calibration factor. All CURE plots for three-leg SPFs can be found in Appendix A. It is worth mentioning that the single-vehicle three-leg models were not utilized in the development of CMFs because those types of crashes were not observed in both the before or after period. 


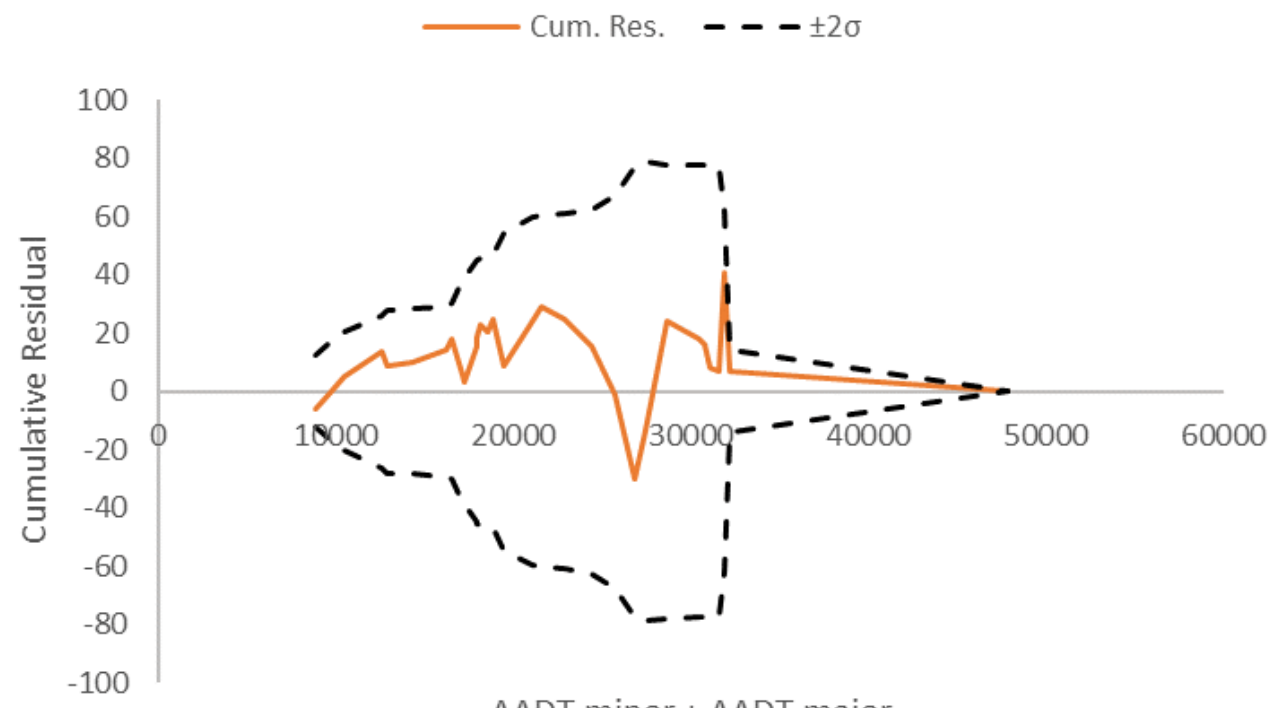

AADT minor + AADT major

Figure 9. CURE plot for total multiple-vehicle crashes for three-legged intersections as a function of total AADT with a single calibration factor.

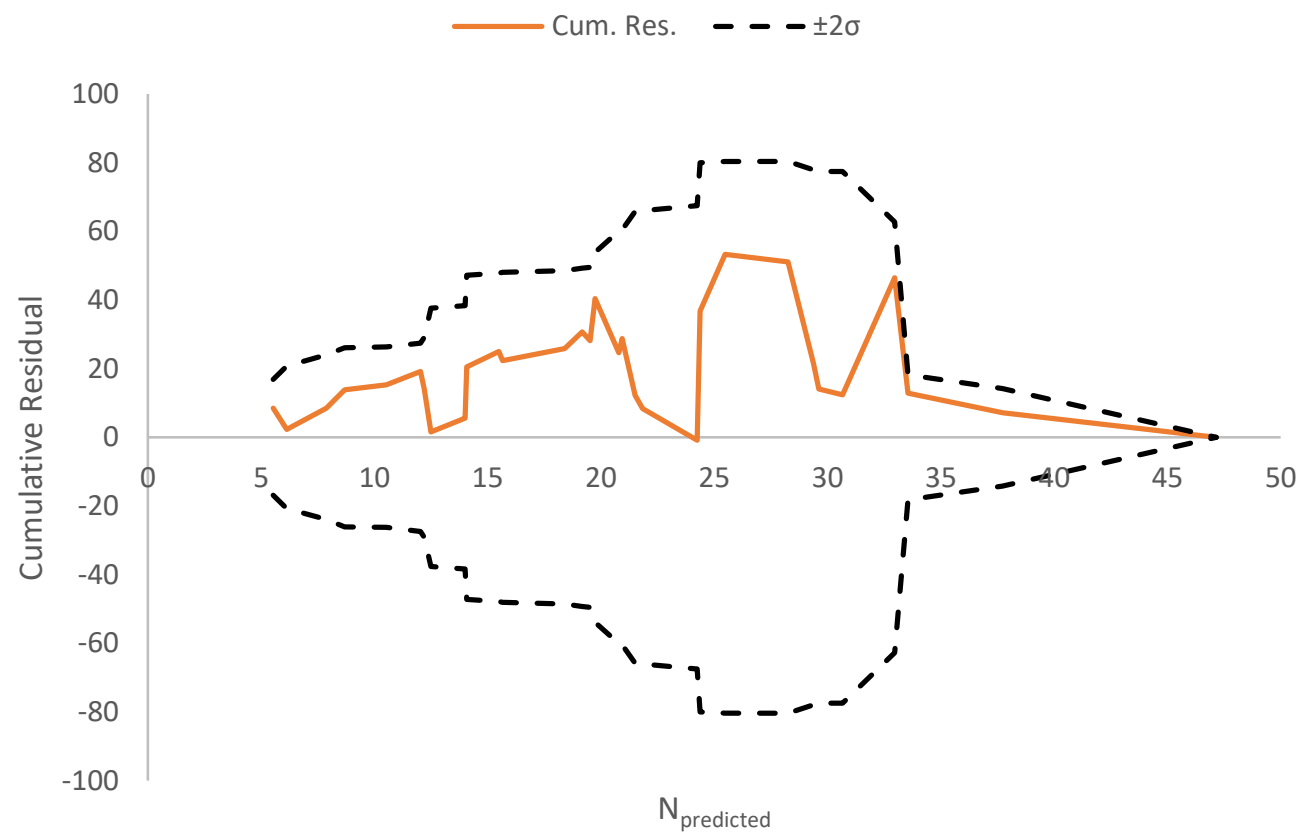

Figure 10. CURE plot for total multiple-vehicle crashes for three-legged intersections as a function of $\mathbf{N}_{\text {predicted }}$ with a single calibration factor.

The Illinois specific SPF developed for Illinois (Tegge et al 2010) were also calibrated for comparison, and the results are shown below in Table 14. For this calibration, all 199 intersections were utilized for each model since they do not distinguish between three and four-legged intersections. It is worth 
emphasizing that the KAB SPF calibration did not include Type $C$ injury crashes to maintain the SPF consistent with the data from which it was originally developed.

Table 14. Illinois SPF Calibration Results for Urban Intersection Models

\begin{tabular}{|c|c|c|c|c|}
\hline Crash Severity & Calibration Factor & $\begin{array}{c}\text { Criteria } \\
\left(A A D T_{\text {minor }}+A A D T_{\text {major }}\right)\end{array}$ & SD & CV \\
\hline \multirow{3}{*}{$\mathrm{KAB}$} & 1.48 & AADT $\leq 20000$ & 0.187 & 0.127 \\
\hline & 1.14 & $20000<$ AADT $\leq 30000$ & 0.141 & 0.124 \\
\hline & 1.46 & AADT $>30000$ & 0.198 & 0.135 \\
\hline \multirow{2}{*}{ Type A Injury } & 1.55 & AADT $\leq 20000$ & 0.258 & 0.167 \\
\hline & 1.12 & AADT>20000 & 0.138 & 0.123 \\
\hline \multirow{3}{*}{ Type B Injury } & 1.27 & AADT $<20000$ & 0.173 & 0.159 \\
\hline & 0.952 & $20000<A A D T \leq 30000$ & 0.118 & 0.122 \\
\hline & 1.10 & AADT $>30000$ & 0.155 & 0.141 \\
\hline
\end{tabular}

The calibration factors were split with the same criteria in which the total AADT was separated with the 20000 and 30000 marks. For the type A injury SPF, the 30000 split was not significant, so it was only separated with AADT $\leq 20000$ and AADT $>20000$. Figure 11 shows the different trends found as a function of total AADT and $\mathrm{N}_{\text {predicted. }}$. Although the exact number of the trend is slightly less than 30000 , the research team decided to keep it as 30000 for consistency with the other calibrations, and because it is still a reasonable approximation. It is worth noting that all Illinois CURE plots fall within the 95 percent confidence interval (see Appendix A), but the CV are consistently higher than the multiple-vehicle models and comparable to the single-vehicle models from the HSM. Figures 12 and 13 show the CURE plot after multiple calibration factors were applied. 


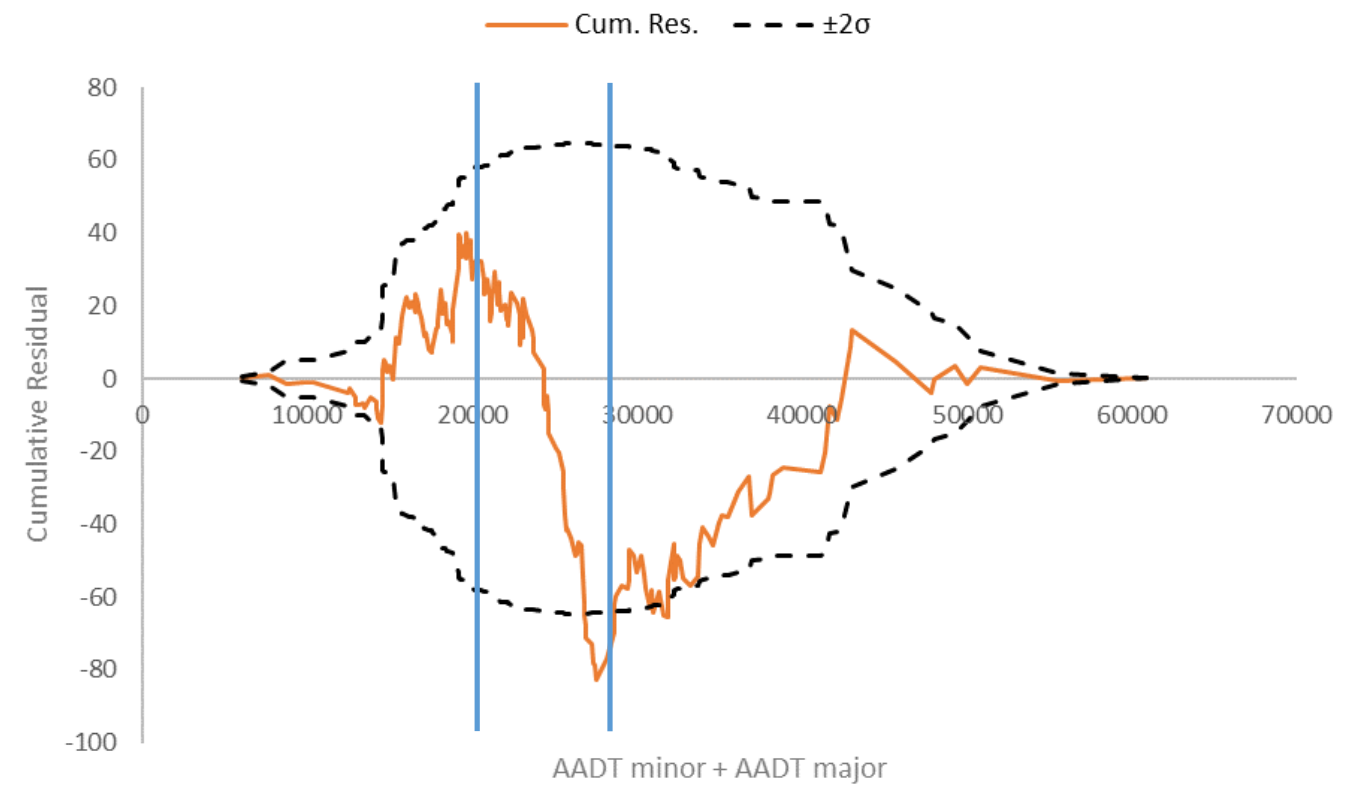

Figure 11. CURE plot for fatal and injury crashes (KAB) in urban signalized intersections as a function of total AADT with a single calibration factor.

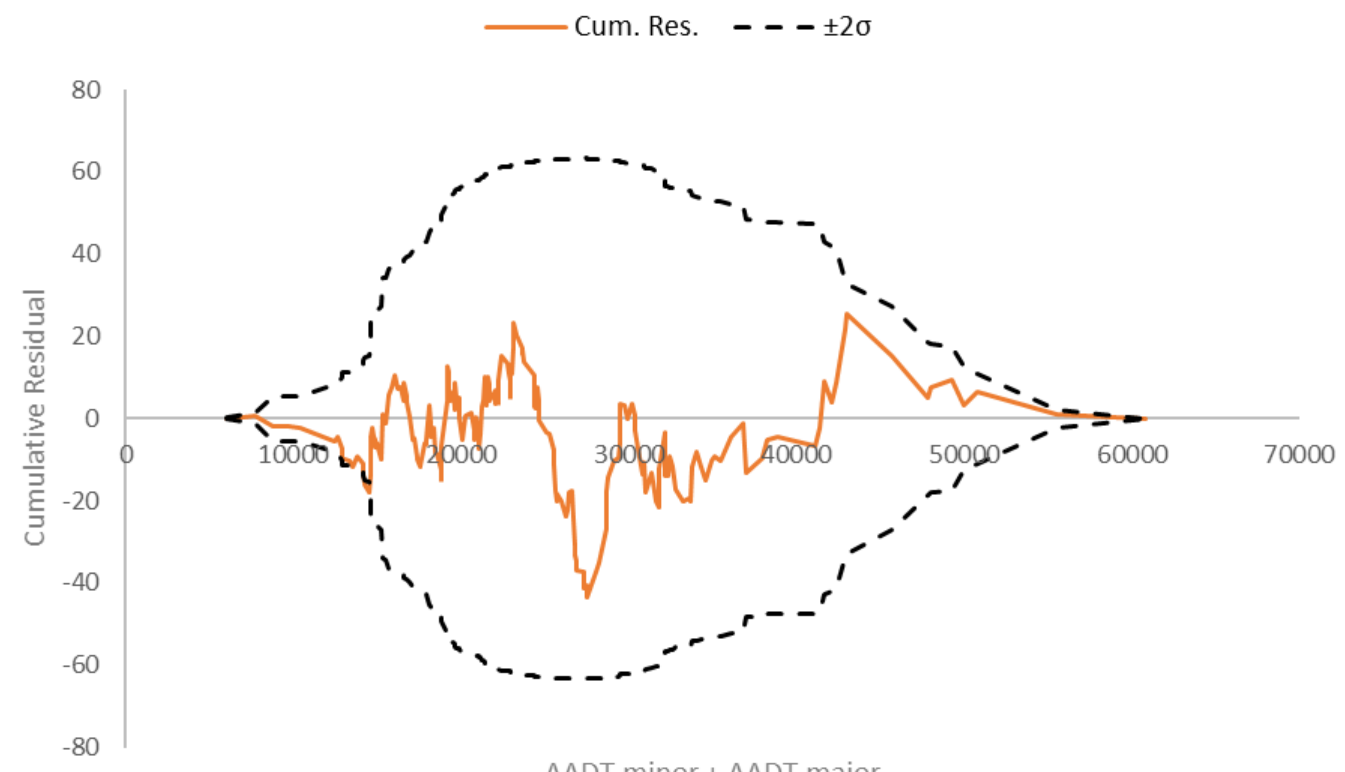

AADT minor + AADT major

Figure 12. CURE plot for fatal and injury crashes (KAB) in urban signalized intersections as a function of total AADT with multiple calibration factors. 

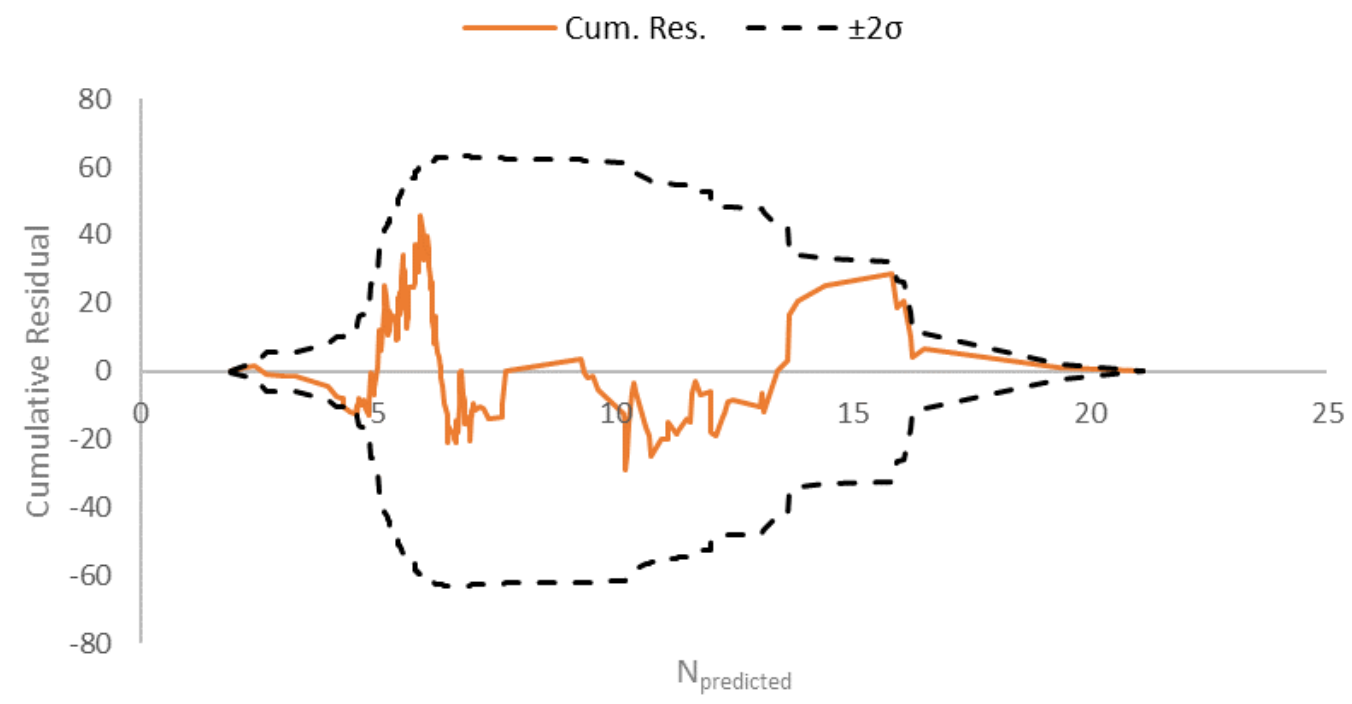

Figure 13. CURE plot for fatal and injury crashes (KAB) in urban signalized intersections as a function of $\mathrm{N}_{\text {predicted }}$ with multiple calibration factors.

Additionally, as mentioned before, the Illinois SPFs only account for the injury crashes and do not estimate the total and PDO crashes. For these reasons, they will only be used for comparison to check whether the same trends are captured by both models. There is not a direct equivalence among models since the HSM are split between three and four-legged intersections and further split into single and multiple-vehicle crashes, and pedestrian and bike crashes. Nonetheless, even when the KAB SPF excludes the type $C$ crashes, similar trends should be captured by both the KAB and the $\mathrm{FI}$ models.

Finally, the bike factor was calibrated to local conditions and the resulting $f_{\text {bike }}$ is 0.011 . This factor was calculated with the bike crashes from all 199 intersections.

\subsection{EB BEFORE AND AFTER RESULTS}

After all calibrations were performed, the CMF and standard error were computed with Equations 13 and 14 , respectively. The results were divided into four sections. The first one considering only fourlegged intersections, the second one considering three-legged intersections, the third one combines both three and four-legged intersections to produce a CMF for the entire project, and the last section are CMFs developed with the Illinois specific models for comparison purposes.

\subsubsection{Four-Legged Intersections}

Attempts were made to develop CMF for the multiple and single-vehicle SPF from the chapter 12 in the HSM (AASHTO 2010). However, due to the low crash frequency of single-vehicle crashes, a singlevehicle crash CMF alone was not computed. The results are presented in Table 15, and no statistically significant CMF were found at 95 percent confidence level. 
Table 15. Four-Legged Signalized Intersection CMF Results and Standard Error

\begin{tabular}{|c|c|c|}
\hline Crash Severity & CMF & SE \\
\hline Total & 1.00 & 0.16 \\
\hline FI & 0.67 & 0.23 \\
\hline PDO & 1.09 & 0.20 \\
\hline
\end{tabular}

For multiple vehicle FI crashes, the CMF was 0.67, which was not statistically significant at 95 percent confidence level (it was significant at 87 percent). No significance level below 90 percent are used in practice, however it indicates a decreasing trend in FI crashes due to the ASCT implementation. For total and PDO crashes the CMG were very close to one, indicating no change in crash frequency.

\subsubsection{Three-Legged Intersections}

Out of the six intersections on this project, only one was a three-legged intersection. Due to this low number of available three-legged intersections, no CMF was computed. Therefore, more data is needed to compute a reliable CMF and make a clear statement of the ASCT effects on safety.

\subsubsection{All Intersections Combined}

The results presented in this section are based on all 6 intersections combined including three and four-legged intersections. Similar to the previous results, the single-vehicle crashes CMF alone was not developed due to the low number of crashes observed on the field. Results presented in Table 16 presents the project-level CMF for multiple-vehicle crashes.

Table 16. Signalized Intersection CMF Results and Standard Error

\begin{tabular}{|c|c|c|}
\hline Crash Severity & CMF & SE \\
\hline Total & 0.96 & 0.15 \\
\hline FI & 0.67 & 0.22 \\
\hline PDO & 1.04 & 0.18 \\
\hline
\end{tabular}

The results of the entire project follow the same trend of the four-legged intersection results because the observed crashes were predominately on four-legged intersections. The studied corridor only had one three-legged intersection which makes its impact much less significant. Nonetheless, as seen in Table 16, the trend still holds and the FI CMF is less than one. For multiple vehicle FI crashes in fourlegged intersections only, the CMF was also 0.67, which was not statistically significant at 95 percent confidence level (it was significant at 85 percent). No significance level below 90 percent are used in practice, however it indicates a decreasing trend in FI crashes due to the ASCT implementation. For total and PDO crashes the CMF were very close to one, indicating no change in crash frequency.

\subsubsection{Illinois SPF}

The results presented in this section (Illinois SPF Section) are computed using the Illinois specific SPF developed by Tegge et al. 2010. The Illinois SPFs do not differentiate between three and four-legged 
intersections, which means the CMFs are for all intersections combined. So, it may seem that the Illinois CMF are comparable to the CMF presented in the section ALL Intersections Combined, but actually they are not comparable. Even though Tegge et al called them FI crashes, they do not include type $C$ injuries. Thus, they are not comparable to the CMF developed for FI using the SPF in HSM. Nonetheless, they can still capture the trend in safety effects, if such a trend exists. The Illinois SPFs are for KAB (fatal plus type A plus type B injuries) crashes, only type $A$ injury crashes, and only type $B$ injury crashes. The results from this section are used to see if they support the results presented in sections 5.2.1 through 5.2.3. Table 17 presents the CMFs computed using Tegge's SPF.

Table 17. Urban Signalized Intersection CMF Results and Standard Error.

\begin{tabular}{|c|c|c|}
\hline Crash Severity & CMF & SE \\
\hline KAB & 0.68 & 0.29 \\
\hline Type A Injury & - & - \\
\hline Type B Injury & 0.87 & 0.41 \\
\hline
\end{tabular}

The CMF for type $A$ injury was not developed due to the low frequency of crashes in the before and after period. The KAB CMF was 0.68 very similar to the CMF computed with the models from the HSM. However, this CMF was only significant at 71 percent. As mentioned before, this confidence level is not used in practice but indicates a decreasing trend. The reason for this lower confidence level may be due to the model not considering type $C$ injury crashes which were slightly reduced. $A$ breakdown of the crashes per year per type and severity can be found in Appendix D.

In summary, the Illinois SPF did not differentiate among three and four-legged intersections, did not include type $\mathrm{C}$ crashes, and did not have models for PDO and total crashes. Instead, they were divided into KAB (i.e. Fatal, type $A$, and type $B$ injury crashes), type $A$ injury crashes, and type $B$ injury crashes. The $C M F$ for $K A B$ crashes was found to be 0.68 indicating a reduction in this type of crashes but was not found to be statistically significant at 95 percent confidence level. The type B injury CMF was 0.87, which was not significant at 95 percent confidence level. Lastly, the type A CMF was not computed due to the low crash frequency in the before and after periods.

\subsubsection{Pedestrian and Bike Crashes}

During the study period, there were zero pedestrian crashes and only one bike crash in 2012 across the entire corridor. This lack of pedestrian and bike crashes in both the before and after periods show that the system did not negatively affect the pedestrian and bicyclist safety. The pedestrian models and bike factor calibration were performed before the totality of the data was received.

\subsection{SHIFT IN PROPORTION}

HSM suggested using Wilcoxon Signed Rank test to see if it supports a shift in median value of the crashes from one intersection to another. The results for all crash types and crash severity are presented in Table 18 and Table 19, respectively. They indicate that there were no significant shifts in location (median) among the six intersections in the before and after period. The shift in proportions 
were computed as the median of the Walsh averages among all intersections (Hollander and Wolfe 2014). The tests were performed, but the sample sizes were very small (4 to 6); thus, the test results have limited utilities. Table 18 presents the results of the crash types tested (angle, rear end, sideswipe same direction, and turning crashes), while Table 19 presents the results of the crash severities tested (type $A$, type $B$, and type $C$ injury crashes). The proportions of crash types were taken relative to the total crashes, and the test performed for crash severities was taken relative to the Fl crashes instead of the total crashes.

Table 18. Wilcoxon Signed Rank Test Results for Crash Types

\begin{tabular}{|c|c|c|}
\hline Crash Type & Avg. Shift & p-value \\
\hline Angle & -0.042 & 0.81 \\
\hline Rear End & -0.045 & 0.81 \\
\hline $\begin{array}{c}\text { Sideswipe Same } \\
\text { Direction }\end{array}$ & -0.041 & 0.625 \\
\hline Turning & -0.053 & 0.78 \\
\hline
\end{tabular}

Table 19. Wilcoxon Signed Rank Test Results for Crash Severities

\begin{tabular}{|c|c|c|}
\hline Severity & Avg. Shift & p-value \\
\hline Type A & -0.18 & 0.62 \\
\hline Type B & 0.37 & 0.28 \\
\hline Type C & -0.28 & 0.62 \\
\hline
\end{tabular}

Wilcoxon Signed Ranked Test is a conservative test and unless the shift is extremely evident it does not produce statistically significant results when the sample size is small. In this project, the available data had at most six data points, and in some cases even 3 data points due to ties and absence of some crash severities at intersections. For these reasons, to test whether a specific crash type or severity was affected more than others, a paired t test was performed.

The paired t test was performed testing whether the crash frequency in the after period was significantly different than the average (18-month average) crash frequency in the before period. First, Tables 20 to 26 present all the crash types and severities studied per intersection, then Table 27 presents the results of the paired test.

Table 20. Intersections Angle Crashes per Year

\begin{tabular}{|c|c|c|c|c|c|c|c|}
\hline \multicolumn{2}{|c|}{} & \multicolumn{3}{|c|}{ Before (36 months) } & After (18 months) & \\
\hline Major Road & Minor Road & $\mathbf{2 0 1 2}$ & $\mathbf{2 0 1 3}$ & $\mathbf{2 0 1 4}$ & $\begin{array}{c}\text { May2015- } \\
\text { Dec2016 }\end{array}$ & $\begin{array}{c}\text { Jan2016- } \\
\text { Oct2016 }\end{array}$ & Total \\
\hline Neil St. & Stadium Dr. & 1 & 0 & 1 & 0 & 0 & 2 \\
\hline Neil St. & Kirby Ave. & 3 & 4 & 1 & 2 & 3 & 13 \\
\hline Neil St. & St. Mary's Rd. & 1 & 1 & 0 & 0 & 1 & 3 \\
\hline Neil St. & Devonshire Dr. & 0 & 0 & 0 & 0 & 0 & 0 \\
\hline Neil St. & Knollwood St. & 0 & 0 & 0 & 1 & 0 & 1 \\
\hline Neil St. & Windsor Rd. & 1 & 2 & 2 & 0 & 0 & 5 \\
\hline & Sum & 6 & 7 & 4 & 3 & 4 & 24 \\
\hline
\end{tabular}


Table 21. Intersections Rear End Crashes per Year

\begin{tabular}{|c|c|c|c|c|c|c|c|}
\hline \multicolumn{2}{|c|}{} & \multicolumn{3}{|c|}{ Before (36 months) } & After (18 months) & \\
\hline Major Road & Minor Road & $\mathbf{2 0 1 2}$ & $\mathbf{2 0 1 3}$ & $\mathbf{2 0 1 4}$ & $\begin{array}{c}\text { May2015- } \\
\text { Dec2016 }\end{array}$ & $\begin{array}{c}\text { Jan2016- } \\
\text { Oct2016 }\end{array}$ & Total \\
\hline Neil St. & Stadium Dr. & 3 & 1 & 2 & 3 & 1 & 10 \\
\hline Neil St. & Kirby Ave. & 9 & 10 & 7 & 5 & 5 & 36 \\
\hline Neil St. & St. Mary's Rd. & 1 & 2 & 3 & 5 & 1 & 12 \\
\hline Neil St. & Devonshire Dr. & 3 & 2 & 4 & 2 & 2 & 13 \\
\hline Neil St. & Knollwood St. & 2 & 0 & 4 & 2 & 1 & 9 \\
\hline Neil St. & Windsor Rd. & 3 & 7 & 2 & 2 & 3 & 17 \\
\hline & Sum & 21 & 22 & 22 & 19 & 13 & 97 \\
\hline
\end{tabular}

Table 22. Intersections Sideswipe Same Direction Crashes per Year

\begin{tabular}{|c|c|c|c|c|c|c|c|}
\hline \multicolumn{2}{|c|}{} & \multicolumn{3}{|c|}{ Before (36 months) } & After (18 months) & \\
\hline Major Road & Minor Road & $\mathbf{2 0 1 2}$ & $\mathbf{2 0 1 3}$ & $\mathbf{2 0 1 4}$ & $\begin{array}{c}\text { May2015- } \\
\text { Dec2016 }\end{array}$ & $\begin{array}{c}\text { Jan2016- } \\
\text { Oct2016 }\end{array}$ & Total \\
\hline Neil St. & Stadium Dr. & 1 & 0 & 0 & 0 & 0 & 1 \\
\hline Neil St. & Kirby Ave. & 1 & 1 & 1 & 0 & 3 & 6 \\
\hline Neil St. & St. Mary's Rd. & 0 & 0 & 0 & 0 & 1 & 1 \\
\hline Neil St. & Devonshire Dr. & 1 & 1 & 0 & 0 & 0 & 2 \\
\hline Neil St. & Knollwood St. & 0 & 0 & 0 & 0 & 0 & 0 \\
\hline Neil St. & Windsor Rd. & 1 & 0 & 1 & 0 & 0 & 2 \\
\hline & Sum & 4 & 2 & 2 & 0 & 4 & 12 \\
\hline
\end{tabular}


Table 23. Intersections Turning Crashes per Year

\begin{tabular}{|c|c|c|c|c|c|c|c|}
\hline \multicolumn{2}{|c|}{} & \multicolumn{3}{|c|}{ Before (36 months) } & After (18 months) & \\
\hline Major Road & Minor Road & $\mathbf{2 0 1 2}$ & $\mathbf{2 0 1 3}$ & $\mathbf{2 0 1 4}$ & $\begin{array}{c}\text { May2015- } \\
\text { Dec2016 }\end{array}$ & $\begin{array}{c}\text { Jan2016- } \\
\text { Oct2016 }\end{array}$ & Total \\
\hline Neil St. & Stadium Dr. & 1 & 2 & 3 & 0 & 0 & 6 \\
\hline Neil St. & Kirby Ave. & 6 & 2 & 4 & 4 & 2 & 18 \\
\hline Neil St. & St. Mary's Rd. & 0 & 1 & 1 & 1 & 3 & 6 \\
\hline Neil St. & Devonshire Dr. & 1 & 0 & 0 & 1 & 0 & 2 \\
\hline Neil St. & Knollwood St. & 1 & 0 & 1 & 0 & 0 & 2 \\
\hline Neil St. & Windsor Rd. & 4 & 6 & 3 & 3 & 4 & 20 \\
\hline & Sum & 13 & 11 & 12 & 9 & 9 & 54 \\
\hline
\end{tabular}

Table 24. Intersections Type A Injury Crashes per Year

\begin{tabular}{|c|c|c|c|c|c|c|c|}
\hline \multicolumn{2}{|c|}{} & \multicolumn{3}{|c|}{ Before (36 months) } & After (18 months) & \\
\hline Major Road & Minor Road & $\mathbf{2 0 1 2}$ & $\mathbf{2 0 1 3}$ & $\mathbf{2 0 1 4}$ & $\begin{array}{c}\text { May2015- } \\
\text { Dec2016 }\end{array}$ & $\begin{array}{c}\text { Jan2016- } \\
\text { Oct2016 }\end{array}$ & Total \\
\hline Neil St. & Stadium Dr. & 1 & 2 & 0 & 0 & 0 & 3 \\
\hline Neil St. & Kirby Ave. & 0 & 0 & 1 & 0 & 0 & 1 \\
\hline Neil St. & St. Mary's Rd. & 0 & 0 & 0 & 1 & 0 & 1 \\
\hline Neil St. & Devonshire Dr. & 0 & 0 & 0 & 0 & 0 & 0 \\
\hline Neil St. & Knollwood St. & 0 & 0 & 2 & 0 & 0 & 2 \\
\hline Neil St. & Windsor Rd. & 2 & 0 & 0 & 0 & 0 & 2 \\
\hline & Sum & 3 & 2 & 3 & 1 & 0 & 9 \\
\hline
\end{tabular}

Table 25. Intersections Type B Injury Crashes per Year

\begin{tabular}{|c|c|c|c|c|c|c|c|}
\hline \multicolumn{2}{|c|}{} & \multicolumn{3}{|c|}{ Before (36 months) } & After (18 months) & \\
\hline Major Road & Minor Road & $\mathbf{2 0 1 2}$ & $\mathbf{2 0 1 3}$ & $\mathbf{2 0 1 4}$ & $\begin{array}{c}\text { May2015- } \\
\text { Dec2016 }\end{array}$ & $\begin{array}{c}\text { Jan2016- } \\
\text { Oct2016 }\end{array}$ & Total \\
\hline Neil St. & Stadium Dr. & 0 & 0 & 0 & 0 & 0 & 0 \\
\hline Neil St. & Kirby Ave. & 2 & 1 & 3 & 1 & 1 & 8 \\
\hline Neil St. & St. Mary's Rd. & 0 & 1 & 1 & 1 & 0 & 3 \\
\hline Neil St. & Devonshire Dr. & 0 & 0 & 0 & 1 & 0 & 1 \\
\hline Neil St. & Knollwood St. & 0 & 0 & 0 & 0 & 1 & 1 \\
\hline Neil St. & Windsor Rd. & 1 & 0 & 3 & 0 & 1 & 5 \\
\hline & Sum & 3 & 2 & 7 & 3 & 3 & 18 \\
\hline
\end{tabular}


Table 26. Intersections Type C Injury Crashes per Year

\begin{tabular}{|c|c|c|c|c|c|c|c|}
\hline \multicolumn{2}{|c|}{} & \multicolumn{3}{|c|}{ Before (36 months) } & After (18 months) & \\
\hline Major Road & Minor Road & $\mathbf{2 0 1 2}$ & $\mathbf{2 0 1 3}$ & $\mathbf{2 0 1 4}$ & $\begin{array}{c}\text { May2015- } \\
\text { Dec2016 }\end{array}$ & $\begin{array}{c}\text { Jan2016- } \\
\text { Oct2016 }\end{array}$ & Total \\
\hline Neil St. & Stadium Dr. & 0 & 0 & 1 & 0 & 0 & 1 \\
\hline Neil St. & Kirby Ave. & 4 & 3 & 2 & 1 & 0 & 10 \\
\hline Neil St. & St. Mary's Rd. & 1 & 0 & 1 & 2 & 0 & 4 \\
\hline Neil St. & Devonshire Dr. & 1 & 1 & 0 & 0 & 0 & 2 \\
\hline Neil St. & Knollwood St. & 0 & 0 & 0 & 0 & 0 & 0 \\
\hline Neil St. & Windsor Rd. & 1 & 0 & 2 & 1 & 1 & 5 \\
\hline & Sum & 7 & 4 & 6 & 4 & 1 & 22 \\
\hline
\end{tabular}

Table 27. Paired t Test Results

\begin{tabular}{|c|c|c|c|c|}
\hline $\begin{array}{c}\text { Crash } \\
\text { Type/Severity }\end{array}$ & $\begin{array}{c}\text { Crash Frequency } \\
\text { Before Period } \\
\text { (crashes/18month) }\end{array}$ & $\begin{array}{c}\text { Crash Frequency } \\
\text { After Period } \\
\text { (crashes/18month) }\end{array}$ & $\begin{array}{c}\text { Avg. Difference } \\
\text { per intersection } \\
\text { (crashes/18month) }\end{array}$ & p-value \\
\hline Angle & 8.5 & 7 & -0.25 & 0.67 \\
\hline Rear End & 32.5 & 32 & -0.83 & 0.92 \\
\hline Sideswipe Same Direction & 4 & 4 & 0.00 & 1.00 \\
\hline Turning & 18 & 18 & 0.00 & 1.00 \\
\hline Type A & 4 & 1 & -0.5 & 0.22 \\
\hline Type B & 6 & 6 & 0.0 & 1.00 \\
\hline Type C & 8.5 & 5 & -0.58 & 0.44 \\
\hline
\end{tabular}

The results from the paired test show mostly decreasing trends in crash type and severity as well as no change in sideswipe same direction, turning, and type B injury crashes. From the crash types, the angle and rear end crashes showed reductions. From the crash severities, type $A$ and type $C$ injury crashes also showed a reduction. However, none of the reductions are statistically significant with the highest confidence level being 78 percent. 


\section{CHAPTER 6: CONCLUSION AND RECOMMENDATIONS}

This report evaluated the safety effects of the adaptive signal system SynchroGreen (an ASCT system). For multiple-vehicle FI crashes at all intersections (four-legged and three-legged combined), the CMF was 0.67 , which was not statistically significant at 95 percent confidence level (it was significant at 87 percent). For four-legged-only intersections the CMF was 0.67 as well, which was not significant with 95 percent confidence (it was significant at 85 percent). The 87 and 85 percent are not confidence levels used in practice, however they clearly indicate a decreasing trend in Fl crashes due to the implementation of ASCT. For the three-legged intersection there was not adequate data to develop CMFs. For PDO and total crashes, all CMF computed were close to one indicating no crash reduction due to the implementation of ASCT. The CMF developed with the SPF from Illinois KAB crashes (fatal, type A injury, and type B injury crashes combined) was found to be 0.68 , which was not significant at 95 percent confidence level (it was significant at 71 percent indicating a decreasing trend in these types of crashes). Lastly, the CMF for type B injury crashes only was 0.87 , which was not found to be statistically significant at any meaningful confidence level.

Wilcoxon Signed Ranked tests were performed but due to small sample size they were not relied on assessing if there was a shift in location of crashes. For this reason, paired t-test was performed to further explore which crashes were most affected by the reduction due to the ASCT implementation. The results from the Paired t-test showed no reduction in sideswipe same direction, turning, and type $B$ injury crashes. However, angle, rear end, type $A$ and type $C$ injury crashes showed slight decreases that were not significant.

The assumption of medium level pedestrian volume for mid-sized cities was supported using local data. In the calibration of the pedestrian SPFs, the local pedestrian volume data that showed an average value of 727 pedestrians per day which is very close to the medium level of pedestrian activity which is 700 pedestrians per day in HSM.

It is recommended that in the future studies the ASCT's long-term safety effects (multi-year) should be studied. Furthermore, to differentiate the ASCT effects on three-legged and four-legged intersections, the system should be implemented at higher number of three-legged signalized intersections. 


\section{REFERENCES}

AASHTO Highway Safety Manual Illinois User Guide. Report 0439-15. Illinois Department of Transportation, 2014.

Alluri, P., D. Saha, and A. Gan. Minimum Sample Sizes for Estimating Reliable Highway Safety Manual (HSM) Calibration Factors. Journal of Transportation Safety and Security, 2016. 1: 56-74.

American Association of State Highway Transportation Officials. Highway Safety Manual (HSM). AASHTO, 2010.

Bahar, G. User's Guide to Develop Highway Safety Manual Safety Performance Function Calibration Factors. Publication: HR 20-7(332). National Cooperative Highway Research Program, Transportation Research Board, 2014.

Beattie O. gmaps-radius. github.com/obeattie/gmaps-radius. Accessed Jan. 20, 2018.

Benekohal R., Garshasebi B., Liu X., and Jeon H. Evaluation of Adaptive Signal Control TechnologyVolume 2: Comparison of Base Condition to the First Year After Implementation. Report: FHWAICT-18-055. Illinois Center for Transportation, 2018.

Cheek, M., Wetzel C., and Dickson C. SynchroGreen Real-Time Adaptive Traffic Control System Seminole County Deployment. Presented at ITE 2012 Annual Meeting \& Exhibit, Georgia, 2012.

Dutta U., Bodke S., Dara B., and Lynch J. Safety Evaluation of SCATS Control Systems. Report No: RC1545. Michigan Ohio University Transportation Center, 2010.

Federal Highway Administration. Summary of State SPF Calibration and Development Efforts. June of 2016. http://www.cmfclearinghouse.org/resources_spf.cfm. Accessed Jul. 2, 2018.

Fink, J., Kwigizile, V., \& Oh, J. S. Quantifying the Impact of Adaptive Traffic Control Systems on Crash Frequency and Severity: Evidence from Oakland County, Michigan. Journal of Safety Research, 2016. 57: 1-7.

Hauer, E. The Art of Regression Modeling in Road Safety. New York: Springer, 2015.

Hicks B., and Carter M. Chapter 3: What Have We Learned About ITS? Arterial Management. Report: FHWA-OP-01-006. Federal Highway Administration, 2000.

Hocherman I., Hakkert A., and Bar-Ziv J. Estimating the Daily Volume of Crossing Pedestrians from Short-Counts. Transportation Research Record: Journal of the Transportation Research Board, 1988. 1168: 31-38.

Hollander M., Wolfe D., and Chicken E. Nonparametric Statistical Methods. John Wiley \& Sons, Inc., New Jersey, 2014.

Illinois Technology Transfer Center. Illinois Department of Transportation. http://apps.dot.illinois.gov/gist2/. Accessed Jul. 25, 2018.

Khattak Z., Magalotti M., and Fontaine M. Estimating Safety Effects of Adaptive Signal Control Technology Using the Empirical Bayes Method. Journal of Safety Research, 2018. 64: 121-128.

Lodes M., and Benekohal R. Safety Benefits of Implementing Adaptive Signal Control Technology: 
Survey Results. Report: FHWA-ICT-12-020. Illinois Center for Transportation, 2013.

Lyon C., Persaud B., Gross F. The Calibrator- An SPF Calibration Assessment Tool. Report No. FHWASA-17-016. Federal Highway Administration Office of Safety, 2016.

Ma, J., Fontaine, M. D., Zhou, F., Hale, D. K., \& Clements, M. O. Estimation of the Safety Effects of an Adaptive Traffic Signal Control System. ASCE Library Journal of Transportation Engineering, 2016.

Rawoof Shaik, M. A., Liu X., and Benekohal, R., Evaluation of Adaptive Signal Control TechnologyVolume 1: Before-Conditions Data Collection and Analysis. Report: FHWA-ICT-17-008. Illinois Center for Transportation, 2017.

Shin, H., Y. Lee, and S. Dadvar. The Development of Local Calibration Factors for Implementing the Highway Safety Manual in Maryland. Report No. MD-14-SP209B4J. Maryland State Highway Administration, 2014.

Shirazi, M., D. Lord, and S. Geedipally. Sample-size Guidelines for Recalibrating Crash Prediction Models: Recommendations for the Highway Safety Manual. Accident Analysis and Prevention, 2016, 93: 160-168.

So, J., A. Stevanovic, E. Posadas, and R. Awwad. Field Evaluation of a SynchroGreen Adaptive Signal System. ASCE Library Journal of Transportation Engineering, 2014.

Srinivasan, S., P. Haas, N. S. Dhakar, R. Hormel, D. Torbic, and D. Harwood. Development and Calibration of Highway Safety Manual Equations for Florida Conditions. Report No. TRC-FDOT-9 82013-2011. Florida Department of Transportation, 2011.

Stevanovic, A., Kergaye C., and Haigwood, J. Assessment of Surrogate Safety Benefits of an Adaptive Traffic Control System. Presented at 3rd international conference on road safety and simulation, 2011.

Sun, C., P. Edara, H. Brown, B. Claros, and K. Nam. Calibration of the Highway Safety Manual for Missouri, Addendum. Report No. cmr14-007 (addendum). Missouri Department of Transportation, 2014.

Tegge R. A., Jo J., and Ouyang Y. Development and Application of Safety Performance Functions for Illinois. Report No. FHWA-ICT-10-066. Illinois Department of Transportation, 2010.

Trafficware Group, Inc. Baytown, TX Case Study. http://www.trafficware.com/uploads/2/2/2/5/22256874/baytown_adaptive_case_study.pdf. Accessed Jul. 25, 2018.

Trafficware Group, Inc. Study Brief: Galveston, TX Case Study. http://www.trafficware.com/uploads/2/2/2/5/22256874/galveston-case-study.pdf. Accessed Jul. 25, 2018.

Trafficware Group, Inc. Study Brief: Brevard County, FL. http://www.trafficware.com/uploads/2/2/2/5/22256874/brevard-county-case-study.pdf Accessed Jul. 25, 2018.

Trafficware. SynchroGreen Real-time Adaptive Control System. September of 2012. http://www.trafficware.com/adaptive-traffic-control.html. Accessed Jun. 15, 2018. 
Xie, F., K. Gladhill, K. Dixon, and C. Monsere. Calibration of Highway Safety Manual Predictive Models for Oregon State Highways. Transportation Research Record: Journal of the Transportation Research Board, 2011. No. 2241, pp. 19-28.

Xie, Y., Chen C. Calibration of Safety Performance Functions for Massachusetts Urban and Suburban Intersections. Report No. UMTC 16.01. Massachusetts Department of Transportation, 2016. 


\section{APPENDIX A}

The following are the CURE plots for all SPFs calibrated. All plots were made having the cumulative residual in the $\mathrm{Y}$ axis and the number of predicted crashes after calibration in the $\mathrm{x}$ axis.

\section{FOUR-LEGGED INTERSECTIONS}

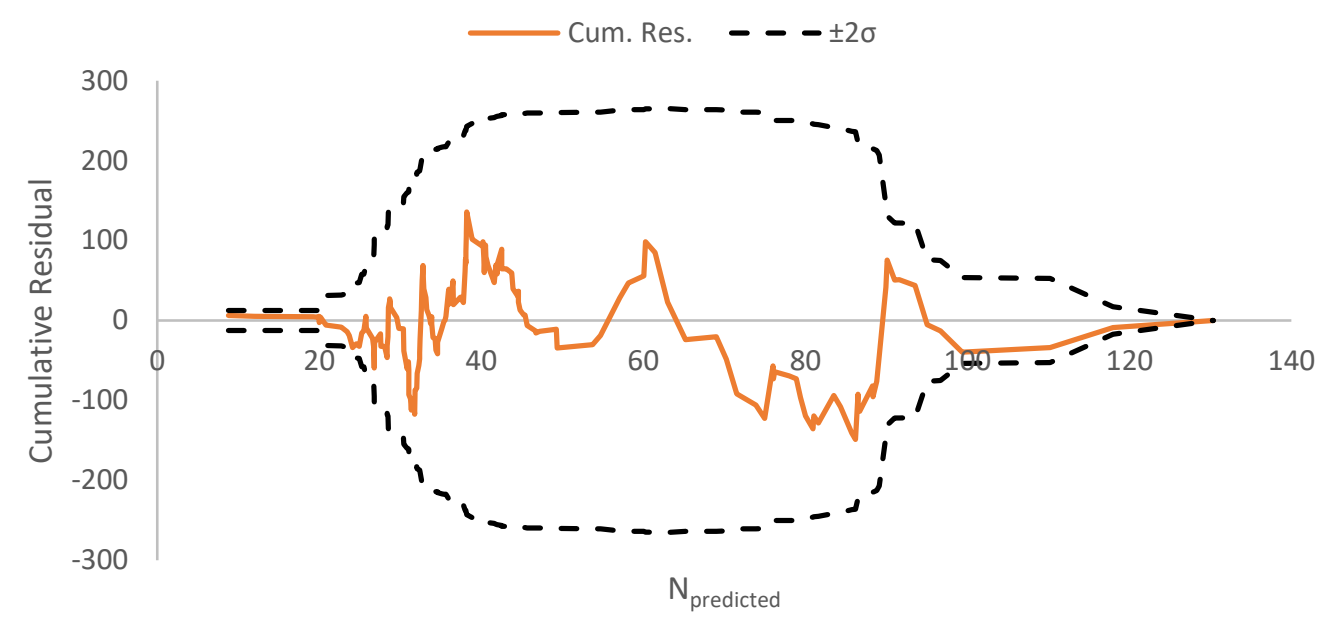

Figure A1. CURE plot for total multiple-vehicle crashes for four-legged intersections as a function of $\mathbf{N}_{\text {predicted. }}$

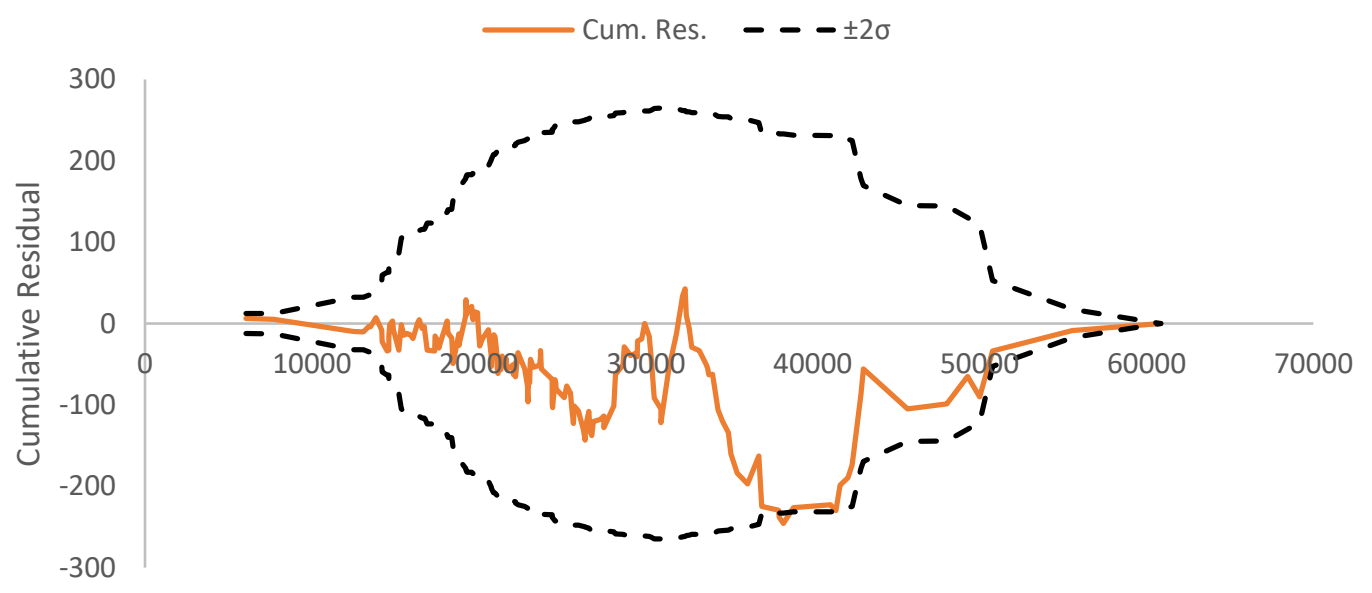

AADT minor + AADT major

Figure A2. CURE plot for total multiple-vehicle crashes for four-legged intersections as a function of total AADT. 


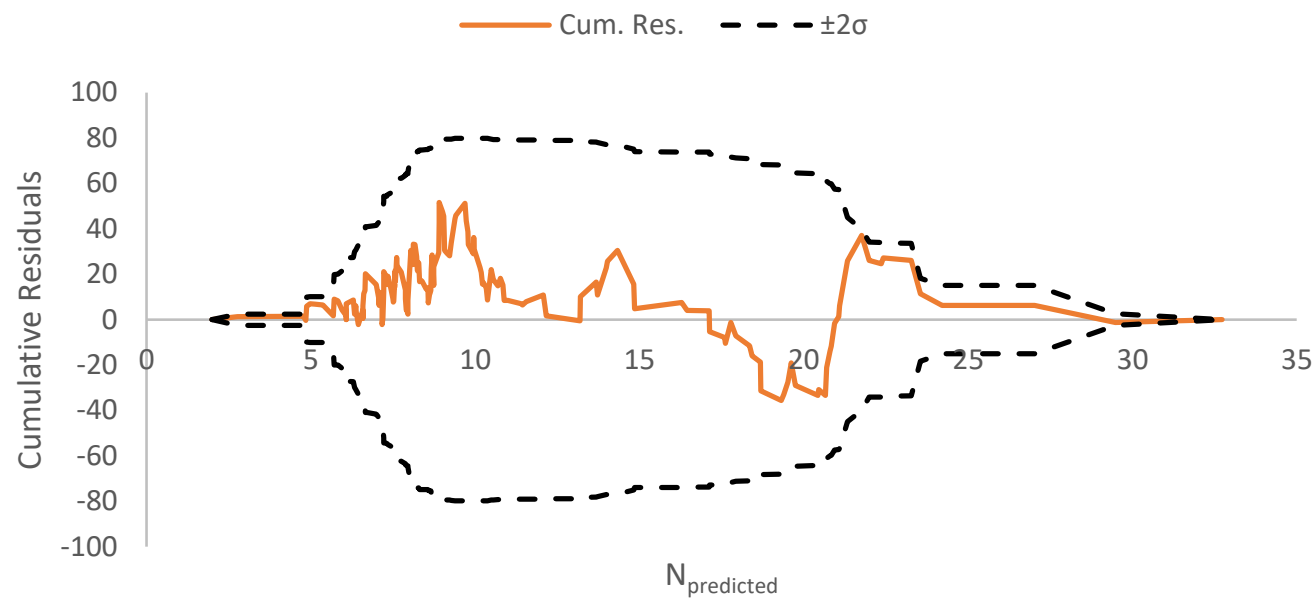

Figure A3. CURE Plot for fatal and injury multiple-vehicle crashes for four-legged intersections as a function of $\mathbf{N}_{\text {predicted. }}$

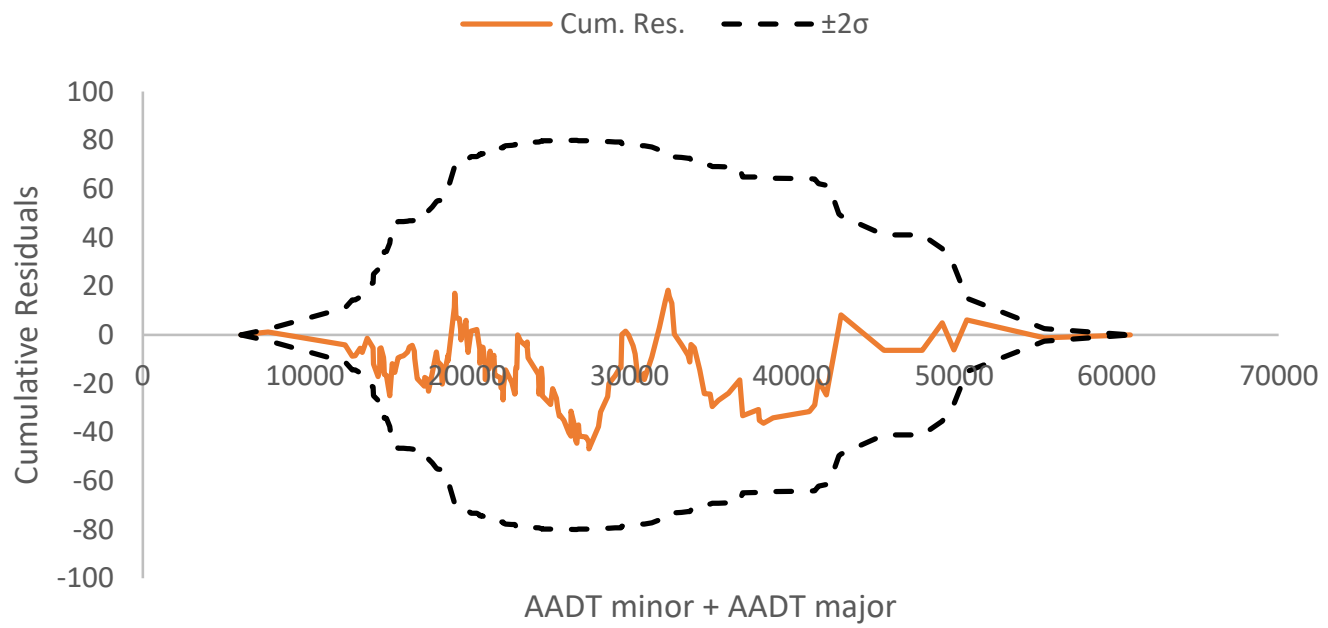

Figure A4. CURE Plot for fatal and injury multiple-vehicle crashes for four-legged intersections as a function of total AADT. 
Cum. Res. $\quad-\quad-\quad \pm 2 \sigma$

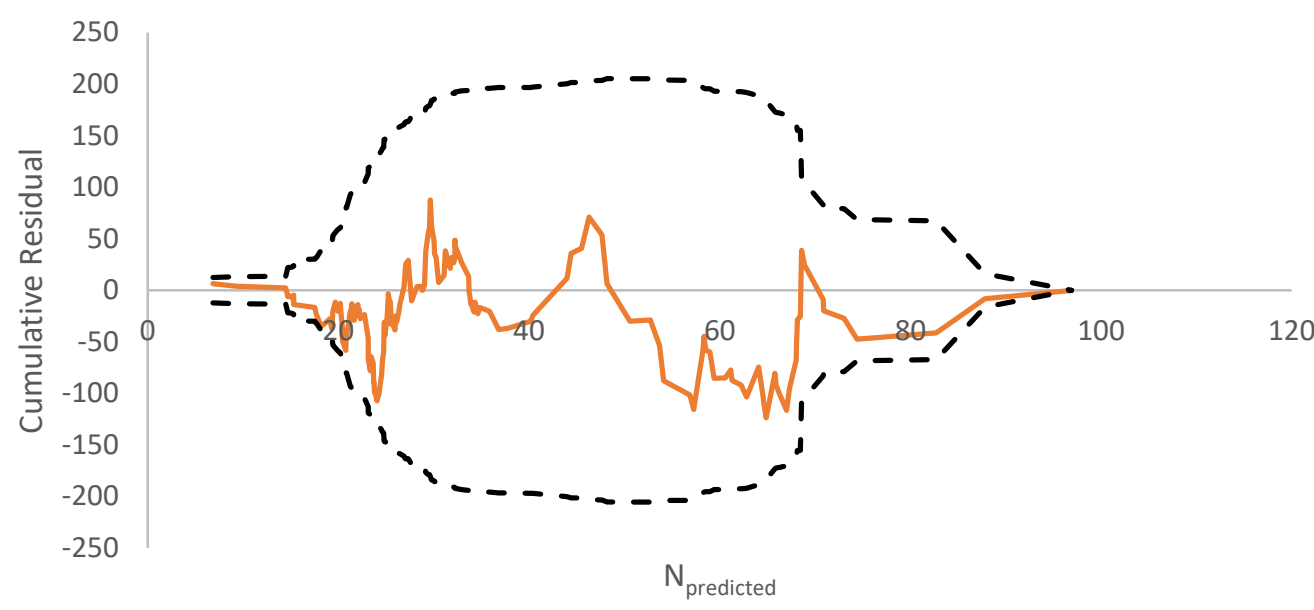

Figure A5. CURE Plot for PDO multiple-vehicle crashes for four-legged intersections as a function of $\mathbf{N}_{\text {predicted. }}$

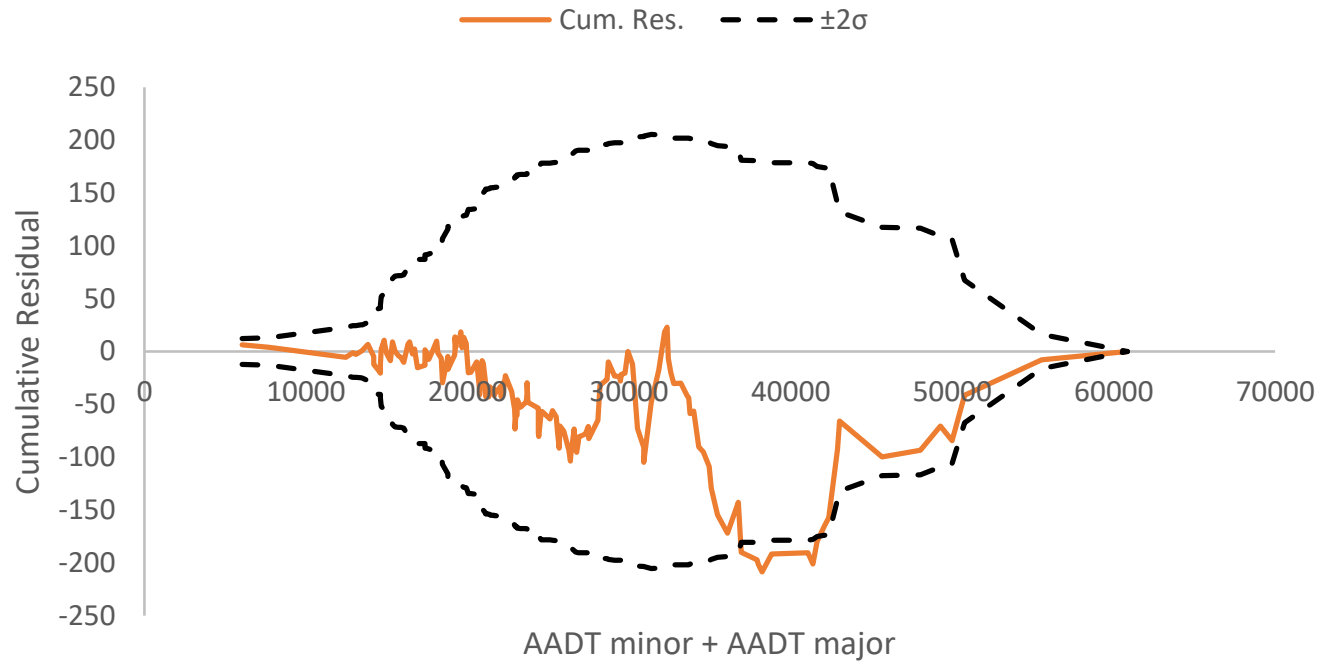

Figure A6. CURE Plot for PDO multiple-vehicle crashes for four-legged intersections as a function of total AADT. 


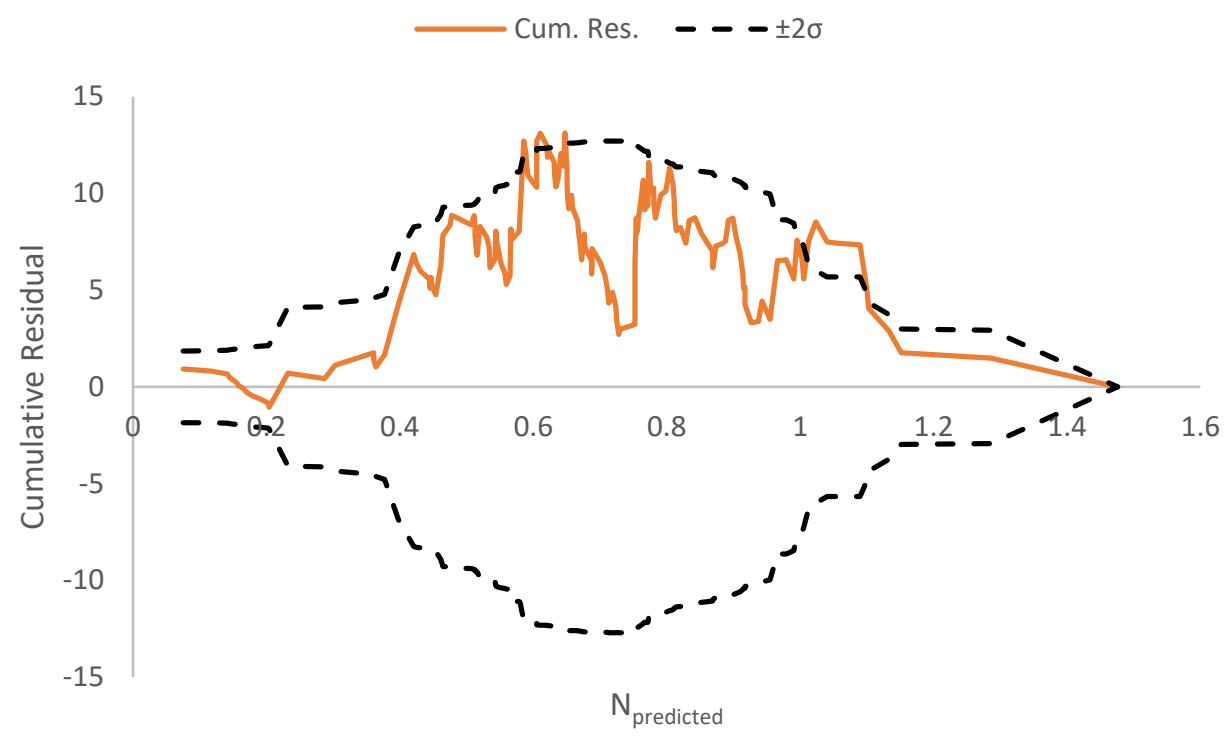

Figure A7. CURE Plot for Pedestrian Crashes for four-legged intersections as a function of $\mathbf{N}_{\text {predicted. }}$

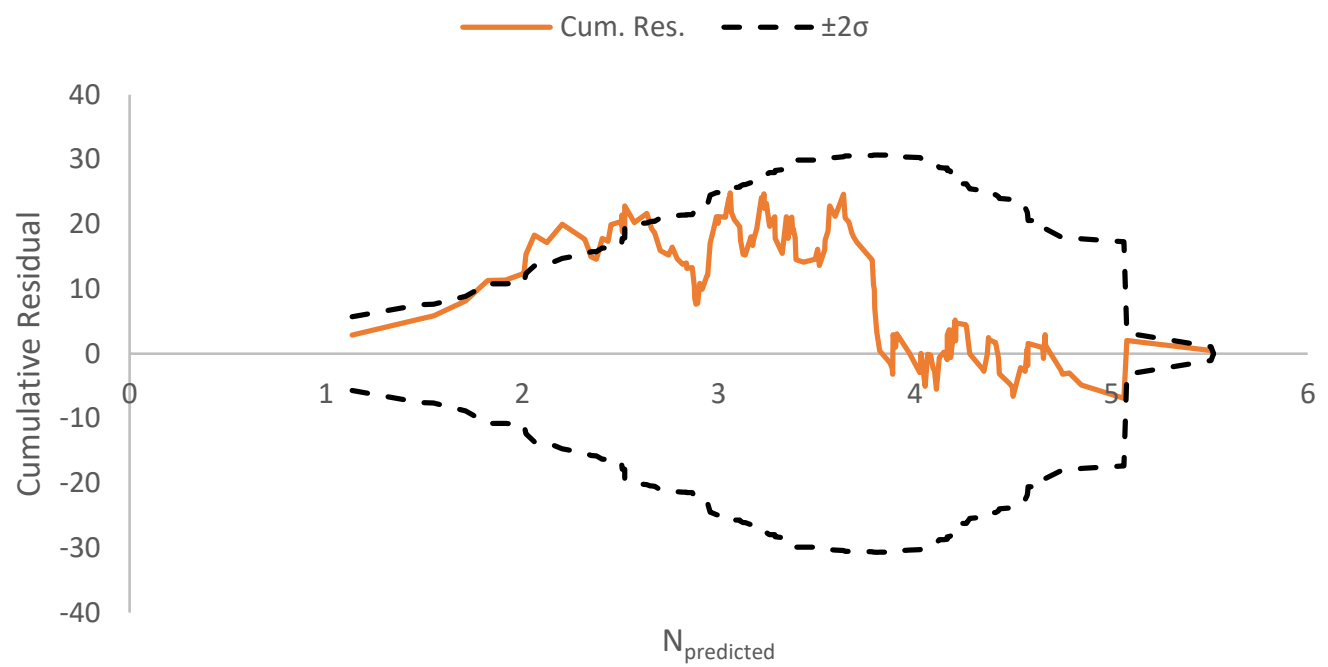

Figure A8. CURE plot for total single-vehicle crashes for four-legged intersections as a function of N predicted. 


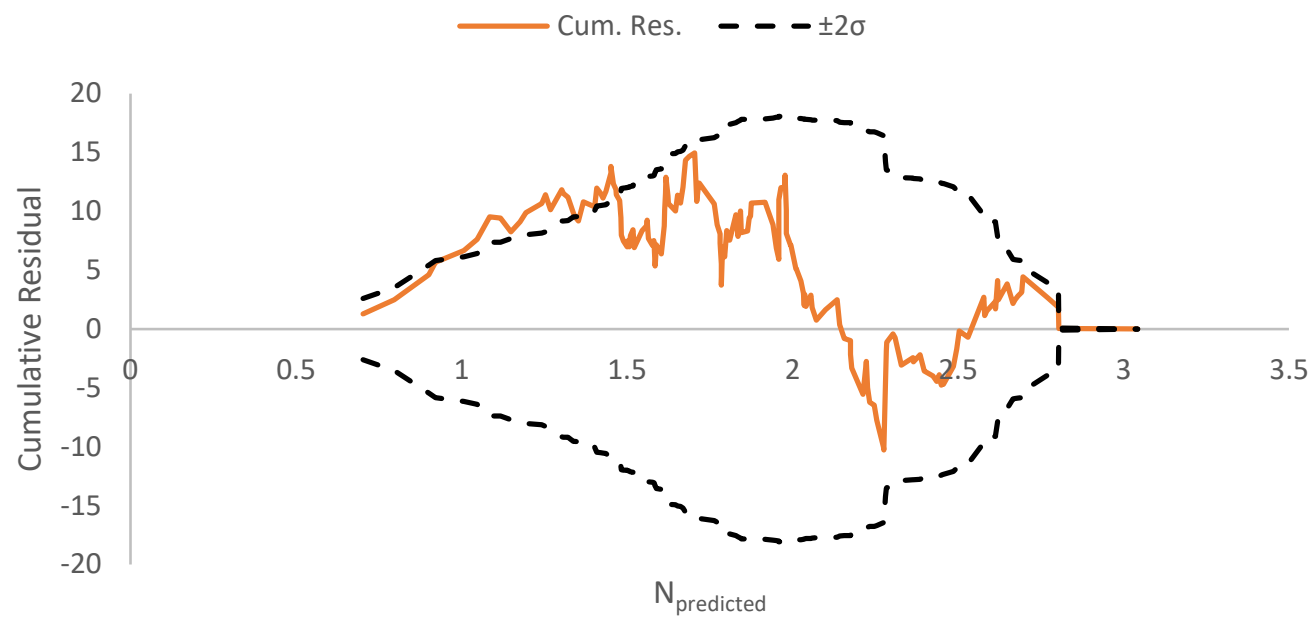

Figure A9. CURE plot for fatal and injury single-vehicle crashes four-legged intersections as a function of $\mathbf{N}_{\text {predicted. }}$

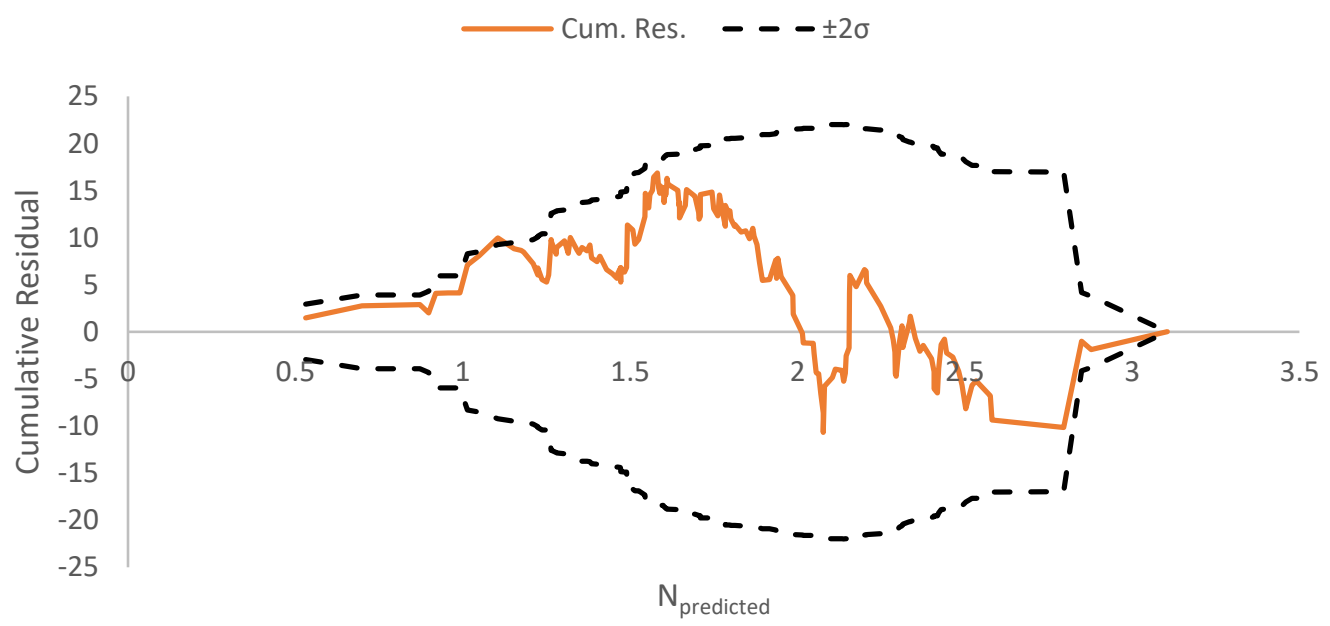

Figure A10. CURE plot for PDO single-vehicle crashes four-legged intersections as a function of N predicted. 


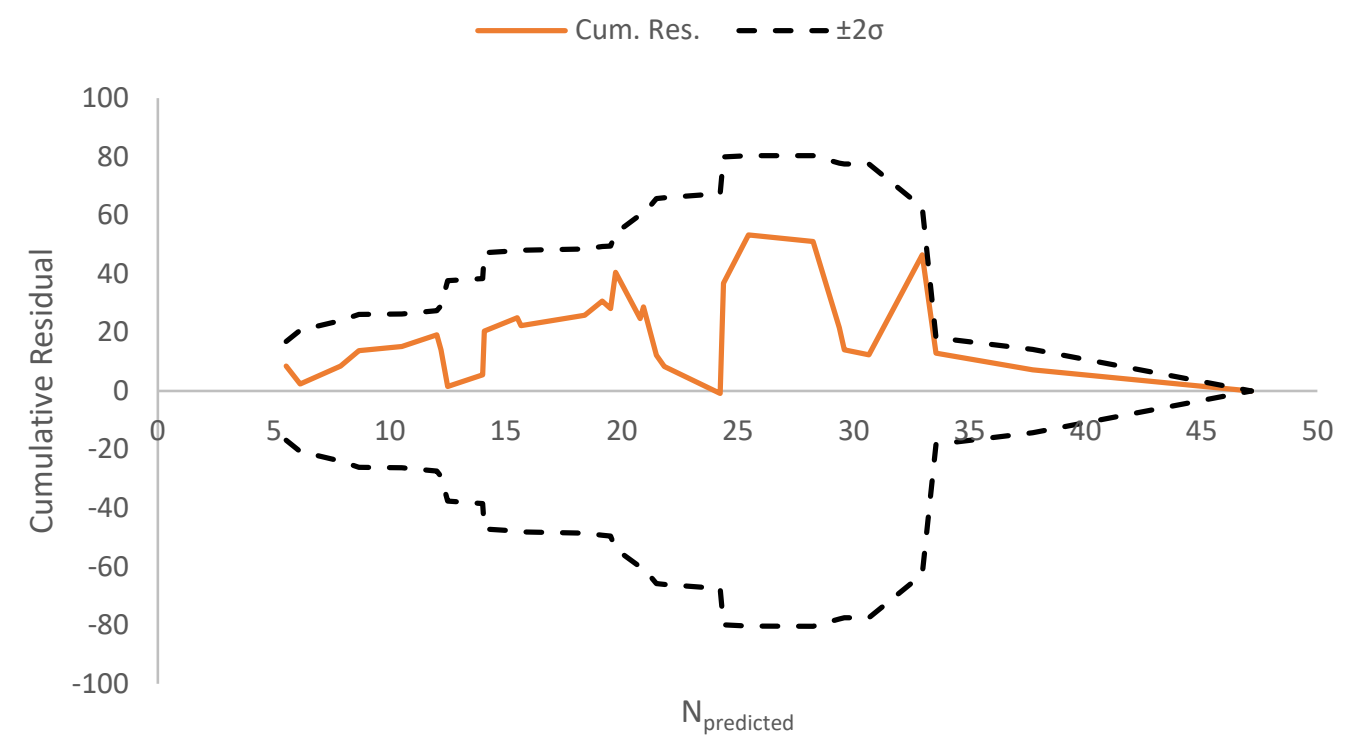

Figure A11. CURE plot for total multiple-vehicle crashes for three-legged intersections as a function of $\mathbf{N}_{\text {predicted. }}$

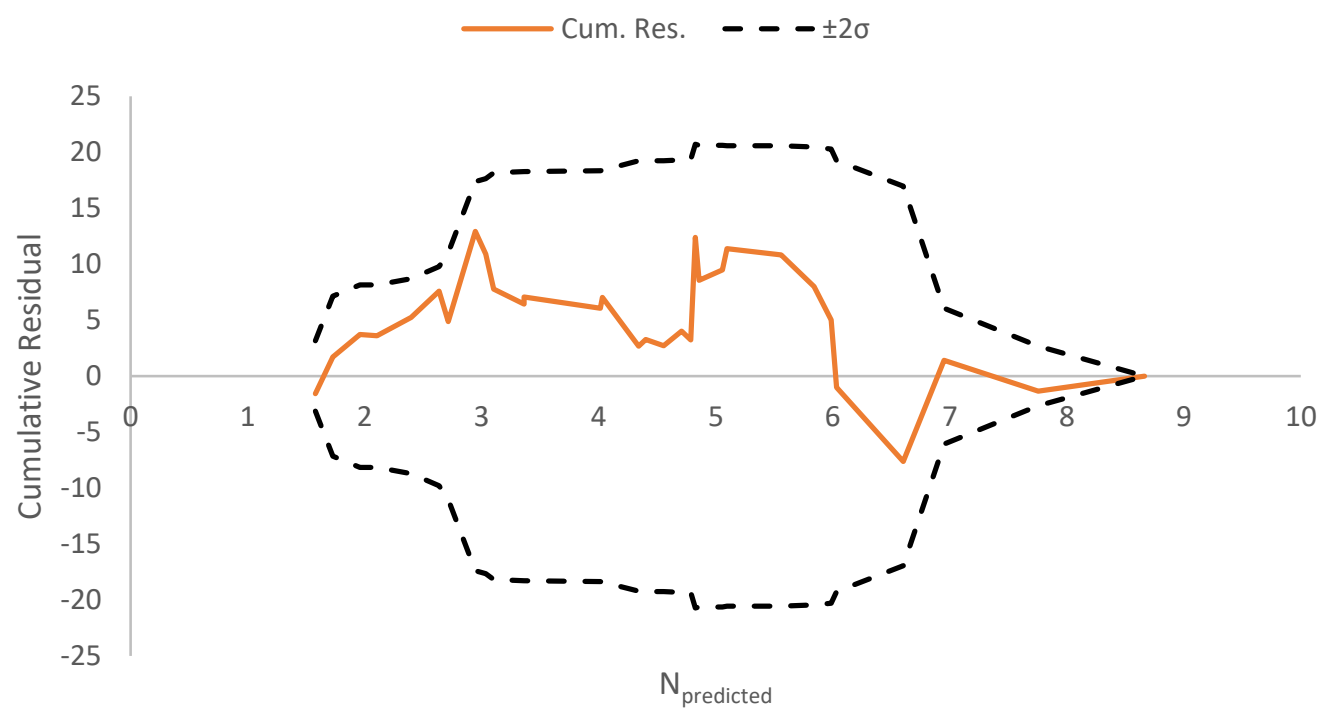

Figure A12. CURE plot for fatal and injury multiple-vehicle crashes for three-legged intersections as a function of $\mathbf{N}_{\text {predicted. }}$ 


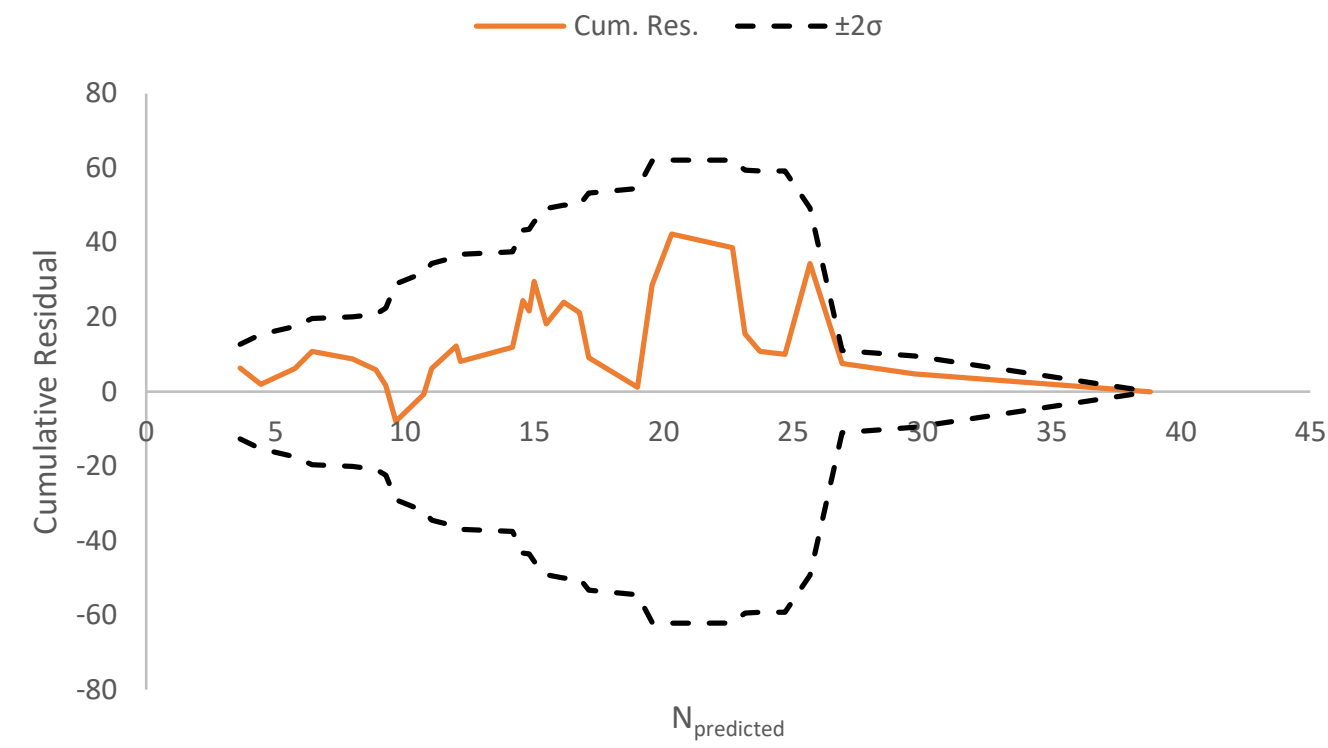

Figure A13. CURE plot PDO multiple-vehicle crashes for three-legged intersections as a function of N predicted.

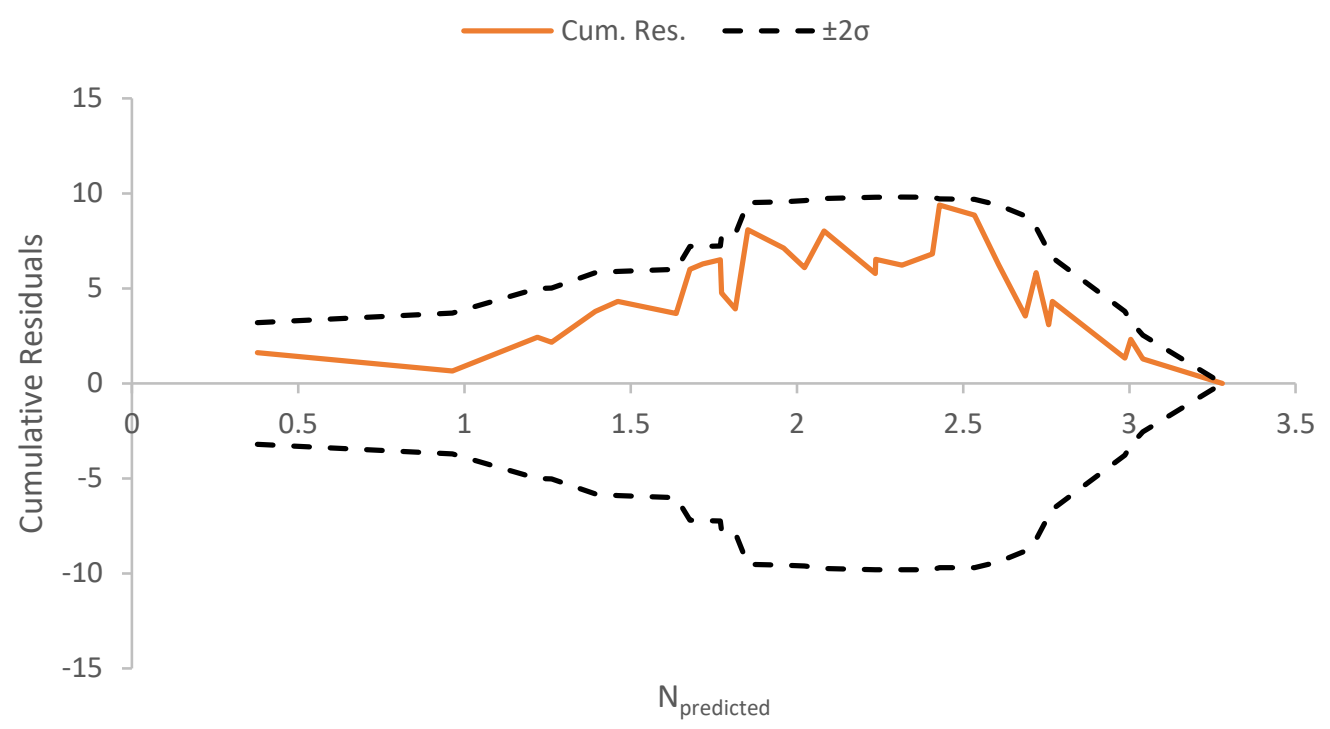

Figure A14. CURE plot total single-vehicle crashes for three-legged intersections as a function of N predicted. 


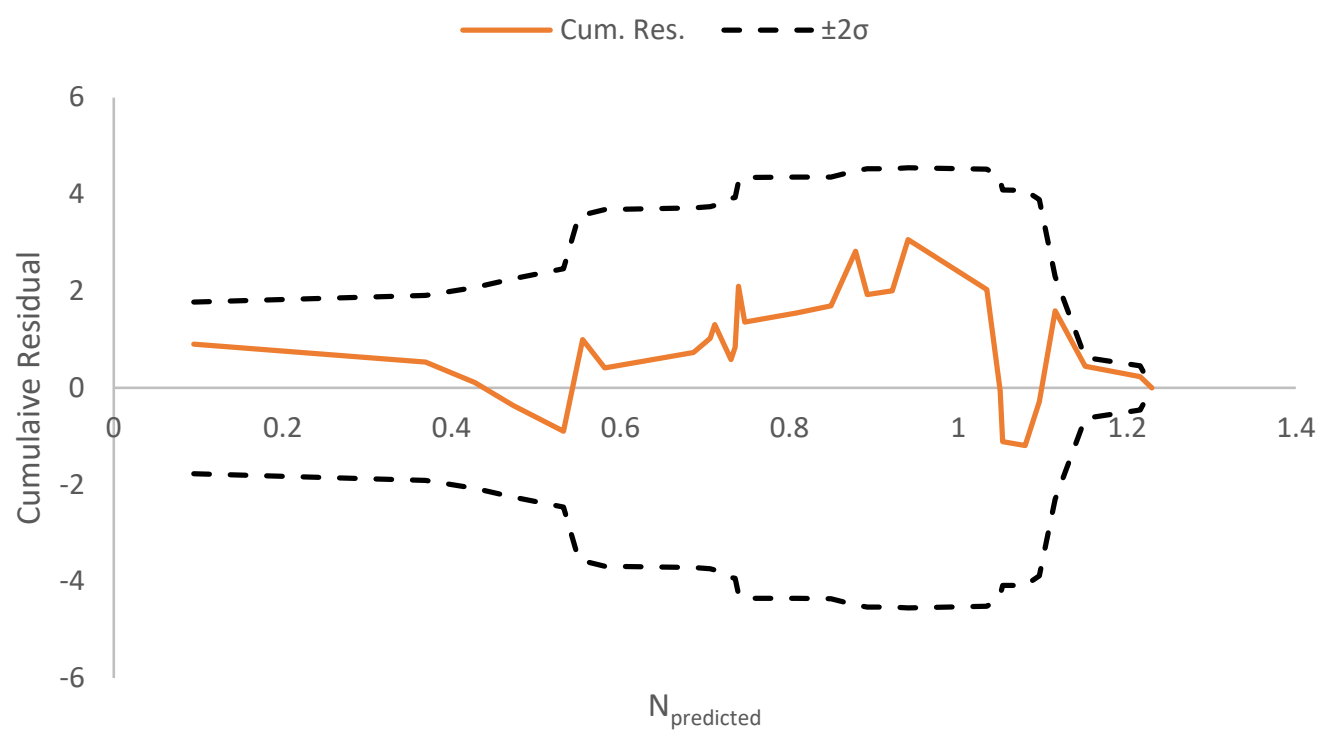

Figure A15. CURE plot fatal and injury single-vehicle crashes for three-legged intersections as a function of $\mathbf{N}_{\text {predicted. }}$

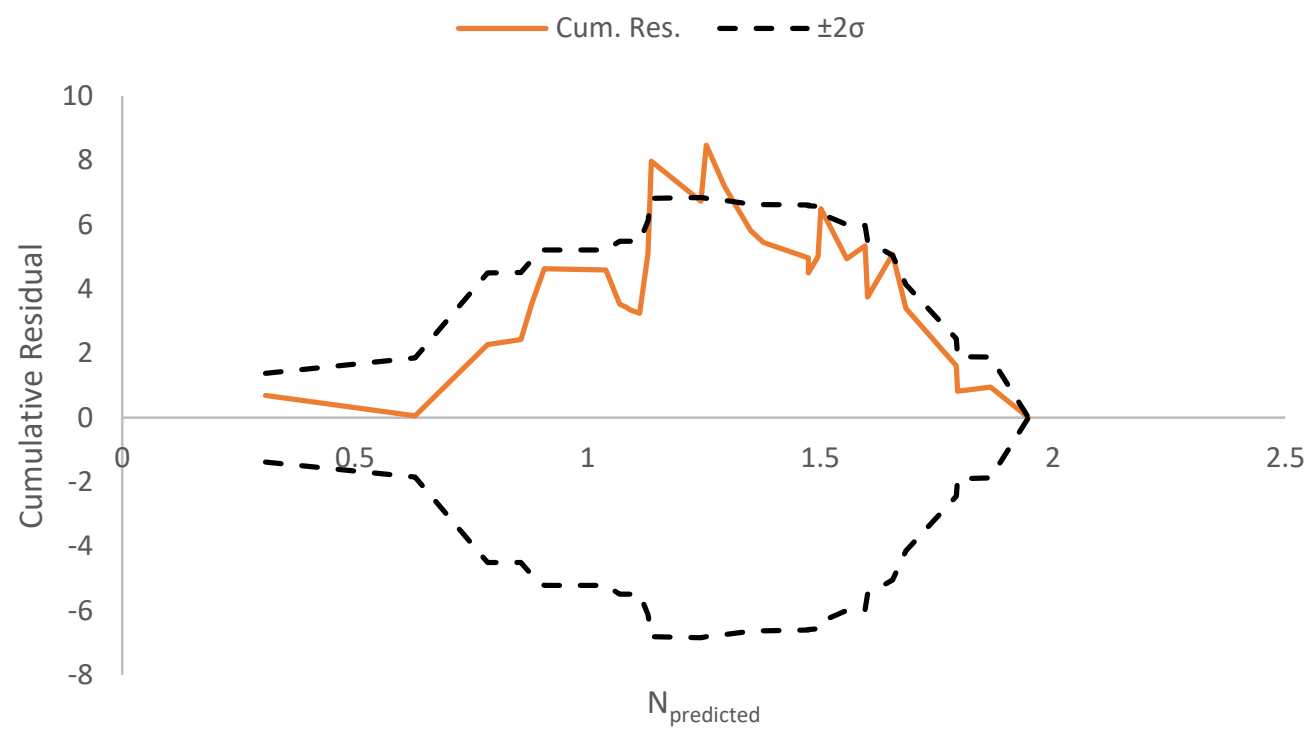

Figure A16. CURE plot PDO single-vehicle crashes for three-legged intersections as a function of N predicted. 


\section{ILLINOIS SPFS}

In the Illinois SPFs, both three and four-legged intersections were combined to perform a single calibration. The results are presented below.

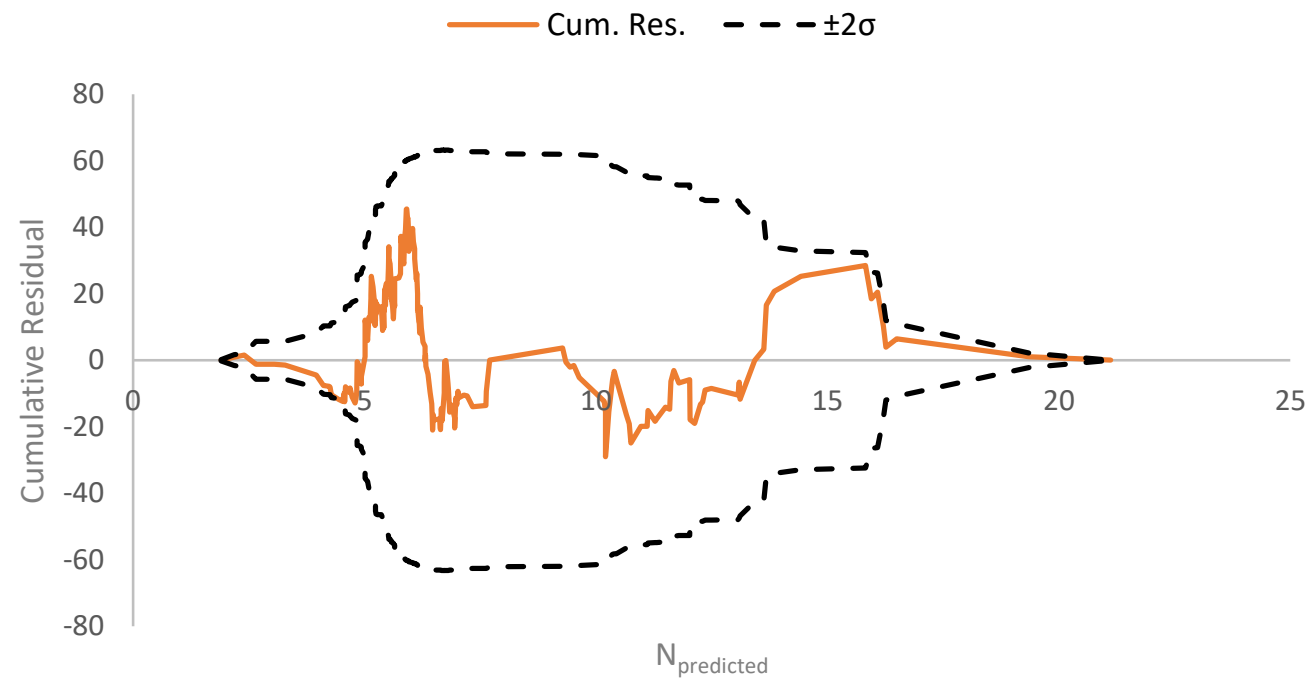

Figure A17. CURE Plot for fatal and injury crashes for urban signalized intersections as a function of N predicted.

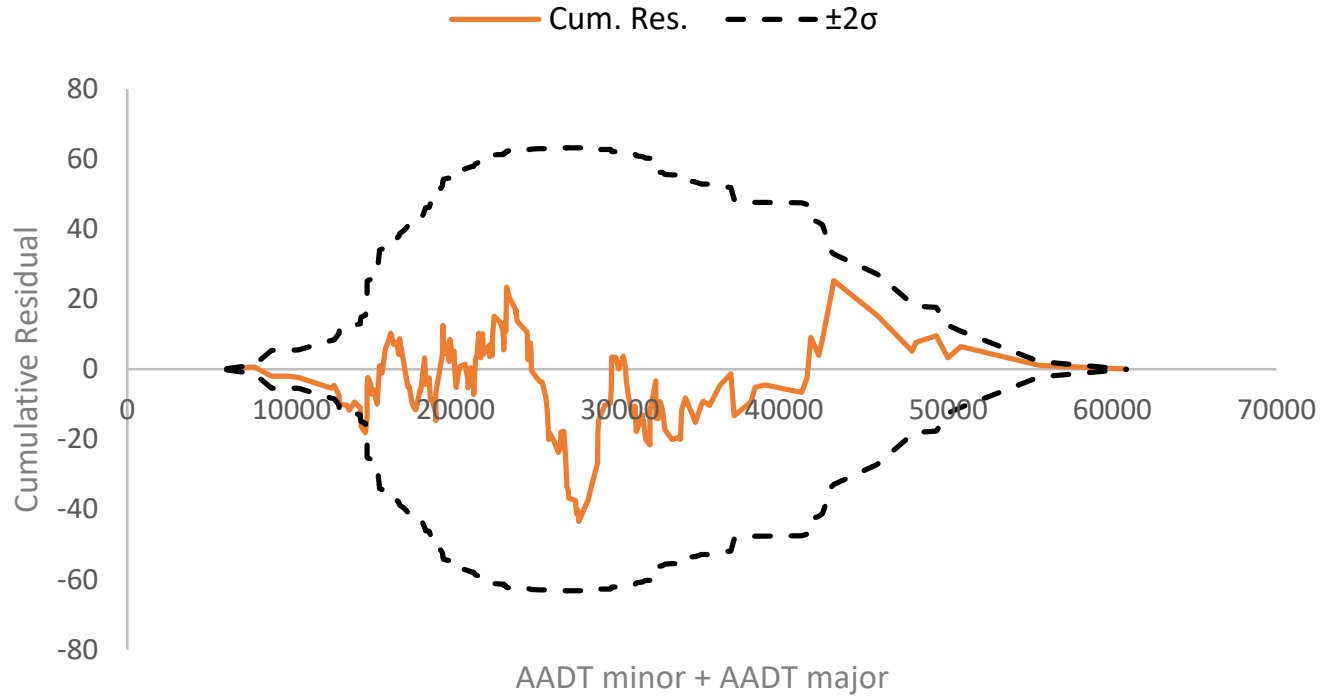


Figure A18. CURE Plot for fatal and injury crashes for urban signalized intersections as a function of total AADT.

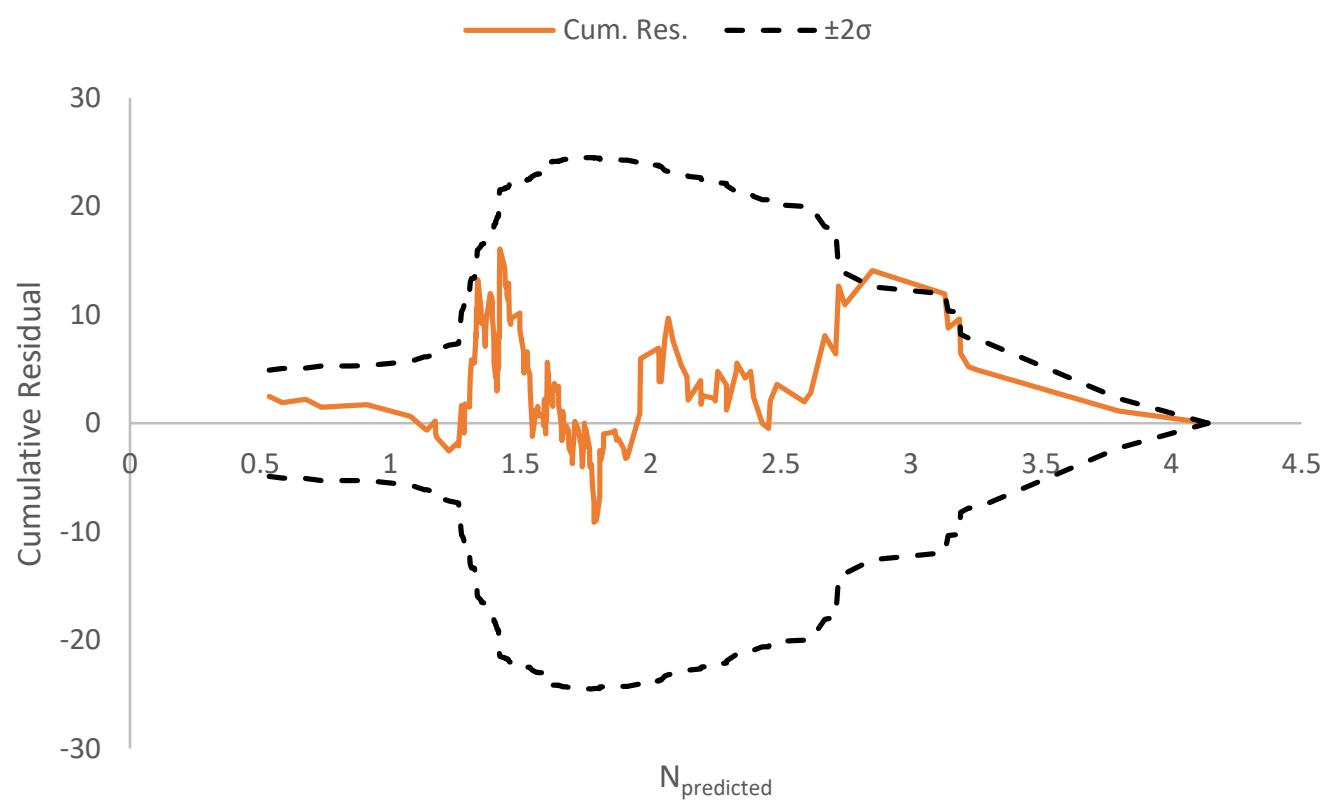

Figure A19. CURE Plot type A injury crashes for urban signalized intersections as a function of $\mathbf{N}_{\text {predicted. }}$

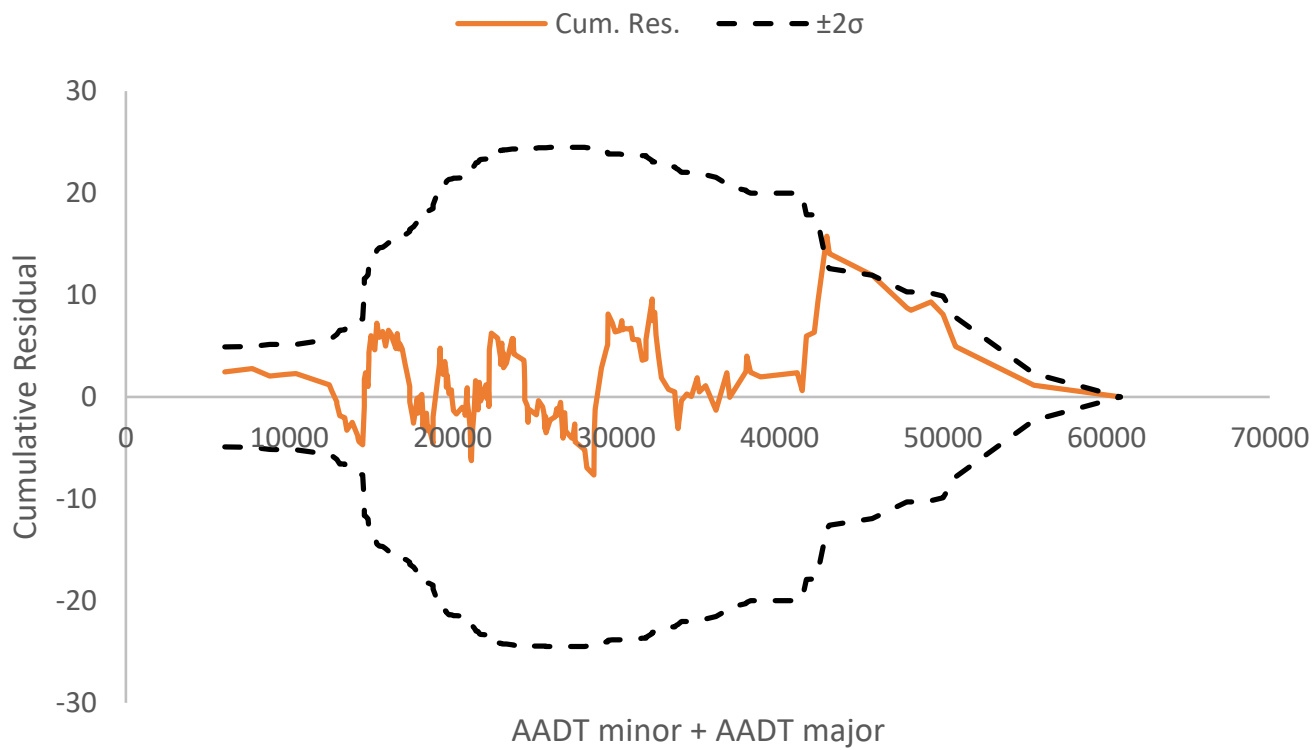

Figure A20. CURE Plot for Type A injury crashes for urban signalized intersections as a function of total AADT. 


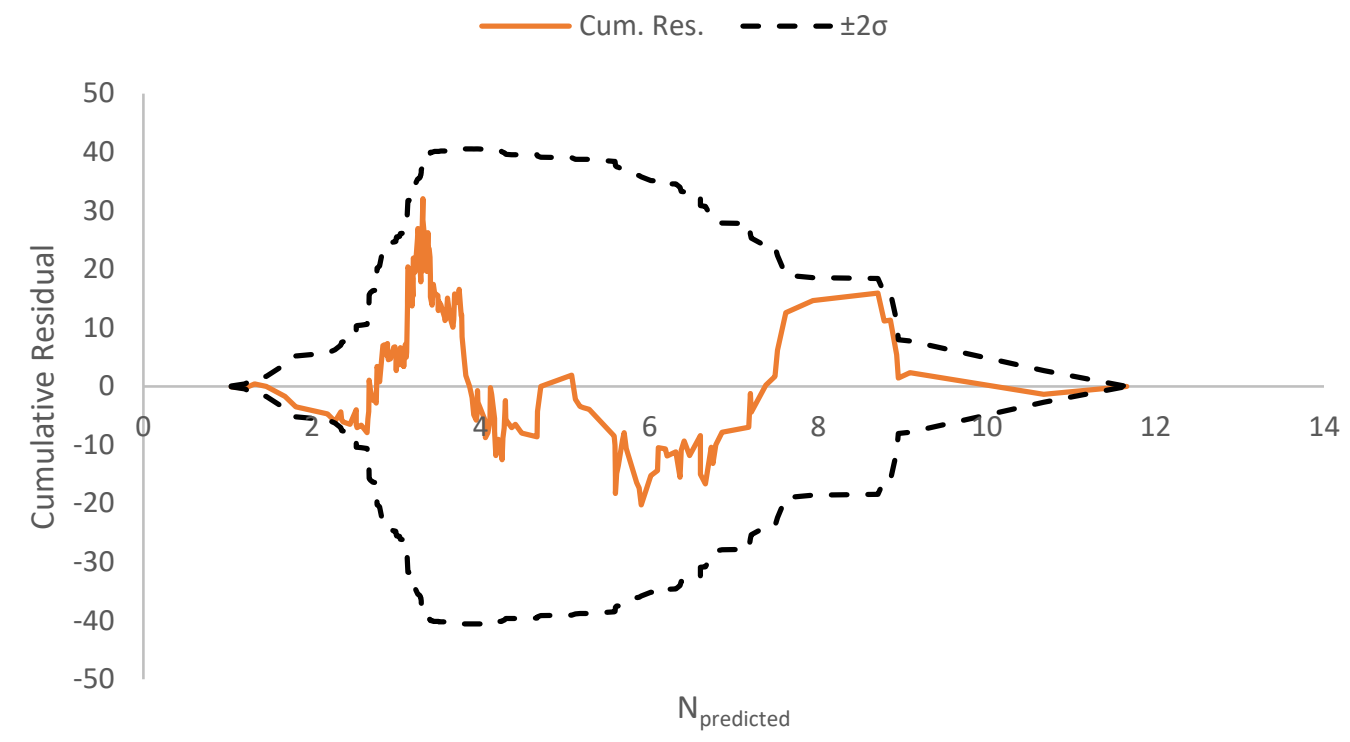

Figure A21. CURE Plot for Type B injury crashes for urban signalized intersections as a function of $\mathbf{N}_{\text {predicted. }}$

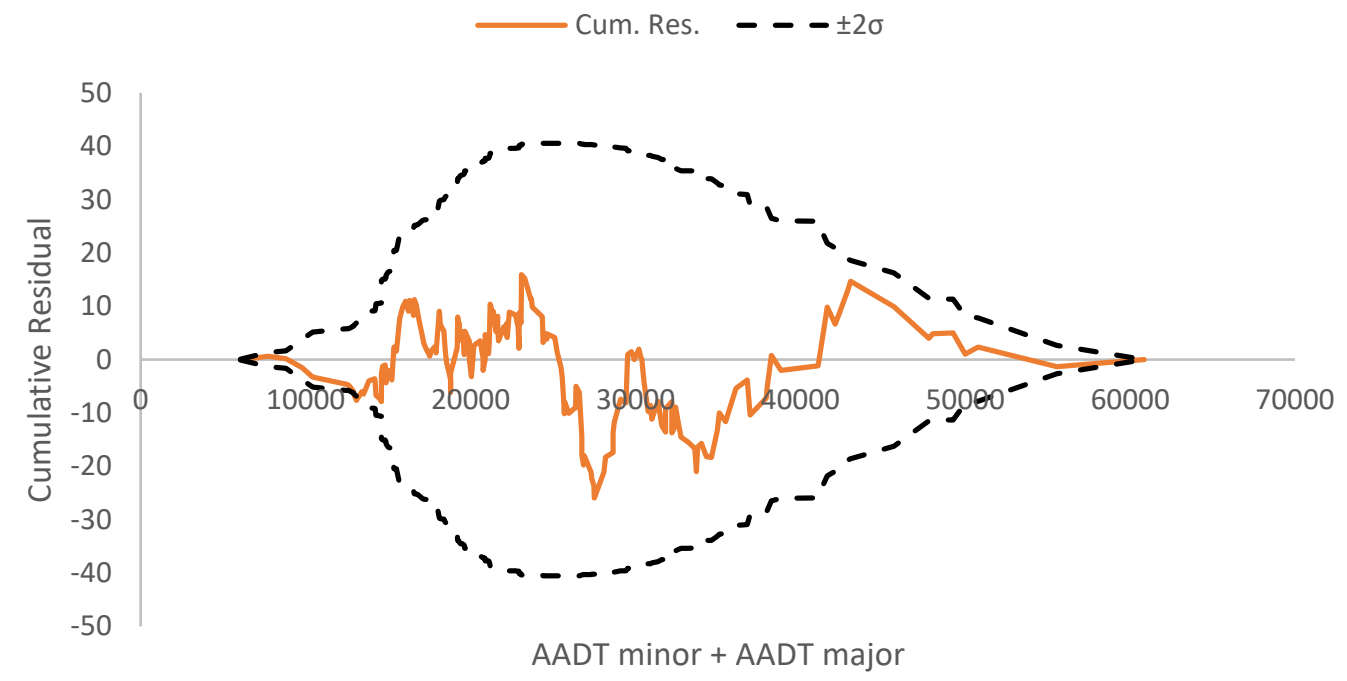

Figure A22. CURE Plot for Type B injury crashes for urban signalized intersections as a function of total AADT. 


\section{APPENDIX B}

Table B1 below presents the list of all 199 intersections utilized in the calibration of all SPFs.

Table B1 List of Four-Legged Intersections Utilized in Calibration

\begin{tabular}{|c|c|c|c|c|c|}
\hline City & Road & Road & City & Road & Road \\
\hline Springfield & 11th St & STANFORD AV & Springfield & 9TH ST & NORTH GRAND AV \\
\hline Springfield & 11th St & ASH ST & Springfield & 9TH ST & CONVERSE AV \\
\hline Springfield & 11th St & SOUTH GRAND AV & Springfield & BISSELL RD & DIRKSEN PKWY \\
\hline Springfield & 11th St & COOK ST & Springfield & BRUNS LN & JEFFERSON ST \\
\hline Springfield & 11th St & JEFFERSON ST & Springfield & CHATHAM RD & OLD CHATHAM RD \\
\hline Springfield & 11th St & MADISON ST & Springfield & CHATHAM RD & LAUREL ST \\
\hline Springfield & 11th St & CONVERSE AV & Springfield & CHATHAM RD & LAWRENCE AV \\
\hline Springfield & 19TH ST & NORTH GRAND AV & Springfield & CHATHAM RD & MONROE ST \\
\hline Springfield & 5TH ST & ASH ST & Springfield & CHATHAM RD & WASHINGTON ST \\
\hline Springfield & 5TH ST & LAUREL ST & Springfield & CIDER MILL LN & VETERANS PKWY \\
\hline Springfield & 5TH ST & SOUTH GRAND AV & Springfield & CLEAR LAKE AV & DIRKSEN PKWY \\
\hline Springfield & 5TH ST & LAWRENCE AV & Springfield & COOK ST & DIRKSEN PKWY \\
\hline Springfield & 5TH ST & COOK ST & Springfield & DIRKSEN PKWY & RIDGE AV \\
\hline Springfield & 5TH ST & CAPITOL AV & Springfield & DIRKSEN PKWY & SANGAMON AV \\
\hline Springfield & 5TH ST & MONROE ST & Springfield & GREENBRIAR DR & VETERANS PKWY \\
\hline Springfield & 5TH ST & JEFFERSON ST & Springfield & J DAVID JONES & NORTH GRAND AV \\
\hline Springfield & 5TH ST & MADISON ST & Springfield & J DAVID JONES & VETERANS PKWY \\
\hline Springfield & 5TH ST & CARPENTER ST & Springfield & JEFFERSON ST & VETERANS PKWY \\
\hline Springfield & 5TH ST & NORTH GRAND AV & Springfield & JEFFERSON ST & WALNUT ST \\
\hline Springfield & 6TH ST & ASH ST & Springfield & LAWRENCE AV & VETERANS PKWY \\
\hline Springfield & 6TH ST & LAUREL ST & Springfield & LAWRENCE AV & WALNUT ST \\
\hline Springfield & 6TH ST & SOUTH GRAND AV & Springfield & MONROE ST & VETERANS PKWY \\
\hline Springfield & 6TH ST & LAWRENCE AV & Springfield & MONROE ST & WALNUT ST \\
\hline Springfield & 6TH ST & COOK ST & Springfield & SOUTH GRAND AV & DIRKSEN PKWY \\
\hline Springfield & 6TH ST & CAPITOL AV & Springfield & VETERANS PKWY & WASHINGTON ST \\
\hline Springfield & 6TH ST & MONROE ST & Springfield & WALNUT ST & WASHINGTON ST \\
\hline Springfield & 6TH ST & JEFFERSON ST & NB & AIRPORT RD & G.E. ROAD \\
\hline Springfield & 6TH ST & MADISON ST & NB & BOWLES ST & GREGORY ST \\
\hline Springfield & 6TH ST & CARPENTER ST & NB & CENTER ST & WOOD ST \\
\hline Springfield & 6TH ST & NORTH GRAND AV & NB & CENTER ST & MACARTHUR AVE \\
\hline Springfield & 9TH ST & LAUREL ST & NB & CENTER ST & OAKLAND AVE \\
\hline Springfield & 9TH ST & SOUTH GRAND AV & NB & CENTER ST & LOCUST ST \\
\hline Springfield & 9TH ST & COOK ST & NB & CENTER ST & EMPIRE ST \\
\hline Springfield & 9TH ST & JEFFERSON ST & NB & CENTER ST & EMERSON \\
\hline Springfield & 9TH ST & MADISON ST & NB & COLLEGE AVE & LINDEN ST \\
\hline Springfield & 9TH ST & CARPENTER ST & NB & COLLEGE AVE & TOWANDA AVE \\
\hline
\end{tabular}


Table B1 List of Four-Legged Intersections Utilized in Calibration (cont.)

\begin{tabular}{|c|c|c|c|c|c|}
\hline City & Road & Road & City & Road & Road \\
\hline NB & COLLEGE AVE & VETERANS PKWY & Peoria & W PIONEER PKWY & UNIVERSITY ST. \\
\hline NB & EAST ST & MAIN ST & Peoria & WAR MEMORIAL DR & WILLOW KNOLLS \\
\hline NB & EAST ST & WASHINGTON ST & Peoria & WAR MEMORIAL DR & ALLEN RD \\
\hline NB & EAST ST & LOCUST ST & Peoria & WAR MEMORIAL DR & UNIVERSITY ST. \\
\hline NB & EMERSON & MAIN ST & Peoria & WAR MEMORIAL DR & SHERIDAN RD \\
\hline NB & EMERSON & FAIRWAY DR & Peoria & WAR MEMORIAL DR & PROSPECT ROAD \\
\hline NB & EMPIRE ST & MAIN ST & $\mathrm{CU}$ & BRADLEY AVE & MATTIS AVE \\
\hline NB & EMPIRE ST & HERSHEY RD & $\mathrm{CU}$ & BRADLEY AVE & PROSPECT AVE \\
\hline NB & FT JESSE RD & TOWANDA AVE & $\mathrm{CU}$ & BRADLEY AVE & NEIL ST \\
\hline NB & FT JESSE RD & VETERANS PKWY & $\mathrm{CU}$ & BRADLEY AVE & LINCOLN AVE \\
\hline NB & G.E. ROAD & HERSHEY RD & $\mathrm{CU}$ & CHURCH ST & PROSPECT AVE \\
\hline NB & HERSHEY RD & IRELAND GROVE & $\mathrm{CU}$ & CUNNINGHAM AVE & UNIVERSITY AVE \\
\hline NB & HERSHEY RD & OAKLAND AVE & $\mathrm{CU}$ & CUNNINGHAM AVE & KERR AVE \\
\hline NB & HERSHEY RD & WASHINGTON & $\mathrm{CU}$ & CUNNINGHAM AVE & PERKINS RD \\
\hline NB & LINDEN ST & VERNON AVE & $\mathrm{CU}$ & DUNCAN RD (900 E) & WINDSOR RD \\
\hline NB & LINDEN ST & MULBERRY ST & $\mathrm{CU}$ & DUNCAN RD (900 E) & KIRBY AVE \\
\hline NB & LINDEN ST & RAAB RD & $\mathrm{CU}$ & FAIRVIEW AVE & LINCOLN AVE \\
\hline NB & MACARTHUR AVE & MAIN ST & $\mathrm{CU}$ & FIRST ST & WINDSOR RD \\
\hline NB & MAIN ST & WOOD ST & $\mathrm{CU}$ & FIRST ST & KIRBY AVE \\
\hline NB & MAIN ST & OAKLAND AVE & $\mathrm{CU}$ & FIRST ST & SPRINGFIELD AVE \\
\hline NB & MAIN ST & VIRGINIA AVE & $\mathrm{CU}$ & FLORIDA AVE & LINCOLN AVE \\
\hline NB & MAIN ST & ORLANDO AVE & $\mathrm{CU}$ & FOURTH ST & SPRINGFIELD AVE \\
\hline NB & MAIN ST & RAAB RD & $\mathrm{CU}$ & GREEN ST & PROSPECT AVE \\
\hline NB & PARKWAY PLAZA DR & VETERANS PKWY & $\mathrm{CU}$ & GREEN ST & NEIL ST \\
\hline NB & SHELBOURNE DR & TOWANDA AVE & $\mathrm{CU}$ & GREEN ST & FIRST ST \\
\hline NB & STATE ST & TOWANDA & $\mathrm{CU}$ & GREEN ST & FOURTH ST \\
\hline NB & TOWANDA AVE & VERNON AVE & $\mathrm{CU}$ & GREEN ST & LINCOLN AVE \\
\hline Peoria & ALLEN RD & WILLOW KNOLLS & $\mathrm{CU}$ & ILLINOIS ST & LINCOLN AVE \\
\hline Peoria & ALLEN RD & TOWN LINE RD & $\mathrm{CU}$ & JOHN ST & MATTIS AVE \\
\hline Peoria & COLUMBIA TERR & UNIVERSITY ST. & $\mathrm{CU}$ & KIRBY AVE & PROSPECT AVE \\
\hline Peoria & E GLEN AVE & W GLEN AVE & $\mathrm{CU}$ & KIRBY AVE & FOURTH ST \\
\hline Peoria & ELAINE AVE & KNOXVILLE AVE & $\mathrm{CU}$ & LINCOLN AVE & PENNSYLVANIA AVE \\
\hline Peoria & GLEN AVE & E GLEN AVE & $\mathrm{CU}$ & LINCOLN AVE & SPRINGFIELD AVE \\
\hline Peoria & KNOXVILLE AVE & DETWEILLER DR. & $\mathrm{CU}$ & LINCOLN AVE & UNIVERSITY AVE \\
\hline Peoria & LAKE AVE & SHERIDAN RD & $\mathrm{CU}$ & MATTIS AVE & WINDSOR RD \\
\hline Peoria & LAKE AVE & KNOXVILLE AVE & $\mathrm{CU}$ & MATTIS AVE & KIRBY AVE \\
\hline Peoria & LAKE AVE & PROSPECT ROAD & $\mathrm{CU}$ & MATTIS AVE & BLOOMINGTON RD \\
\hline
\end{tabular}


Table B1 List of Four-Legged Intersections Utilized in Calibration (cont.)

\begin{tabular}{ccc|ccc}
\hline City & Road & Road & City & Road & Road \\
Peoria & MAIN & UNIVERSITY ST. & Peoria & W FORREST HILL & KNOXVILLE AVE \\
Peoria & MCCLURE AVE & KNOXVILLE AVE & CU & NEIL ST & SPRINGFIELD AVE \\
Peoria & NEBRASKA AVE & UNIVERSITY ST. & CU & UNIVERSITY AVE & PROSPECT AVE \\
Peoria & NEBRASKA AVE & KNOXVILLE AVE & CU & UNIVERSITY AVE & NEIL ST \\
Peoria & NORTHMOOR RD & UNIVERSITY ST. & CU & UNIVERSITY AVE & FIRST ST \\
Peoria & SHERIDAN RD & MAIN & CU & UNIVERSITY AVE & FOURTH ST \\
Peoria & SHERIDAN RD & MCCLURE AVE & CU & VINE ST & MAIN ST \\
Peoria & SHERIDAN RD & W GLEN AVE & CU & PROSPECT AVE & WINDSOR RD \\
Peoria & SHERIDAN RD & NORTHMOOR RD & CU & SPRINGFIELD AVE & MATTIS AVE \\
Peoria & UNIVERSITY ST. & W GLEN AVE & CU & SPRINGFIELD AVE & PROSPECT AVE \\
Peoria & W FORREST HILL & SHERIDAN RD & CU & UNIVERSITY AVE & MATTIS AVE \\
\hline
\end{tabular}

$\mathrm{NB}=$ Normal-Bloomington, $\mathrm{CU}=$ Champaign-Urbana 
Table B2 List of Three-Legged Intersections Utilized in Calibration (cont.)

\begin{tabular}{|c|c|c|}
\hline City & Road & Road \\
\hline Springfield & $11 \mathrm{TH}$ ST & STEVENSON DR \\
\hline Springfield & ARCHER ELEV RD & WABASH AV \\
\hline Springfield & ARROWHEAD DR & SANGAMON AV \\
\hline Springfield & BROWNING RD & TAINTOR RD \\
\hline Springfield & CHATHAM RD & ILES AV \\
\hline Springfield & CHATHAM RD & OLD JACKSONVILLE RD \\
\hline Springfield & CLEAR LAKE AV & MILTON AV \\
\hline Springfield & DIRKSEN PKWY & PEORIA RD \\
\hline Springfield & DRAWBRIDGE RD & WABASH AV \\
\hline Springfield & IRON BRIDGE RD & WOODSIDE RD \\
\hline Springfield & KOKE MILL RD & WASHINGTON ST \\
\hline Springfield & KOKE MILL RD & WASHINGTON ST \\
\hline Springfield & MONROE ST & MOUNTCASTLE RD \\
\hline Springfield & OLD CHATHAM RD & WOODSIDE RD \\
\hline Springfield & SOUTH GRAND AV & WALNUT ST \\
\hline NB & AIRPORT RD & EMPIRE \\
\hline NB & BROWN ST & BROWN ST \\
\hline NB & BUNN ST & OAKLAND AVE \\
\hline NB & COLLEGE AVE & GRANDVIEW DR \\
\hline NB & EAST ST & MONROE ST \\
\hline NB & EAST ST & MARKET ST \\
\hline NB & HANNAH ST & OAKLAND AVE \\
\hline NB & HERSHEY RD & LINCOLN ST \\
\hline NB & IRELAND GROVE & VETERANS PKWY \\
\hline NB & MARKET ST & MORRIS AVE \\
\hline Peoria & FARMINGTON RD & STERLING AVE \\
\hline Peoria & FARMINGTON RD & MAIN \\
\hline $\mathrm{CU}$ & BRADLEY AVE & COUNTRY FAIR DR \\
\hline CU & BURWASH AVE & DUNLAP AVE \\
\hline $\mathrm{CU}$ & INTERSTATE DR & MATTIS AVE \\
\hline $\mathrm{CU}$ & LINCOLN AVE & NEVADA ST \\
\hline
\end{tabular}

$\mathrm{NB}=$ Normal-Bloomington, $\mathrm{CU}=$ Champaign-Urbana 


\section{APPENDIX C}

The Table C1 below presents the pedestrian volumes for the Champaign-Urbana intersections utilized to determine the level of pedestrian activity for the SPF calibration. Although the year of the volumes presented vary from 2010 to 2016, the vast majority are volumes from the year 2012.

Table C1. Pedestrian Volumes in Urbana-Champaign Intersections

\begin{tabular}{|c|c|c|c|}
\hline NS Roadway & EW Roadway & Ped. Volumes & Ped Vol/0.28 \\
\hline Duncan Rd & Windsor Rd & 10 & 36 \\
\hline Mattis Ave & Bloomington $\mathrm{Rd}$ & 8 & 29 \\
\hline Mattis Ave & John St & 224 & 800 \\
\hline Mattis Ave & Kirby Ave & 14 & 50 \\
\hline Mattis Ave & Windsor Rd & 5 & 18 \\
\hline Prospect Ave & Church St & 91 & 325 \\
\hline Prospect Ave & University Ave & 2 & 7 \\
\hline Prospect Ave & Windsor Rd & 11 & 39 \\
\hline Neil St & Windsor Rd & 17 & 61 \\
\hline Neil St & Fox Dr/ St. Mary's Rd & 29 & 104 \\
\hline Neil St & Kirby Ave & 125 & 446 \\
\hline Neil St & Hessel Blvd/Stadium Dr & 131 & 468 \\
\hline Neil St & Bradley Ave & 8 & 29 \\
\hline Neil St & University Ave & 592 & 2114 \\
\hline Neil St & Springfield Ave & 109 & 389 \\
\hline Neil St & Green St & 300 & 1071 \\
\hline Walnut St & University Ave & 757 & 2704 \\
\hline First St & University Ave & 161 & 575 \\
\hline First St & Springfield Ave & 243 & 868 \\
\hline First St & Green St & 453 & 1618 \\
\hline First St & Kirby Ave & 71 & 254 \\
\hline Fourth St & Springfield Ave & 590 & 2107 \\
\hline Fourth St & University Ave & 53 & 189 \\
\hline Fourth St & Kirby Ave & 246 & 879 \\
\hline Lincoln Ave & Bradley Ave & 209 & 746 \\
\hline Lincoln Ave & Fairview Ave & 38 & 136 \\
\hline Lincoln Ave & University Ave & 91 & 325 \\
\hline Lincoln Ave & Springfield Ave & 161 & 575 \\
\hline Lincoln Ave & Green St & 485 & 1732 \\
\hline Lincoln Ave & Illinois St & 718 & 2564 \\
\hline Lincoln Ave & Pennsylvania Ave & 0 & 0 \\
\hline Lincoln Ave & Florida Ave & 336 & 1200 \\
\hline \multirow[t]{2}{*}{ Vine St } & Main St & 433 & 1546 \\
\hline & & Avg $=$ & 727 \\
\hline
\end{tabular}




\section{APPENDIX D}

The following tables present the breakdown of crashes for both the intersections and segments along the corridor. The segments were enumerated from 1 through 5 representing their order from North to South. For instance, segment 1 is the north most segment between Stadium Dr. and Kirby Ave. Also, it is worth mentioning all crashes outside of the $250 \mathrm{ft}$ range from the center of each intersection was classified as segment intersection. Thus, even if crashes occurred on a business driveway or an unsignalized intersection in between the project intersections, they were still considered "segment crashes."

Table D1. Corridor Total Crashes per Year

\begin{tabular}{|c|c|c|c|c|c|c|c|}
\hline \multirow[b]{2}{*}{ Major road } & \multirow[b]{2}{*}{ Minor Road } & \multicolumn{3}{|c|}{ Before (36 months) } & \multicolumn{2}{|c|}{ After (18 months) } & \multirow[b]{2}{*}{ Total } \\
\hline & & 2012 & 2013 & 2014 & $\begin{array}{c}\text { May2015- } \\
\text { Dec2015 }\end{array}$ & $\begin{array}{l}\text { Jan2016- } \\
\text { Oct2016 }\end{array}$ & \\
\hline Neil St. & Stadium Dr. & 6 & 3 & 7 & 3 & 2 & 21 \\
\hline \multicolumn{2}{|c|}{ Segment 1} & 6 & 3 & 3 & 3 & 1 & 16 \\
\hline Neil St. & Kirby Ave. & 22 & 17 & 15 & 13 & 14 & 81 \\
\hline \multicolumn{2}{|c|}{ Segment 2} & 3 & 1 & 0 & 4 & 1 & 9 \\
\hline Neil St. & St. Mary's Rd. & 3 & 4 & 4 & 6 & 6 & 23 \\
\hline \multicolumn{2}{|c|}{ Segment 3} & 1 & 2 & 4 & 4 & 3 & 14 \\
\hline Neil St. & Devonshire Dr. & 5 & 3 & 4 & 5 & 2 & 19 \\
\hline \multicolumn{2}{|c|}{ Segment 4} & 0 & 0 & 0 & 1 & 0 & 1 \\
\hline Neil St. & Knollwood St. & 3 & 0 & 5 & 3 & 1 & 12 \\
\hline \multicolumn{2}{|c|}{ Segment 5} & 0 & 1 & 1 & 1 & 0 & 3 \\
\hline \multirow[t]{2}{*}{ Neil St. } & Windsor Rd. & 9 & 15 & 9 & 6 & 7 & 46 \\
\hline & Corridor (Sum) & 58 & 49 & 52 & 49 & 37 & 245 \\
\hline
\end{tabular}

Table D2. Intersections Total Crashes per Year

\begin{tabular}{|c|c|c|c|c|c|c|c|}
\hline \multicolumn{2}{|c|}{} & \multicolumn{3}{|c|}{ Before (36 months) } & After (18 months) & \\
\hline Major road & Minor Road & $\mathbf{2 0 1 2}$ & $\mathbf{2 0 1 3}$ & $\mathbf{2 0 1 4}$ & $\begin{array}{c}\text { May2015- } \\
\text { Dec2015 }\end{array}$ & $\begin{array}{c}\text { Jan2016- } \\
\text { Oct2016 }\end{array}$ & Total \\
\hline Neil St. & Stadium Dr. & 6 & 3 & 7 & 3 & 2 & 21 \\
\hline Neil St. & Kirby Ave. & 22 & 17 & 15 & 13 & 14 & 81 \\
\hline Neil St. & St. Mary's Rd. & 3 & 4 & 4 & 6 & 6 & 23 \\
\hline Neil St. & Devonshire Dr. & 5 & 3 & 4 & 5 & 2 & 19 \\
\hline Neil St. & Knollwood St. & 3 & 0 & 5 & 3 & 1 & 12 \\
\hline Neil St. & Windsor Rd. & 9 & 15 & 9 & 6 & 7 & 46 \\
\hline & Sum & 48 & 42 & 44 & 36 & 32 & 202 \\
\hline
\end{tabular}


Table D3. Segments Total Crashes per Year

\begin{tabular}{|c|c|c|c|c|c|c|}
\hline & \multicolumn{3}{|c|}{ Before (36 months) } & \multicolumn{2}{|c|}{ After (18 months) } & \\
\hline Segment & $\mathbf{2 0 1 2}$ & $\mathbf{2 0 1 3}$ & $\mathbf{2 0 1 4}$ & $\begin{array}{c}\text { May2015- } \\
\text { Dec2015 }\end{array}$ & $\begin{array}{c}\text { Jan2016- } \\
\text { Oct2016 }\end{array}$ & Total \\
\hline 1 & 6 & 3 & 3 & 3 & 1 & 16 \\
\hline 2 & 3 & 1 & 0 & 4 & 1 & 9 \\
\hline 3 & 1 & 2 & 4 & 4 & 3 & 14 \\
\hline 4 & 0 & 0 & 0 & 1 & 0 & 1 \\
\hline 5 & 0 & 1 & 1 & 1 & 0 & 3 \\
\hline Sum & 10 & 7 & 8 & 13 & 5 & 43 \\
\hline
\end{tabular}

Table D4. Corridor Fatal and Injury Crashes per Year

\begin{tabular}{|c|c|c|c|c|c|c|c|}
\hline \multirow[b]{2}{*}{ Major road } & \multirow[b]{2}{*}{ Minor Road } & \multicolumn{3}{|c|}{ Before (36 months) } & \multicolumn{2}{|c|}{ After (18 months) } & \multirow[b]{2}{*}{ Tota } \\
\hline & & 2012 & 2013 & 2014 & $\begin{array}{c}\text { May2015- } \\
\text { Dec2015 }\end{array}$ & $\begin{array}{c}\text { Jan2016- } \\
\text { Oct2016 }\end{array}$ & \\
\hline Neil St. & Stadium Dr. & 1 & 2 & 1 & 0 & 0 & 4 \\
\hline \multicolumn{2}{|c|}{ Segment 1} & 0 & 0 & 2 & 1 & 0 & 3 \\
\hline Neil St. & Kirby Ave. & 6 & 4 & 6 & 2 & 1 & 19 \\
\hline \multicolumn{2}{|c|}{ Segment 2} & 0 & 0 & 0 & 0 & 0 & 0 \\
\hline Neil St. & St. Mary's Rd. & 1 & 1 & 2 & 4 & 0 & 8 \\
\hline \multicolumn{2}{|c|}{ Segment 3} & 1 & 0 & 2 & 0 & 1 & 4 \\
\hline Neil St. & Devonshire Dr. & 1 & 1 & 0 & 1 & 0 & 3 \\
\hline \multicolumn{2}{|c|}{ Segment 4} & 0 & 0 & 0 & 0 & 0 & 0 \\
\hline Neil St. & Knollwood St. & 0 & 0 & 2 & 0 & 1 & 3 \\
\hline \multicolumn{2}{|c|}{ Segment 5} & 0 & 0 & 1 & 0 & 0 & 1 \\
\hline \multirow[t]{2}{*}{ Neil St. } & Windsor Rd. & 4 & 0 & 5 & 1 & 2 & 12 \\
\hline & Corridor (Sum) & 14 & 8 & 21 & 9 & 5 & 57 \\
\hline
\end{tabular}


Table D5. Intersections Fatal and Injury Crashes per Year

\begin{tabular}{|c|c|c|c|c|c|c|c|}
\hline \multicolumn{2}{|c|}{} & \multicolumn{3}{|c|}{ Before (36 months) } & After (18 months) & \\
\hline Major road & Minor Road & $\mathbf{2 0 1 2}$ & $\mathbf{2 0 1 3}$ & $\mathbf{2 0 1 4}$ & $\begin{array}{c}\text { May2015- } \\
\text { Dec2015 }\end{array}$ & $\begin{array}{c}\text { Jan2016- } \\
\text { Oct2016 }\end{array}$ & Total \\
\hline Neil St. & Stadium Dr. & 1 & 2 & 1 & 0 & 0 & 4 \\
\hline Neil St. & Kirby Ave. & 6 & 4 & 6 & 2 & 1 & 19 \\
\hline Neil St. & St. Mary's Rd. & 1 & 1 & 2 & 4 & 0 & 8 \\
\hline Neil St. & Devonshire Dr. & 1 & 1 & 0 & 1 & 0 & 3 \\
\hline Neil St. & Knollwood St. & 0 & 0 & 2 & 0 & 1 & 3 \\
\hline Neil St. & Windsor Rd. & 4 & 0 & 5 & 1 & 2 & 12 \\
\hline & Sum & 13 & 8 & 16 & 8 & 4 & 49 \\
\hline
\end{tabular}

Table D6. Segments Fatal and Injury Crashes per Year

\begin{tabular}{|c|c|c|c|c|c|c|}
\hline & \multicolumn{3}{|c|}{ Before (36 months) } & \multicolumn{2}{|c|}{ After (18 months) } & \\
\hline Segment & $\mathbf{2 0 1 2}$ & $\mathbf{2 0 1 3}$ & $\mathbf{2 0 1 4}$ & $\begin{array}{c}\text { May2015- } \\
\text { Dec2015 }\end{array}$ & $\begin{array}{c}\text { Jan2016- } \\
\text { Oct2016 }\end{array}$ & Total \\
\hline 1 & 0 & 0 & 2 & 1 & 0 & 3 \\
\hline 2 & 0 & 0 & 0 & 0 & 0 & 0 \\
\hline 3 & 1 & 0 & 2 & 0 & 1 & 4 \\
\hline 4 & 0 & 0 & 0 & 0 & 0 & 0 \\
\hline 5 & 0 & 0 & 1 & 0 & 0 & 1 \\
\hline Sum & 1 & 0 & 5 & 1 & 1 & 8 \\
\hline
\end{tabular}


Table D7. Corridor PDO Crashes per Year

\begin{tabular}{|c|c|c|c|c|c|c|c|}
\hline \multirow[b]{2}{*}{ Major road } & \multirow[b]{2}{*}{ Minor Road } & \multicolumn{3}{|c|}{ Before (36 months) } & \multicolumn{2}{|c|}{ After (18 months) } & \multirow[b]{2}{*}{ Total } \\
\hline & & 2012 & 2013 & 2014 & $\begin{array}{c}\text { May2015- } \\
\text { Dec2015 }\end{array}$ & $\begin{array}{l}\text { Jan2016- } \\
\text { Oct2016 }\end{array}$ & \\
\hline Neil St. & Stadium Dr. & 5 & 1 & 6 & 3 & 2 & 17 \\
\hline \multicolumn{2}{|c|}{ Segment 1} & 6 & 3 & 1 & 2 & 1 & 13 \\
\hline Neil St. & Kirby Ave. & 16 & 13 & 9 & 11 & 13 & 62 \\
\hline \multicolumn{2}{|c|}{ Segment 2} & 3 & 1 & 0 & 4 & 1 & 9 \\
\hline Neil St. & St. Mary's Rd. & 2 & 3 & 2 & 2 & 6 & 15 \\
\hline \multicolumn{2}{|c|}{ Segment 3} & 0 & 2 & 2 & 4 & 2 & 10 \\
\hline Neil St. & Devonshire Dr. & 4 & 2 & 4 & 4 & 2 & 16 \\
\hline \multicolumn{2}{|c|}{ Segment 4} & 0 & 0 & 0 & 1 & 0 & 1 \\
\hline Neil St. & Knollwood St. & 3 & 0 & 3 & 3 & 0 & 9 \\
\hline \multicolumn{2}{|c|}{ Segment 5} & 0 & 1 & 0 & 1 & 0 & 2 \\
\hline \multirow[t]{2}{*}{ Neil St. } & Windsor Rd. & 5 & 15 & 4 & 5 & 5 & 34 \\
\hline & Corridor (Sum) & 44 & 41 & 31 & 40 & 32 & 188 \\
\hline
\end{tabular}

Table D8. Intersections PDO Crashes per Year

\begin{tabular}{|c|c|c|c|c|c|c|c|}
\hline \multicolumn{2}{|c|}{} & \multicolumn{3}{|c|}{ Before (36 months) } & After (18 months) & \\
\hline Major road & Minor Road & $\mathbf{2 0 1 2}$ & $\mathbf{2 0 1 3}$ & $\mathbf{2 0 1 4}$ & $\begin{array}{c}\text { May2015- } \\
\text { Dec2015 }\end{array}$ & $\begin{array}{c}\text { Jan2016- } \\
\text { Oct2016 }\end{array}$ & Total \\
\hline Neil St. & Stadium Dr. & 5 & 1 & 6 & 3 & 2 & 17 \\
\hline Neil St. & Kirby Ave. & 16 & 13 & 9 & 11 & 13 & 62 \\
\hline Neil St. & St. Mary's Rd. & 2 & 3 & 2 & 2 & 6 & 15 \\
\hline Neil St. & Devonshire Dr. & 4 & 2 & 4 & 4 & 2 & 16 \\
\hline Neil St. & Knollwood St. & 3 & 0 & 3 & 3 & 0 & 9 \\
\hline Neil St. & Windsor Rd. & 5 & 15 & 4 & 5 & 5 & 34 \\
\hline & Sum & 35 & 34 & 28 & 28 & 28 & 153 \\
\hline
\end{tabular}

Table D9. Segments PDO Crashes per Year

\begin{tabular}{|c|c|c|c|c|c|c|}
\hline & \multicolumn{2}{|c|}{ Before (36 months) } & \multicolumn{2}{|c|}{ After (18 months) } & \\
\hline Segment & $\mathbf{2 0 1 2}$ & $\mathbf{2 0 1 3}$ & $\mathbf{2 0 1 4}$ & $\begin{array}{c}\text { May2015- } \\
\text { Dec2015 }\end{array}$ & $\begin{array}{c}\text { Jan2016- } \\
\text { Oct2016 }\end{array}$ & Total \\
\hline 1 & 6 & 3 & 1 & 2 & 1 & 13 \\
\hline 2 & 3 & 1 & 0 & 4 & 1 & 9 \\
\hline 3 & 0 & 2 & 2 & 4 & 2 & 10 \\
\hline 4 & 0 & 0 & 0 & 1 & 0 & 1 \\
\hline 5 & 0 & 1 & 0 & 1 & 0 & 2 \\
\hline Sum & 9 & 7 & 3 & 12 & 4 & 35 \\
\hline
\end{tabular}


Table D10. Corridor Type A Injury Crashes per Year

\begin{tabular}{|c|c|c|c|c|c|c|c|}
\hline \multirow[b]{2}{*}{ Major road } & \multirow[b]{2}{*}{ Minor Road } & \multicolumn{3}{|c|}{ Before (36 months) } & \multicolumn{2}{|c|}{ After (18 months) } & \multirow[b]{2}{*}{ Total } \\
\hline & & 2012 & 2013 & 2014 & $\begin{array}{c}\text { May2015- } \\
\text { Dec2015 }\end{array}$ & $\begin{array}{l}\text { Jan2016- } \\
\text { Oct2016 }\end{array}$ & \\
\hline Neil St. & Stadium Dr. & 1 & 2 & 0 & 0 & 0 & 3 \\
\hline \multicolumn{2}{|c|}{ Segment 1} & 0 & 0 & 0 & 0 & 0 & 0 \\
\hline Neil St. & Kirby Ave. & 0 & 0 & 1 & 0 & 0 & 1 \\
\hline \multicolumn{2}{|c|}{ Segment 2} & 0 & 0 & 0 & 0 & 0 & 0 \\
\hline Neil St. & St. Mary's Rd. & 0 & 0 & 0 & 1 & 0 & 1 \\
\hline \multicolumn{2}{|c|}{ Segment 3} & 0 & 0 & 1 & 0 & 1 & 2 \\
\hline Neil St. & Devonshire Dr. & 0 & 0 & 0 & 0 & 0 & 0 \\
\hline \multicolumn{2}{|c|}{ Segment 4} & 0 & 0 & 0 & 0 & 0 & 0 \\
\hline Neil St. & Knollwood St. & 0 & 0 & 2 & 0 & 0 & 2 \\
\hline \multicolumn{2}{|c|}{ Segment 5} & 0 & 0 & 1 & 0 & 0 & 1 \\
\hline \multirow[t]{2}{*}{ Neil St. } & Windsor Rd. & 2 & 0 & 0 & 0 & 0 & 2 \\
\hline & Corridor (Sum) & 3 & 2 & 5 & 1 & 1 & 12 \\
\hline
\end{tabular}

Table D11. Intersections Type A Injury Crashes per Year

\begin{tabular}{|c|c|c|c|c|c|c|c|}
\hline \multicolumn{2}{|c|}{} & \multicolumn{3}{|c|}{ Before (36 months) } & After (18 months) & \\
\hline Major road & Minor Road & $\mathbf{2 0 1 2}$ & $\mathbf{2 0 1 3}$ & $\mathbf{2 0 1 4}$ & $\begin{array}{c}\text { May2015- } \\
\text { Dec2015 }\end{array}$ & $\begin{array}{c}\text { Jan2016- } \\
\text { Oct2016 }\end{array}$ & Total \\
\hline Neil St. & Stadium Dr. & 1 & 2 & 0 & 0 & 0 & 3 \\
\hline Neil St. & Kirby Ave. & 0 & 0 & 1 & 0 & 0 & 1 \\
\hline Neil St. & St. Mary's Rd. & 0 & 0 & 0 & 1 & 0 & 1 \\
\hline Neil St. & Devonshire Dr. & 0 & 0 & 0 & 0 & 0 & 0 \\
\hline Neil St. & Knollwood St. & 0 & 0 & 2 & 0 & 0 & 2 \\
\hline Neil St. & Windsor Rd. & 2 & 0 & 0 & 0 & 0 & 2 \\
\hline & Sum & 3 & 2 & 3 & 1 & 0 & 9 \\
\hline
\end{tabular}

Table D12. Segments Type A Injury Crashes per Year

\begin{tabular}{|c|c|c|c|c|c|c|}
\hline & \multicolumn{2}{|c|}{ Before (36 months) } & \multicolumn{2}{c|}{ After (18 months) } & \\
\hline Segment & $\mathbf{2 0 1 2}$ & $\mathbf{2 0 1 3}$ & $\mathbf{2 0 1 4}$ & $\begin{array}{c}\text { May2015- } \\
\text { Dec2015 }\end{array}$ & $\begin{array}{c}\text { Jan2016- } \\
\text { Oct2016 }\end{array}$ & Total \\
\hline 1 & 0 & 0 & 0 & 0 & 0 & 0 \\
\hline 2 & 0 & 0 & 0 & 0 & 0 & 0 \\
\hline 3 & 0 & 0 & 1 & 0 & 1 & 2 \\
\hline 4 & 0 & 0 & 0 & 0 & 0 & 0 \\
\hline 5 & 0 & 0 & 1 & 0 & 0 & 1 \\
\hline Sum & 0 & 0 & 2 & 0 & 1 & 3 \\
\hline
\end{tabular}


Table D13. Corridor Type B Injury Crashes per Year

\begin{tabular}{|c|c|c|c|c|c|c|c|}
\hline \multirow[b]{2}{*}{ Major road } & \multirow[b]{2}{*}{ Minor Road } & \multicolumn{3}{|c|}{$\begin{array}{c}\text { Before (36 } \\
\text { months) }\end{array}$} & \multicolumn{2}{|c|}{ After (18 months) } & \multirow[b]{2}{*}{ Total } \\
\hline & & $\begin{array}{c}201 \\
2\end{array}$ & 2013 & 2014 & $\begin{array}{c}\text { May2015- } \\
\text { Dec2015 }\end{array}$ & $\begin{array}{l}\text { Jan2016- } \\
\text { Oct2016 }\end{array}$ & \\
\hline Neil St. & Stadium Dr. & 0 & 0 & 0 & 0 & 0 & 0 \\
\hline \multicolumn{2}{|c|}{ Segment 1} & 0 & 0 & 1 & 1 & 0 & 2 \\
\hline Neil St. & Kirby Ave. & 2 & 1 & 3 & 1 & 1 & 8 \\
\hline \multicolumn{2}{|c|}{ Segment 2} & 0 & 0 & 0 & 0 & 0 & 0 \\
\hline Neil St. & St. Mary's Rd. & 0 & 1 & 1 & 1 & 0 & 3 \\
\hline \multicolumn{2}{|c|}{ Segment 3} & 0 & 0 & 1 & 0 & 0 & 1 \\
\hline Neil St. & Devonshire Dr. & 0 & 0 & 0 & 1 & 0 & 1 \\
\hline \multicolumn{2}{|c|}{ Segment 4} & 0 & 0 & 0 & 0 & 0 & 0 \\
\hline Neil St. & Knollwood St. & 0 & 0 & 0 & 0 & 1 & 1 \\
\hline \multicolumn{2}{|c|}{ Segment 5} & 0 & 0 & 0 & 0 & 0 & 0 \\
\hline \multirow[t]{2}{*}{ Neil St. } & Windsor Rd. & 1 & 0 & 3 & 0 & 1 & 5 \\
\hline & Corridor (Sum) & 3 & 2 & 9 & 4 & 3 & 21 \\
\hline
\end{tabular}

Table D14. Intersections Type B Injury Crashes per Year

\begin{tabular}{|c|c|c|c|c|c|c|c|}
\hline \multicolumn{2}{|c|}{} & \multicolumn{3}{|c|}{ Before (36 months) } & After (18 months) & \\
\hline Major road & Minor Road & $\mathbf{2 0 1 2}$ & $\mathbf{2 0 1 3}$ & $\mathbf{2 0 1 4}$ & $\begin{array}{c}\text { May2015- } \\
\text { Dec2015 }\end{array}$ & $\begin{array}{c}\text { Jan2016- } \\
\text { Oct2016 }\end{array}$ & Total \\
\hline Neil St. & Stadium Dr. & 0 & 0 & 0 & 0 & 0 & 0 \\
\hline Neil St. & Kirby Ave. & 2 & 1 & 3 & 1 & 1 & 8 \\
\hline Neil St. & St. Mary's Rd. & 0 & 1 & 1 & 1 & 0 & 3 \\
\hline Neil St. & Devonshire Dr. & 0 & 0 & 0 & 1 & 0 & 1 \\
\hline Neil St. & Knollwood St. & 0 & 0 & 0 & 0 & 1 & 1 \\
\hline Neil St. & Windsor Rd. & 1 & 0 & 3 & 0 & 1 & 5 \\
\hline & Sum & 3 & 2 & 7 & 3 & 3 & 18 \\
\hline
\end{tabular}


Table D15. Segments Type B Injury Crashes per Year

\begin{tabular}{|c|c|c|c|c|c|c|}
\hline & \multicolumn{3}{|c|}{ Before (36 months) } & \multicolumn{2}{c|}{ After (18 months) } & \\
\hline Segment & $\mathbf{2 0 1 2}$ & $\mathbf{2 0 1 3}$ & $\mathbf{2 0 1 4}$ & $\begin{array}{c}\text { May2015- } \\
\text { Dec2015 }\end{array}$ & $\begin{array}{c}\text { Jan2016- } \\
\text { Oct2016 }\end{array}$ & Total \\
\hline 1 & 0 & 0 & 1 & 1 & 0 & 2 \\
\hline 2 & 0 & 0 & 0 & 0 & 0 & 0 \\
\hline 3 & 0 & 0 & 1 & 0 & 0 & 1 \\
\hline 4 & 0 & 0 & 0 & 0 & 0 & 0 \\
\hline 5 & 0 & 0 & 0 & 0 & 0 & 0 \\
\hline Sum & 0 & 0 & 2 & 1 & 0 & 3 \\
\hline
\end{tabular}

Table D16. Corridor Type C Injury Crashes per Year

\begin{tabular}{|c|c|c|c|c|c|c|c|}
\hline \multirow[b]{2}{*}{ Major road } & \multirow[b]{2}{*}{ Minor Road } & \multicolumn{3}{|c|}{ Before (36 months) } & \multicolumn{2}{|c|}{ After (18 months) } & \multirow[b]{2}{*}{ Total } \\
\hline & & 2012 & 2013 & 2014 & $\begin{array}{l}\text { May2015- } \\
\text { Dec2015 }\end{array}$ & $\begin{array}{l}\text { Jan2016- } \\
\text { Oct2016 }\end{array}$ & \\
\hline Neil St. & Stadium Dr. & 0 & 0 & 1 & 0 & 0 & 1 \\
\hline \multicolumn{2}{|c|}{ Segment 1} & 0 & 0 & 1 & 0 & 0 & 1 \\
\hline Neil St. & Kirby Ave. & 4 & 3 & 2 & 1 & 0 & 10 \\
\hline \multicolumn{2}{|c|}{ Segment 2} & 0 & 0 & 0 & 0 & 0 & 0 \\
\hline Neil St. & St. Mary's Rd. & 1 & 0 & 1 & 2 & 0 & 4 \\
\hline \multicolumn{2}{|c|}{ Segment 3} & 1 & 0 & 0 & 0 & 0 & 1 \\
\hline Neil St. & Devonshire Dr. & 1 & 1 & 0 & 0 & 0 & 2 \\
\hline \multicolumn{2}{|c|}{ Segment 4} & 0 & 0 & 0 & 0 & 0 & 0 \\
\hline Neil St. & Knollwood St. & 0 & 0 & 0 & 0 & 0 & 0 \\
\hline \multicolumn{2}{|c|}{ Segment 5} & 0 & 0 & 0 & 0 & 0 & 0 \\
\hline \multirow[t]{2}{*}{ Neil St. } & Windsor Rd. & 1 & 0 & 2 & 1 & 1 & 5 \\
\hline & Corridor (Sum) & 8 & 4 & 7 & 4 & 1 & 24 \\
\hline
\end{tabular}

Table D17. Intersections Type C Injury Crashes per Year

\begin{tabular}{|c|c|c|c|c|c|c|c|}
\hline \multicolumn{2}{|c|}{} & \multicolumn{3}{|c|}{ Before (36 months) } & After (18 months) & \\
\hline Major road & Minor Road & $\mathbf{2 0 1 2}$ & $\mathbf{2 0 1 3}$ & $\mathbf{2 0 1 4}$ & $\begin{array}{c}\text { May2015- } \\
\text { Dec2015 }\end{array}$ & $\begin{array}{c}\text { Jan2016- } \\
\text { Oct2016 }\end{array}$ & Total \\
\hline Neil St. & Stadium Dr. & 0 & 0 & 1 & 0 & 0 & 1 \\
\hline Neil St. & Kirby Ave. & 4 & 3 & 2 & 1 & 0 & 10 \\
\hline Neil St. & St. Mary's Rd. & 1 & 0 & 1 & 2 & 0 & 4 \\
\hline Neil St. & Devonshire Dr. & 1 & 1 & 0 & 0 & 0 & 2 \\
\hline Neil St. & Knollwood St. & 0 & 0 & 0 & 0 & 0 & 0 \\
\hline Neil St. & Windsor Rd. & 1 & 0 & 2 & 1 & 1 & 5 \\
\hline & Sum & 7 & 4 & 6 & 4 & 1 & 22 \\
\hline
\end{tabular}


Table D18. Segments Type C Injury Crashes per Year

\begin{tabular}{|c|c|c|c|c|c|c|}
\hline & \multicolumn{3}{|c|}{ Before (36 months) } & \multicolumn{2}{c|}{ After (18 months) } & \\
\hline Segment & $\mathbf{2 0 1 2}$ & $\mathbf{2 0 1 3}$ & $\mathbf{2 0 1 4}$ & $\begin{array}{c}\text { May2015- } \\
\text { Dec2015 }\end{array}$ & $\begin{array}{c}\text { Jan2016- } \\
\text { Oct2016 }\end{array}$ & Total \\
\hline 1 & 0 & 0 & 1 & 0 & 0 & 1 \\
\hline 2 & 0 & 0 & 0 & 0 & 0 & 0 \\
\hline 3 & 1 & 0 & 0 & 0 & 0 & 1 \\
\hline 4 & 0 & 0 & 0 & 0 & 0 & 0 \\
\hline 5 & 0 & 0 & 0 & 0 & 0 & 0 \\
\hline Sum & 1 & 0 & 1 & 0 & 0 & 2 \\
\hline
\end{tabular}

Table D19. Corridor Angle Crashes per Year

\begin{tabular}{|c|c|c|c|c|c|c|c|}
\hline \multirow[b]{2}{*}{ Major road } & \multirow[b]{2}{*}{ Minor Road } & \multicolumn{3}{|c|}{ Before (36 months) } & \multicolumn{2}{|c|}{ After (18 months) } & \multirow[b]{2}{*}{ Total } \\
\hline & & 2012 & 2013 & 2014 & $\begin{array}{l}\text { May2015- } \\
\text { Dec2015 }\end{array}$ & $\begin{array}{l}\text { Jan2016- } \\
\text { Oct2016 }\end{array}$ & \\
\hline Neil St. & Stadium Dr. & 1 & 0 & 1 & 0 & 0 & 2 \\
\hline \multicolumn{2}{|c|}{ Segment 1} & 1 & 0 & 0 & 0 & 0 & 1 \\
\hline Neil St. & Kirby Ave. & 3 & 4 & 1 & 2 & 3 & 13 \\
\hline \multicolumn{2}{|c|}{ Segment 2} & 0 & 0 & 0 & 0 & 0 & 0 \\
\hline Neil St. & St. Mary's Rd. & 1 & 1 & 0 & 0 & 1 & 3 \\
\hline \multicolumn{2}{|c|}{ Segment 3} & 0 & 0 & 1 & 0 & 0 & 1 \\
\hline Neil St. & Devonshire Dr. & 0 & 0 & 0 & 0 & 0 & 0 \\
\hline \multicolumn{2}{|c|}{ Segment 4} & 0 & 0 & 0 & 0 & 0 & 0 \\
\hline Neil St. & Knollwood St. & 0 & 0 & 0 & 1 & 0 & 1 \\
\hline \multicolumn{2}{|c|}{ Segment 5} & 0 & 0 & 0 & 0 & 0 & 0 \\
\hline \multirow[t]{2}{*}{ Neil St. } & Windsor Rd. & 1 & 2 & 2 & 0 & 0 & 5 \\
\hline & Corridor (Sum) & 7 & 7 & 5 & 3 & 4 & 26 \\
\hline
\end{tabular}

Table D20. Intersections Angle Crashes per Year

\begin{tabular}{|c|c|c|c|c|c|c|c|}
\hline \multicolumn{2}{|c|}{} & \multicolumn{3}{|c|}{ Before (36 months) } & After (18 months) & \\
\hline Major road & Minor Road & $\mathbf{2 0 1 2}$ & $\mathbf{2 0 1 3}$ & $\mathbf{2 0 1 4}$ & $\begin{array}{c}\text { May2015- } \\
\text { Dec2015 }\end{array}$ & $\begin{array}{c}\text { Jan2016- } \\
\text { Oct2016 }\end{array}$ & Total \\
\hline Neil St. & Stadium Dr. & 1 & 0 & 1 & 0 & 0 & 2 \\
\hline Neil St. & Kirby Ave. & 3 & 4 & 1 & 2 & 3 & 13 \\
\hline Neil St. & St. Mary's Rd. & 1 & 1 & 0 & 0 & 1 & 3 \\
\hline Neil St. & Devonshire Dr. & 0 & 0 & 0 & 0 & 0 & 0 \\
\hline Neil St. & Knollwood St. & 0 & 0 & 0 & 1 & 0 & 1 \\
\hline Neil St. & Windsor Rd. & 1 & 2 & 2 & 0 & 0 & 5 \\
\hline & Sum & 6 & 7 & 4 & 3 & 4 & 24 \\
\hline
\end{tabular}


Table D21. Segments Angle Crashes per Year

\begin{tabular}{|c|c|c|c|c|c|c|}
\hline & \multicolumn{3}{|c|}{ Before (36 months) } & \multicolumn{2}{|c|}{ After (18 months) } & \\
\hline Segment & $\mathbf{2 0 1 2}$ & $\mathbf{2 0 1 3}$ & $\mathbf{2 0 1 4}$ & $\begin{array}{c}\text { May2015- } \\
\text { Dec2015 }\end{array}$ & $\begin{array}{c}\text { Jan2016- } \\
\text { Oct2016 }\end{array}$ & Total \\
\hline 1 & 1 & 0 & 0 & 0 & 0 & 1 \\
\hline 2 & 0 & 0 & 0 & 0 & 0 & 0 \\
\hline 3 & 0 & 0 & 1 & 0 & 0 & 1 \\
\hline 4 & 0 & 0 & 0 & 0 & 0 & 0 \\
\hline 5 & 0 & 0 & 0 & 0 & 0 & 0 \\
\hline Sum & 1 & 0 & 1 & 0 & 0 & 2 \\
\hline
\end{tabular}

Table D22. Corridor Rear End Crashes per Year

\begin{tabular}{|c|c|c|c|c|c|c|c|}
\hline \multirow[b]{2}{*}{ Major road } & \multirow[b]{2}{*}{ Minor Road } & \multicolumn{3}{|c|}{ Before (36 months) } & \multicolumn{2}{|c|}{ After (18 months) } & \multirow[b]{2}{*}{ Total } \\
\hline & & 2012 & 2013 & 2014 & $\begin{array}{l}\text { May2015- } \\
\text { Dec2015 }\end{array}$ & $\begin{array}{l}\text { Jan2016- } \\
\text { Oct2016 }\end{array}$ & \\
\hline Neil St. & Stadium Dr. & 3 & 1 & 2 & 3 & 1 & 10 \\
\hline \multicolumn{2}{|c|}{ Segment 1} & 2 & 1 & 2 & 1 & 0 & 6 \\
\hline Neil St. & Kirby Ave. & 9 & 10 & 7 & 5 & 5 & 36 \\
\hline \multicolumn{2}{|c|}{ Segment 2} & 2 & 0 & 0 & 2 & 1 & 5 \\
\hline Neil St. & St. Mary's Rd. & 1 & 2 & 3 & 5 & 1 & 12 \\
\hline \multicolumn{2}{|c|}{ Segment 3} & 0 & 0 & 2 & 3 & 3 & 8 \\
\hline Neil St. & Devonshire Dr. & 3 & 2 & 4 & 2 & 2 & 13 \\
\hline \multicolumn{2}{|c|}{ Segment 4} & 0 & 0 & 0 & 0 & 0 & 0 \\
\hline Neil St. & Knollwood St. & 2 & 0 & 4 & 2 & 1 & 9 \\
\hline \multicolumn{2}{|c|}{ Segment 5} & 0 & 0 & 1 & 1 & 0 & 2 \\
\hline \multirow[t]{2}{*}{ Neil St. } & Windsor Rd. & 3 & 7 & 2 & 2 & 3 & 17 \\
\hline & Corridor (Sum) & 25 & 23 & 27 & 26 & 17 & 118 \\
\hline
\end{tabular}

Table 23. Intersections Rear End Crashes per Year

\begin{tabular}{|c|c|c|c|c|c|c|c|}
\hline \multicolumn{2}{|c|}{} & \multicolumn{3}{|c|}{ Before (36 months) } & After (18 months) & \\
\hline Major road & Minor Road & $\mathbf{2 0 1 2}$ & $\mathbf{2 0 1 3}$ & $\mathbf{2 0 1 4}$ & $\begin{array}{c}\text { May2015- } \\
\text { Dec2015 }\end{array}$ & $\begin{array}{c}\text { Jan2016- } \\
\text { Oct2016 }\end{array}$ & Total \\
\hline Neil St. & Stadium Dr. & 3 & 1 & 2 & 3 & 1 & 10 \\
\hline Neil St. & Kirby Ave. & 9 & 10 & 7 & 5 & 5 & 36 \\
\hline Neil St. & St. Mary's Rd. & 1 & 2 & 3 & 5 & 1 & 12 \\
\hline Neil St. & Devonshire Dr. & 3 & 2 & 4 & 2 & 2 & 13 \\
\hline Neil St. & Knollwood St. & 2 & 0 & 4 & 2 & 1 & 9 \\
\hline Neil St. & Windsor Rd. & 3 & 7 & 2 & 2 & 3 & 17 \\
\hline & Sum & 21 & 22 & 22 & 19 & 13 & 97 \\
\hline
\end{tabular}


Table D24. Segments Rear End Crashes per Year

\begin{tabular}{|c|c|c|c|c|c|c|}
\hline & \multicolumn{2}{|c|}{ Before (36 months) } & \multicolumn{2}{c|}{ After (18 months) } & \\
\hline Segment & $\mathbf{2 0 1 2}$ & $\mathbf{2 0 1 3}$ & $\mathbf{2 0 1 4}$ & $\begin{array}{c}\text { May2015- } \\
\text { Dec2015 }\end{array}$ & $\begin{array}{c}\text { Jan2016- } \\
\text { Oct2016 }\end{array}$ & Total \\
\hline 1 & 2 & 1 & 2 & 1 & 0 & 6 \\
\hline 2 & 2 & 0 & 0 & 2 & 1 & 5 \\
\hline 3 & 0 & 0 & 2 & 3 & 3 & 8 \\
\hline 4 & 0 & 0 & 0 & 0 & 0 & 0 \\
\hline 5 & 0 & 0 & 1 & 1 & 0 & 2 \\
\hline Sum & 4 & 1 & 5 & 7 & 4 & 21 \\
\hline
\end{tabular}

Table D25. Corridor Sideswipe Crashes per Year

\begin{tabular}{|c|c|c|c|c|c|c|c|}
\hline \multirow[b]{2}{*}{ Major road } & \multirow[b]{2}{*}{ Minor Road } & \multicolumn{3}{|c|}{ Before (36 months) } & \multicolumn{2}{|c|}{ After (18 months) } & \multirow[b]{2}{*}{ Total } \\
\hline & & 2012 & 2013 & 2014 & $\begin{array}{l}\text { May2015- } \\
\text { Dec2015 }\end{array}$ & $\begin{array}{l}\text { Jan2016- } \\
\text { Oct2016 }\end{array}$ & \\
\hline Neil St. & Stadium Dr. & 1 & 0 & 0 & 0 & 0 & 1 \\
\hline \multicolumn{2}{|c|}{ Segment 1} & 0 & 1 & 0 & 1 & 1 & 3 \\
\hline Neil St. & Kirby Ave. & 1 & 1 & 1 & 0 & 3 & 6 \\
\hline \multicolumn{2}{|c|}{ Segment 2} & 1 & 0 & 0 & 0 & 0 & 1 \\
\hline Neil St. & St. Mary's Rd. & 0 & 0 & 0 & 0 & 1 & 1 \\
\hline \multicolumn{2}{|c|}{ Segment 3} & 0 & 0 & 0 & 0 & 0 & 0 \\
\hline Neil St. & Devonshire Dr. & 1 & 1 & 0 & 0 & 0 & 2 \\
\hline \multicolumn{2}{|c|}{ Segment 4} & 0 & 0 & 0 & 0 & 1 & 1 \\
\hline Neil St. & Knollwood St. & 0 & 0 & 0 & 0 & 0 & 0 \\
\hline \multicolumn{2}{|c|}{ Segment 5} & 0 & 0 & 0 & 0 & 0 & 0 \\
\hline \multirow[t]{2}{*}{ Neil St. } & Windsor Rd. & 1 & 0 & 1 & 0 & 0 & 2 \\
\hline & Corridor (Sum) & 5 & 3 & 2 & 1 & 6 & 17 \\
\hline
\end{tabular}

Table 26. Intersections Sideswipe Crashes per Year

\begin{tabular}{|c|c|c|c|c|c|c|c|}
\hline \multicolumn{2}{|c|}{} & \multicolumn{3}{|c|}{ Before (36 months) } & \multicolumn{2}{|c|}{ After (18 months) } & \\
\hline Major road & Minor Road & $\mathbf{2 0 1 2}$ & $\mathbf{2 0 1 3}$ & $\mathbf{2 0 1 4}$ & $\begin{array}{c}\text { May2015- } \\
\text { Dec2015 }\end{array}$ & $\begin{array}{c}\text { Jan2016- } \\
\text { Oct2016 }\end{array}$ & Total \\
\hline Neil St. & Stadium Dr. & 1 & 0 & 0 & 0 & 0 & 1 \\
\hline Neil St. & Kirby Ave. & 1 & 1 & 1 & 0 & 3 & 6 \\
\hline Neil St. & St. Mary's Rd. & 0 & 0 & 0 & 0 & 1 & 1 \\
\hline Neil St. & Devonshire Dr. & 1 & 1 & 0 & 0 & 0 & 2 \\
\hline Neil St. & Knollwood St. & 0 & 0 & 0 & 0 & 0 & 0 \\
\hline Neil St. & Windsor Rd. & 1 & 0 & 1 & 0 & 0 & 2 \\
\hline & Sum & 4 & 2 & 2 & 0 & 4 & 12 \\
\hline
\end{tabular}


Table D27. Segments Sideswipe Crashes per Year

\begin{tabular}{|c|c|c|c|c|c|c|}
\hline & \multicolumn{2}{|c|}{ Before (36 months) } & \multicolumn{2}{|c|}{ After (18 months) } & \\
\hline Segment & $\mathbf{2 0 1 2}$ & $\mathbf{2 0 1 3}$ & $\mathbf{2 0 1 4}$ & $\begin{array}{c}\text { May2015- } \\
\text { Dec2015 }\end{array}$ & $\begin{array}{c}\text { Jan2016- } \\
\text { Oct2016 }\end{array}$ & Total \\
\hline 1 & 0 & 1 & 0 & 1 & 1 & 3 \\
\hline 2 & 1 & 0 & 0 & 0 & 0 & 1 \\
\hline 3 & 0 & 0 & 0 & 0 & 0 & 0 \\
\hline 4 & 0 & 0 & 0 & 0 & 1 & 1 \\
\hline 5 & 0 & 0 & 0 & 0 & 0 & 0 \\
\hline Sum & 1 & 1 & 0 & 1 & 2 & 5 \\
\hline
\end{tabular}

Table D28. Corridor Turning Crashes per Year

\begin{tabular}{|c|c|c|c|c|c|c|c|}
\hline \multirow[b]{2}{*}{ Major road } & \multirow[b]{2}{*}{ Minor Road } & \multicolumn{3}{|c|}{ Before (36 months) } & \multicolumn{2}{|c|}{ After (18 months) } & \multirow[b]{2}{*}{ Total } \\
\hline & & 2012 & 2013 & 2014 & $\begin{array}{c}\text { May2015- } \\
\text { Dec2015 }\end{array}$ & $\begin{array}{l}\text { Jan2016- } \\
\text { Oct2016 }\end{array}$ & \\
\hline Neil St. & Stadium Dr. & 1 & 2 & 3 & 0 & 0 & 6 \\
\hline \multicolumn{2}{|c|}{ Segment 1} & 3 & 1 & 0 & 1 & 1 & 6 \\
\hline Neil St. & Kirby Ave. & 6 & 2 & 4 & 4 & 2 & 18 \\
\hline \multicolumn{2}{|c|}{ Segment 2} & 0 & 1 & 0 & 2 & 0 & 3 \\
\hline Neil St. & St. Mary's Rd. & 0 & 1 & 1 & 1 & 3 & 6 \\
\hline \multicolumn{2}{|c|}{ Segment 3} & 1 & 1 & 1 & 1 & 0 & 4 \\
\hline Neil St. & Devonshire Dr. & 1 & 0 & 0 & 1 & 0 & 2 \\
\hline \multicolumn{2}{|c|}{ Segment 4} & 0 & 0 & 0 & 0 & 0 & 0 \\
\hline Neil St. & Knollwood St. & 1 & 0 & 1 & 0 & 0 & 2 \\
\hline \multicolumn{2}{|c|}{ Segment 5} & 0 & 1 & 0 & 0 & 0 & 1 \\
\hline \multirow[t]{2}{*}{ Neil St. } & Windsor Rd. & 4 & 6 & 3 & 3 & 4 & 20 \\
\hline & Corridor (Sum) & 17 & 15 & 13 & 13 & 10 & 68 \\
\hline
\end{tabular}

Table D29. Intersections Turning Crashes per Year

\begin{tabular}{|c|c|c|c|c|c|c|c|}
\hline \multicolumn{2}{|c|}{} & \multicolumn{3}{|c|}{ Before (36 months) } & After (18 months) & \\
\hline Major road & Minor Road & $\mathbf{2 0 1 2}$ & $\mathbf{2 0 1 3}$ & $\mathbf{2 0 1 4}$ & $\begin{array}{c}\text { May2015- } \\
\text { Dec2015 }\end{array}$ & $\begin{array}{c}\text { Jan2016- } \\
\text { Oct2016 }\end{array}$ & Total \\
\hline Neil St. & Stadium Dr. & 1 & 2 & 3 & 0 & 0 & 6 \\
\hline Neil St. & Kirby Ave. & 6 & 2 & 4 & 4 & 2 & 18 \\
\hline Neil St. & St. Mary's Rd. & 0 & 1 & 1 & 1 & 3 & 6 \\
\hline Neil St. & Devonshire Dr. & 1 & 0 & 0 & 1 & 0 & 2 \\
\hline Neil St. & Knollwood St. & 1 & 0 & 1 & 0 & 0 & 2 \\
\hline Neil St. & Windsor Rd. & 4 & 6 & 3 & 3 & 4 & 20 \\
\hline & Sum & 13 & 11 & 12 & 9 & 9 & 54 \\
\hline
\end{tabular}


Table D30. Segments Turning Crashes per Year

\begin{tabular}{|c|c|c|c|c|c|c|}
\hline & \multicolumn{3}{|c|}{ Before (36 months) } & \multicolumn{2}{|c|}{ After (18 months) } & \\
\hline Segment & $\mathbf{2 0 1 2}$ & $\mathbf{2 0 1 3}$ & $\mathbf{2 0 1 4}$ & $\begin{array}{c}\text { May2015- } \\
\text { Dec2015 }\end{array}$ & $\begin{array}{c}\text { Jan2016- } \\
\text { Oct2016 }\end{array}$ & Total \\
\hline 1 & 3 & 1 & 0 & 1 & 1 & 6 \\
\hline 2 & 0 & 1 & 0 & 2 & 0 & 3 \\
\hline 3 & 1 & 1 & 1 & 1 & 0 & 4 \\
\hline 4 & 0 & 0 & 0 & 0 & 0 & 0 \\
\hline 5 & 0 & 1 & 0 & 0 & 0 & 1 \\
\hline Sum & 4 & 4 & 1 & 4 & 1 & 14 \\
\hline
\end{tabular}




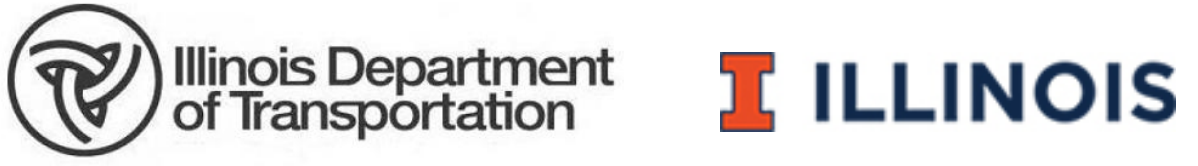

